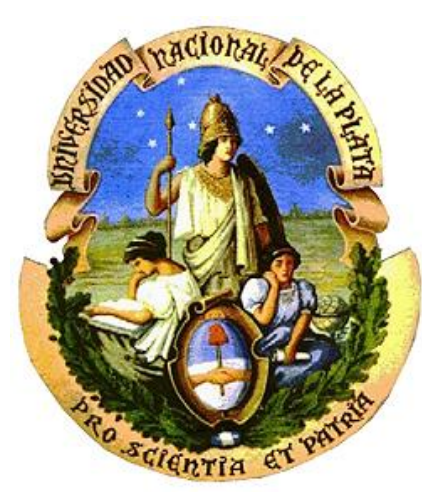

Maestría en Tecnología e Higiene de los Alimentos

(Facultad de Ciencias Agrarias y Forestales - UNLP)

\title{
Desarrollo de alimentos aptos para celíacos a base de maíz y de subproductos de la industria alimentaria
}

Ing. Agroindustrial CAROLINA DEL PILAR GIRALDO PINEDA Trabajo de tesis presentado para optar al grado académico de Magister en Tecnología e Higiene de los Alimentos

Directora: Dra. Alba Sofía del Rosario Navarro

Co-director: Dr. Diego Karim Yamul

Centro de Investigación y Desarrollo en Criotecnología de Alimentos (CIDCA)

La Plata, Argentina

2019 


\section{AGRADECIMIENTOS}

A mi padre y mi madre por la vida y a la vida por permitirme hacer lo que he querido.

A mis directores, Alba Navarro por su paciencia, escucha de cada idea surgida y su ayuda, a Karim Yamul por sus correcciones y su buen humor.

A mi gran amigo y hermano de camino en estas tierras argentinas Juan Pablo Galvis, quien siempre me animó cuando quería abandonar y siempre está.

Al CIDCA por permitirme utilizar sus instalaciones, al Instituto Nacional de la Yerba Mate por el apoyo en la investigación y a la Universidad Nacional de La Plata por brindarme la posibilidad de realizar esta tesis. 


\section{RESUMEN}

El desarrollo de alimentos que incluyan a la población celíaca y que contengan compuestos activos provenientes de fuentes naturales es una tendencia desde el punto de vista nutricional. Estos compuestos (antioxidantes, proteínas, fibras, vitaminas y minerales) están presentes también en subproductos de la industria de alimentos que pueden ser utilizados para generar alimentos con beneficios para la salud. Por ello, en este trabajo de tesis se desarrolló un snack a base de maíz con harina de lino y extracto de yerba mate y un alimento gelificado a partir del líquido de cocción del maíz con concentrado proteico de suero de leche, miel y harina de lino.

Para obtener el snack se agregó el extracto de yerba mate (1 y 3\% p/p) en el agua para la cocción del maíz y una vez obtenida la pasta de maíz se agregó la harina de lino ( 1,3 y $5 \%$ p/p en base al maíz seco). Se determinaron las condiciones óptimas de procesamiento (tiempo y temperatura de horneado, espesor, forma de agregado de ingredientes) y el producto se caracterizó a través de su color superficial $\left(L^{*}, a^{*}\right.$ y b*), contenido de humedad y actividad acuosa. Se evaluaron las modificaciones en la textura (estrés de fractura, tensión de fractura y módulo de Young) de los snacks a diferentes tiempos de almacenamiento y la microestructura se observó por microscopías electrónica de barrido y confocal láser de barrido. Se cuantificaron polifenoles, flavonoides y actividad antioxidante, se determinó la composición final del snack (humedad, proteínas, lípidos, cenizas, carbohidratos totales) y se realizó la evaluación sensorial con panelistas no entrenados.

Los resultados mostraron que un aumento en la concentración de harina de lino condujo a un mayor contenido de humedad de los snacks debido al aporte de proteínas y fibras de la harina con alta capacidad de retención de agua. Por otro lado, el efecto favorable del extracto de yerba mate al disminuir la humedad de las muestras se atribuiría a la interacción de los flavonoides del extracto con las proteínas de la harina que disminuiría los grupos hidroxilos disponibles. Además, se halló que el agregado de harina de lino aumentó la actividad acuosa de los snacks, seleccionándose el sistema con $3 \%$ de harina de lino para los siguientes ensayos por presentar menor riesgo microbiológico. La incorporación de la harina y el extracto disminuyó la luminosidad $\left(\mathrm{L}^{*}\right)$ de las muestras, con una tonalidad más intensa, aunque conservando el matiz amarillo de los snacks con sólo maíz como ingrediente. Al analizar el comportamiento de textura se observó que el agregado de harina de lino a los snacks disminuyó el estrés de fractura y el módulo elástico hasta aproximadamente la mitad del tiempo de almacenamiento para luego volver a aumentar hacia el final del almacenamiento. En cambio, el extracto de yerba mate tuvo el efecto opuesto 
aumentando el módulo elástico hasta el día 14 de almacenamiento para luego disminuir hasta valores similares a los iniciales. Los efectos combinados de la retrogradación del almidón, la migración de agua y la interacción flavonoides-proteínas serían responsables de los cambios en la textura de los snacks durante el almacenamiento. En el análisis sensorial se observó que, si bien los snacks fueron aceptados por su color y crocancia, la harina de lino y la yerba mate disminuyeron la aceptabilidad global del producto por aportar sabor amargo y astringencia. Los snacks presentaron actividad antioxidante, si bien se halló un contenido de polifenoles y flavonoides menor que en el extracto de yerba mate ya que estos compuestos permanecieron en el líquido de cocción. Finalmente, los snacks pueden considerarse aptos para celíacos ya que se detectó que no contienen prolaminas.

Con el objetivo de elaborar un postre a partir del líquido remanente de la cocción del maíz, que contiene almidón lixiviado del gránulo y los antioxidantes de la yerba mate, se agregó harina de lino $(2 \% \mathrm{p} / \mathrm{p})$, miel $(8 \% \mathrm{p} / \mathrm{p})$ y concentrado proteico de suero lácteo en diferentes concentraciones $(5,7$ y $9 \% \mathrm{p} / \mathrm{p})$ a fin de determinar el nivel necesario para lograr una textura adecuada. Las dispersiones obtenidas se gelificaron por calentamiento. Sobre los geles obtenidos se realizaron ensayos de textura y reología, así como determinaciones de color, capacidad de retención de agua, contenido de polifenoles totales, composición nutricional y evaluación sensorial.

Al analizar el comportamiento reológico y de textura se halló que el agregado de harina de lino aumentó la viscosidad aparente y rigidez de los geles, al igual que lo hizo el precalentamiento inicial de la dispersión. El aporte de almidón y de fibras de la harina de lino, como así también la interacción de éstos con los demás componentes de la muestra, contribuyeron a la formación de geles más fuertes. Además, la afinidad de los polifenoles del extracto de yerba mate por las proteínas del lactosuero influiría sobre el comportamiento viscoelástico de los geles. Por su parte, la miel tuvo un efecto opuesto a la harina al disminuir los parámetros reológicos y de textura en los geles ensayados. La capacidad de retención de agua de los geles tuvo una leve tendencia de aumento con el agregado de miel debido a su capacidad de formar puentes de hidrógeno. Se halló que el contenido de polifenoles totales disminuyó en el producto final como consecuencia de los tratamientos térmicos durante la elaboración. En cuanto a la composición final del postre formulado, su contenido de proteínas fue mayor que en un postre comercial mientras que los contenidos de lípidos y glúcidos fueron menores, denotando un perfil nutricional saludable en el producto desarrollado. Al igual que en el snack, el análisis sensorial mostró que debe optimizarse el sabor del postre incrementando el nivel de miel, teniendo en cuenta que esta modificación puede alterar la textura del producto final. 


\section{Contenido}

\section{CAPÍTULO 1}

\section{INTRODUCCIÓN}

1.1. Tendencias en nutrición 1

1.2. Alimentos a base de maíz 1

1.3. Incorporación de semillas y harina de lino en alimentos 3

1.4. Aprovechamiento de subproductos de elaboración de pastas de maíz 5

1.5. Ingredientes naturales para la obtención de un postre saludable 6

1.5.1. Concentrado proteico de suero lácteo $(\mathrm{CPL}) \quad 6$

1.5.2. Extractos vegetales con poder antioxidante: Yerba mate 9

1.5.3. Miel 12

1.6. Alimentos especiales para fines específicos: Celiaquía 13

1.7. Objetivos generales $\quad 15$

1.8. Objetivos específicos 15

\section{CAPÍTULO 2}

\section{MATERIALES Y MÉTODOS}

2.1. Materiales 16

2.2. Formulación y elaboración de los snacks $\quad 16$

2.2.1. Obtención de la pasta de maíz 16

2.2.2. Elaboración de los snacks control 17

$\begin{array}{ll}\text { 2.2.3. Elaboración de los snacks con agregado de harina de lino } & 18\end{array}$

2.2.4. Elaboración de los snacks con harina de lino y yerba mate 19

2.2.4.1. Preparación de los extractos de yerba mate 19

2.2.4.2. Preparación de los snacks 19

2.3. Formulación y elaboración del postre 21

2.3.1. Ensayos de gelificación del concentrado proteico de lactosuero (CPL) 21

2.3.2. Preparación del postre 21

2.4. Caracterización fisicoquímica de los productos elaborados 22

2.4.1. Color superficial 22

2.4.2. Humedad 23

2.4.3. Determinación de actividad acuosa 23

2.4.4. Capacidad de retención de agua de los geles 25

2.4.5. Estudio de la textura de los snacks 25

2.4.6. Determinación de las características texturales de los geles 26

2.4.7. Análisis reológico de los geles 28 
2.4.8. Microscopía electrónica de barrido (SEM) 29

2.4.9. Microscopía confocal laser de barrido 30

2.4.10. Análisis de composición química 30

2.4.10.1. Proteínas totales 31

2.4.10.2. Lípidos 31

2.4.10.3. Cenizas 32

2.4.11. Determinación de $\mathrm{pH}$

2.4.12. Determinación del contenido de polifenoles y flavonoides totales y actividad antioxidante (DPPH y ABTS)

2.4.12.1. Método de extracción de polifenoles y flavonoides de las matrices de snacks y geles 33

2.4.12.2. Polifenoles totales 33

2.4.12.3. Flavonoides totales $\quad 34$

2.4.12.4. Actividad antioxidante por método DPPH 34

2.4.12.5. Actividad antioxidante por método ABTS 35

2.4.13. Análisis sensorial de los snacks elaborados 35

2.5. Análisis estadístico 36

\section{CAPÍTULO 3}

\section{FORMULACIÓN Y CARACTERIZACIÓN DE LOS SNACKS}

3.1. Formulación del snack base y determinación de las condiciones óptimas de $\begin{array}{ll}\text { procesamiento } & 37\end{array}$

3.2. Efecto del agregado de harina de lino sobre las características fisicoquímicas y de textura de los snacks

3.2.1. Apariencia visual y color de los snacks 40

3.2.2. Humedad y actividad acuosa 42

3.2.3. Propiedades de textura de los snacks 43

3.3. Efecto del agregado de extracto de yerba mate sobre las propiedades fisicoquímicas y de textura de los snacks con harina de lino 46

3.3.1. Apariencia visual y color de los snacks con yerba mate 46

3.3.2. Humedad y actividad acuosa 47

$\begin{array}{ll}\text { 3.3.3. Propiedades de textura } & 48\end{array}$

3.4. Almacenamiento de los snacks con harina de lino y extracto de yerba mate $\quad 49$

3.4.1. Variación de la actividad acuosa 49

3.4.2. Modificaciones en la textura de los snacks con harina de lino 50

3.4.3. Comportamiento de textura de snacks con harina de lino y yerba mate 52

3.5. Análisis de la microestructura de los snacks 54 
3.5.1. Microscopía electrónica de barrido $\quad 54$

3.5.2. Microscopía confocal laser de barrido 56

3.6. Composición química de los snacks con harina de lino y yerba mate 57

3.6.1. Análisis composicional 57

3.6.2. Contenido de polifenoles y flavonoides totales y actividad antioxidante (DPPH y ABTS) 58

3.6.3. Contenido de prolaminas $\quad 59$

3.7. Análisis sensorial de los snacks elaborados 60

3.8. CONCLUSIONES PARCIALES 62

\section{CAPÍTULO 4}

\section{APROVECHAMIENTO DEL CLARO DE MAÍZ PARA LA GENERACIÓN DE UN POSTRE}

4.1. Evaluación del agregado de concentrado de proteínas de suero lácteo al claro de maíz

4.2. Análisis reológico de los geles obtenidos $\quad 65$

4.2.1. Efecto del agregado de harina de lino y de las condiciones del proceso 65

$\begin{array}{ll}\text { 4.2.2. Efecto del agregado de miel } & 67\end{array}$

4.3. Determinación de las características texturales de los geles 69

4.3.1. Efecto de la harina de lino sin y con precalentamiento 69

4.3.2. Efecto del agregado de miel a los geles con harina de lino y CPL $\quad 70$

4.4. Color de los geles $\quad 71$

4.5. Capacidad de retención de agua de los geles $\quad 72$

4.6. Composición química del postre desarrollado 73

$\begin{array}{ll}\text { 4.6.1. Análisis composicional } & 73\end{array}$

4.6.2. Determinación del contenido de polifenoles totales de los geles $\quad 74$

4.7. Análisis sensorial del postre desarrollado

4.8. CONCLUSIONES PARCIALES 76

$\begin{array}{ll}\text { CONCLUSIONES GENERALES } & 77\end{array}$

$\begin{array}{lr}\text { BIBLIOGRAFÍA } & 79\end{array}$ 


\section{Indice de Figuras}

Figura 1.1 Estructura del grano de maíz 2

Figura 1.2 Semillas de lino y mucílago obtenido de la semilla 4

$\begin{array}{ll}\text { Figura 1.3 Concentrado de proteínas de lactosuero en polvo } & 7\end{array}$

Figura 1.4 Mecanismo de acción antioxidante de compuestos fenólicos 9

Figura 1.5 Diagrama de flujo del proceso de elaboración de yerba mate 11

Figura 1.6 Mecanismos patogénicos de la enfermedad celíaca. 13

Figura 2.1 Diagrama de flujo del proceso base para obtener la pasta maíz $\quad 17$

Figura 2.2 Diagrama de flujo del proceso para elaborar los snacks control 18

Figura 2.3 Diagrama de flujo del proceso para elaborar los snacks

con agregado de harina de lino $\quad 18$

Figura 2.4 Diagrama de flujo del proceso para elaborar los snacks con agregado de extracto de yerba mate 20

Figura 2.5. Diagrama de flujo del proceso para elaborar los geles 22

Figura 2.6 Esquema del espacio de color CIELab 23

Figura 2.7 Medidor de actividad acuosa 24

Figura 2.8 Medida de textura del snack 25

Figura 2.9 Curva típica de esfuerzo vs. deformación $\quad 27$

Figura 2.10 Sonda para ensayo de penetración en texturómetro 27

Figura 2.11 Reómetro oscilatorio $\quad 29$

Figura 2.12 Presentación de las muestras a los panelistas 36

$\begin{array}{ll}\text { Figura 3.1 Rendimiento de la pasta obtenida } & 37\end{array}$

Figura 3.2 Fotografías de pasta de maíz y líquido de cocción 38

Figura 3.3 Perfiles de textura de pastas de maíz $\quad 39$

Figura 3.4 Apariencia de los snacks obtenidos a partir de maíz y harina de lino $\quad 40$

Figura 3.5 Parámetros de color de los snacks con harina de lino 42

Figura 3.6 Efecto del agregado de harina de lino sobre contenido de humedad y actividad acuosa de snacks a base de maíz $\quad 43$

Figura 3.7 Perfiles de textura de los snacks con harina de lino 44

Figura 3.8 Apariencia de los snacks obtenidos a partir de maíz, harina de lino y extracto de yerba mate $\quad 46$

$\begin{array}{ll}\text { Figura 3.9 Parámetros de color de snacks } & 46\end{array}$

Figura 3.10 Perfiles de textura de los snacks 48

Figura 3.11 Estrés de fractura, módulo elástico y tensión de fractura de los snacks sin y con harina de lino 
Figura 3.12 Estrés de fractura, módulo elástico y tensión de fractura de los snacks con harina de lino y extracto de yerba mate

Figura 3.13 Microscopía electrónica de barrido de los snacks 55

Figura 3.14 Microscopía confocal laser de barrido de los snacks 56

Figura 3.15 Evaluación sensorial de los snacks 61

Figura 4.1 Espectro mecánico de los geles 66

Figura 4.2 Espectro mecánico de los geles con miel 68

Figura 4.3 Efecto de la harina de lino sobre los parámetros de color de los geles 71

Figura 4.4 Efecto de la harina de lino con precalentamiento y de la miel sobre el color de los geles $\quad 72$

Figura 4.5 Puntajes de los atributos sensoriales del postre elaborado 75 


\section{Indice de Tablas}

Tabla 1.1 Composición química del grano de maíz 2

Tabla 1.2 Composición aproximada de la semilla de lino 5

Tabla 1.3 Composición de los sueros de leche dulce y ácido $\quad 7$

Tabla 1.4. Aplicación de proteínas lactosuero en alimentos 8

Tabla 1.5. Contenido nutricional del extracto acuoso de yerba mate 10

Tabla 1.6 Composición típica de la miel 12

Tabla 2.1 Codificación utilizada en las muestras de snack 21

Tabla 3.1 Parámetros de color superficial de materias primas y productos snack 41

Tabla 3.2 Estrés de fractura, módulo elástico y tensión de fractura de los snacks 44

Tabla 3.3 Efecto del extracto de yerba mate sobre el contenido de humedad y la $\begin{array}{ll}\text { actividad acuosa de los snacks } & 47\end{array}$

Tabla 3.4 Estrés de fractura, módulo elástico y tensión de fractura de los snacks 48

Tabla 3.5 Actividad acuosa en función del tiempo de almacenamiento y de la composición de los snacks $\quad 49$

Tabla 3.6 Composición centesimal de los snacks de maíz 57

Tabla 3.7 Contenido total de polifenoles y flavonoides y actividad antioxidante (DPPH y ABTS) 58

Tabla 3.8 Contenido de prolaminas de los snacks de maíz 60

Tabla 4.1 Efecto de la composición y de las condiciones de proceso sobre los parámetros de textura de geles de claro de maíz 69

Tabla 4.2 Efecto del agregado de miel a geles de claro de maíz con CPL y harina de lino sobre los parámetros de textura $\quad 70$

Tabla 4.3 Capacidad de retención de agua de geles a base de claro de maíz $\quad 73$

Tabla 4.4 Comparación de la Información nutricional del postre desarrollado y un postre comercial $\quad 74$

Tabla 4.5 Contenido de polifenoles totales en diferentes muestras $\quad 74$ 
Capítulo 1

Introducción 


\subsection{Tendencias en nutrición}

En los últimos años, la promoción del estilo de vida saludable condujo a los consumidores a elegir los alimentos que se asocian con su salud y bienestar. La variedad en texturas, sabores, como así también el mayor aporte nutricional, tamaño y tipo de envase, etc., son tenidos en cuenta al momento de la compra del alimento, como así también el ahorro de tiempo que brindan los productos pre-elaborados (Mintel Report, 2018).

Por otro lado, en las últimas décadas se produjo la revalorización de los cereales en los alimentos listos para consumir, como es el caso de snacks y cereales para desayuno, con el consiguiente desarrollo de procesos para su elaboración (Wójtowicz y col., 2015). Este tipo de alimentos pueden ser formulados a partir de ingredientes o aditivos con funciones específicas, según se desee enriquecer el producto en un nutriente esencial o se encuentre dirigido a cierto rango etario (Potter y col., 2013) o con algún tipo de patología (Reis y Abu-Ghannam, 2014, Mir y col., 2019). Además, existe una tendencia creciente a la utilización de residuos vegetales o de subproductos de diversas industrias para formular alimentos enriquecidos con antioxidantes, minerales, vitaminas y otros compuestos biológicamente activos que aporten un beneficio adicional a la salud (Sun-Waterhouse y col., 2010, Mäkilä y col., 2014, Yuksel y col., 2014, Cueto y col., 2017).

\subsection{Alimentos a base de maíz}

En la alimentación humana el maíz (Zea mays sp.) se destina en su mayor parte a la producción de almidón (molienda húmeda) y más del $70 \%$ de éste es convertido en jarabes de glucosa y de fructosa. La otra forma de utilización del maíz es a través de la molienda seca, siendo ésta muy variada y dependiente de varios factores, entre ellos los culturales. Por ejemplo, en México los productos denominados "tortillas" se elaboran con el grano entero molido (incluyendo el germen) (Fig. 1.1), previamente cocido en agua de cal. Este proceso llamado "nixtamalización" utiliza molinos de muelas o discos, transformando al grano hidratado en una masa Guzmán, (2009). La cocción en álcali provoca la degradación del pericarpio, la pérdida de proteínas solubles (albúmina y globulina de bajo peso molecular contenidas en el germen) y la gelatinización parcial del almidón. Debido a la estructura compacta del grano de maíz (Fig. 1.1), la extensión del tratamiento con álcali está dominada fuertemente por la difusión de iones calcio en la estructura compleja del grano. A temperaturas comunes de ebullición $\left(90-100^{\circ} \mathrm{C}\right)$, el grano de maíz sufre gelatinización parcial, facilitando el transporte y la unión de los iones calcio. 


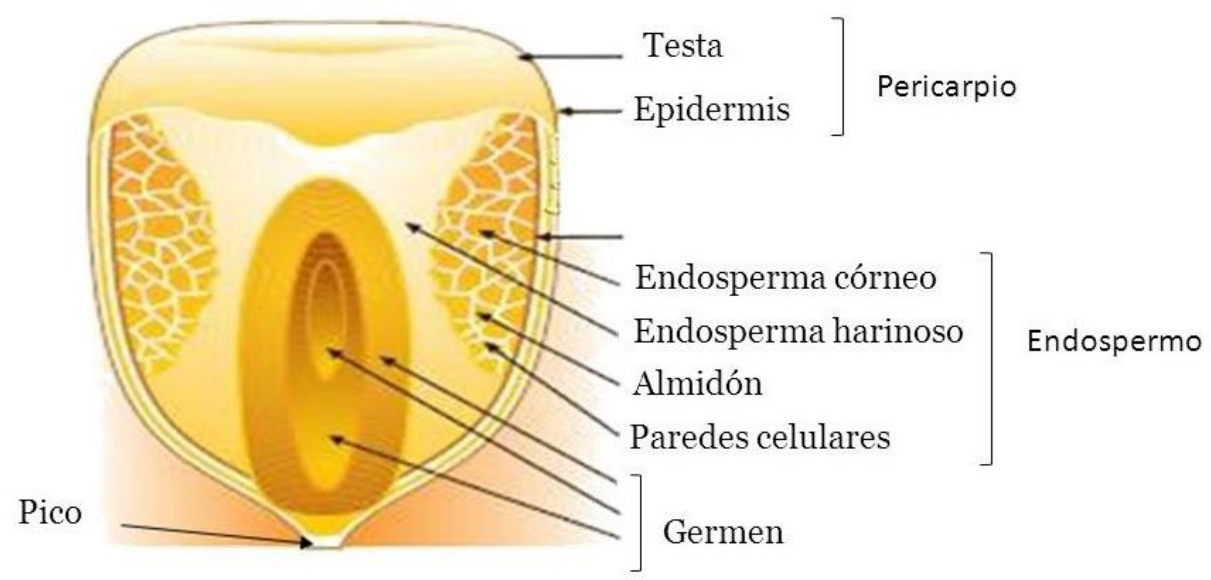

Figura 1.1. Estructura del grano de maíz. Fuente: delmaiz.info

En el caso de productos como la "polenta" y la "arepa" (producto panificado típico de Colombia), su elaboración parte del grano de maíz molido, previamente desgerminado y descascarado, donde se utiliza la fracción del endospermo rica en almidón y con alto contenido de proteínas (Tabla 1.1). En el presente trabajo se pretende obtener un snack tomando como base el proceso de elaboración tradicional de las arepas, donde se obtiene una pasta a partir del calentamiento de los granos de maíz pisado colorado con agua potable (Marín y col., 2011). Ya que el producto final planteado no es un panificado, las etapas de laminado, moldeado y horneado serán diferentes al de las arepas.

Tabla 1.1. Composición química del grano de maíz

\begin{tabular}{cccc}
\hline $\begin{array}{c}\text { Componente } \\
\text { químico }\end{array}$ & Pericarpio & Endospermo & Germen \\
\hline Proteínas & 3,7 & 8,0 & 18,4 \\
Extracto etéreo & 1,0 & 0,8 & 33,2 \\
Fibra cruda & 86,7 & 2,7 & 8,8 \\
Cenizas & 0,8 & 0,3 & 10,5 \\
Almidón & 7,3 & 87,6 & 8,3 \\
Azúcar & 0,3 & 0,6 & 10,8 \\
\hline
\end{tabular}

Fuente: Watson (1998). 
La cocción de los granos de maíz en agua involucra la gelatinización del almidón del endospermo, sin embargo, la estructura del grano de maíz hace que este proceso ocurra en forma diferente de lo que sucede en matrices con almidones o harinas puros o, como se mencionó anteriormente, en los granos sometidos a nixtamalización. El proceso de gelatinización involucra la pérdida de la estructura ordenada del almidón luego del calentamiento en presencia de suficiente agua, generalmente mayor a un $30 \%$ dependiendo de la fuente botánica del almidón. Durante este proceso los gránulos de almidón absorben agua, aumentando varias veces su tamaño y liberando al medio las cadenas de amilosa y amilopectina lo que provoca la pérdida de cristalinidad del gránulo y un aumento de la viscosidad del medio. Al avanzar el calentamiento, se produce ruptura de los gránulos y pérdida de la integridad (Ratnayake y Jackson, 2006).

En cambio, al utilizar granos de maíz, la cocción con agua en ebullición puede demandar un tiempo aproximado de 2,5 a 3 horas, como en la preparación de las arepas. Parte del almidón contenido originalmente en el grano de maíz no se libera, pero sí absorbe agua, lo que hace que el grano aumente su volumen formando la pasta de maíz hidratada. La cantidad de almidón liberada durante la cocción, con potencial aplicación, es de aproximadamente el $40 \%$ del almidón original del grano de maíz crudo. De esta forma, las cadenas de amilosa y amilopectina liberadas del interior del grano de maíz quedan en disolución en el líquido de cocción denominado "claro de maíz" (García y col., 2006).

Un factor importante para tener en cuenta son las características reológicas de la pasta obtenida ya que se observa pegajosidad, que hace que se adhiera fuertemente a la cinta de amasado, y no cohesividad, que conduce a una inadecuada formación del producto. Por lo tanto, es importante incorporar ingredientes que ayuden a la formación de una pasta cohesiva y laminable del snack y de ser posible que sean naturales y de bajo costo. Por ello, en este trabajo se utilizará harina de lino, subproducto de la industria aceitera, con alto contenido proteico y de fibra en forma de mucílago que contribuyen al mejoramiento de las características del sistema.

\subsection{Incorporación de semillas y harina de lino en alimentos}

Las semillas de lino (Linum usitatissimum L.) (Fig. 1.2a) son fuentes ricas en ácidos grasos $\Omega-3$ (ácido a-linolénico y sus derivados de cadena larga), como así también de fibra dietaria, proteínas y antioxidantes. Los ácidos grasos $\Omega$-3 junto a los $\Omega-6$, cuyo precursor es el ácido linoleico, forman parte de los denominados ácidos grasos esenciales. Estos ácidos grasos poli-insaturados son muy importantes para la 
nutrición humana pero el organismo no puede sintetizarlos y deben ser incorporados a partir de la dieta.
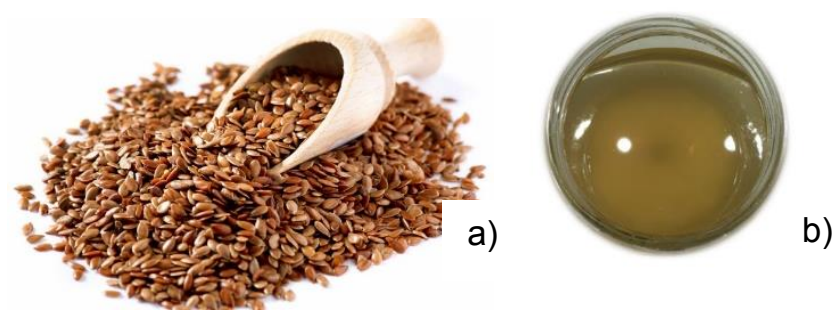

Figura 1.2. a) Semillas de lino, b) Mucílago obtenido por extracción de las semillas en medio acuoso.

Además de gran cantidad de ácidos grasos $\Omega-3$ (alrededor de $50 \%$ de $\alpha$ linolénico), las semillas de lino contienen lignanos, proteínas de alta calidad, fibra soluble y compuestos fenólicos (Oomah., 2001). La goma denominada mucílago constituye alrededor del $8 \%$ de la semilla (Fig. 1.2b), dando L-galactosa, D-xylosa, Larabinosa, L-rhamnosa y ácido D-galacturónico por hidrólisis ácida (Mazza y Biliaderis, 1989). El mucílago de lino posee buena capacidad de retención de agua y tanto sus propiedades reológicas como su capacidad de ligar agua son similares a las de la goma guar. Además, forma un gel débil en medio acuoso por lo que este mucílago puede utilizarse como reemplazo de otras gomas (Chen y col., 2006). Estos efectos, junto con su alto contenido de proteínas, hacen de las semillas de lino un ingrediente alimentario muy atractivo que lo posiciona como uno de los alimentos funcionales más destacados de los últimos años.

Si bien la semilla de lino entera proporciona una textura crocante a productos de repostería, cereales de desayuno, barras de cereales, etc., se recomienda su uso como semilla molida o harina, como se aplica en esta tesis. En la Tabla 1.2 se observa la composición aproximada de la semilla de lino representada a través de medidas de uso común para los consumidores. En la harina de lino la digestibilidad y biodisponibilidad de sus componentes son mayores, ya que las semillas enteras tienden a pasar por el tracto gastrointestinal sin ser digeridas debido a que la cubierta de la semilla es resistente a la acción de las enzimas digestivas.

Mentes y col. (2008) hallaron que el uso de $10 \%$ de semilla de lino molida produjo un incremento marcado en el volumen de miga y retardó el envejecimiento de panes formulados con harina de trigo. Por su parte, Lipilina y Ganji (2009) prepararon panes con $30 \%$ de harina de lino y observaron un incremento en 15 veces el contenido de ácido linolénico, un $100 \%$ en ácido linoleico y un $70 \%$ en fibra dietaria, comparado con panes control. También en snacks preparados por extrusión de una mezcla de maíz y harina de lino se observó un incremento en 7 veces en el contenido de fibra dietaria y 
casi $100 \%$ en el contenido de proteínas respecto al control sin harina, con un buen nivel de aceptabilidad sensorial (Trevisan y Gomes Arêas, 2012).

Tabla 1.2. Composición aproximada de la semilla de lino basada en medidas comunesa

\begin{tabular}{ccccccccc}
\hline $\begin{array}{c}\text { Tipo de } \\
\text { linaza }\end{array}$ & $\begin{array}{c}\text { Peso } \\
\mathbf{( g )}\end{array}$ & $\begin{array}{c}\text { Medida } \\
\text { común }\end{array}$ & $\begin{array}{c}\text { Energía } \\
\text { (Kcal.) }\end{array}$ & $\begin{array}{c}\text { Grasa } \\
\text { total } \mathbf{( g )}\end{array}$ & $\begin{array}{c}\mathbf{A A L}^{\mathbf{b}} \\
\mathbf{( g )}\end{array}$ & $\begin{array}{c}\text { Proteína } \\
\mathbf{( g )}\end{array}$ & $\begin{array}{c}\text { CHO } \\
\text { Total } \\
\mathbf{( g )}\end{array}$ & $\begin{array}{c}\text { Fibra } \\
\text { dietética } \\
\text { total }(\mathbf{g})\end{array}$ \\
\hline $\begin{array}{c}\text { Análisis } \\
\text { aproximado }\end{array}$ & 100 & - & 450 & 41,0 & 23,0 & 20,0 & 29,0 & 28,0 \\
$\begin{array}{c}\text { Semilla } \\
\text { entera }\end{array}$ & 180 & 1 taza & 810 & 74,0 & 41,0 & 36,0 & 52,0 & 50,0 \\
& 11 & 1 cda. & 50 & 4,5 & 2,5 & 2,2 & 3,0 & 3,0 \\
& 4 & 1 cdta. & 18 & 1,6 & 0,9 & 0,8 & 1,2 & 1,1 \\
$\begin{array}{c}\text { Semilla } \\
\text { molida }\end{array}$ & 130 & 1 taza & 585 & 53,0 & 30,0 & 26,0 & 38,0 & 36,0 \\
& 8 & 1 cda. & 36 & 3,3 & 1,8 & 1,6 & 2,3 & 2,2 \\
& 2,7 & 1 cdta. & 12 & 1,1 & 0,6 & 0,5 & 0,8 & 0,8 \\
\hline
\end{tabular}

aBasado en un análisis aproximado llevado a cabo por la Comisión de Granos de Canadá. El contenido de grasa se determinó utilizando el Método Oficial Am 2-93 de la American Oil Chemists Society AOCS (AOCS).

El contenido de humedad fue de $7.7 \%$.

${ }^{\mathrm{b}} \mathrm{AAL}=$ Acido alfa-linolénico, el ácido graso esencial Omega-3.

${ }^{\mathrm{C}} \mathrm{CHO}=$ Carbohidrato.

${ }^{d}$ El carbohidrato total incluye carbohidratos como azúcares y almidones $(1 \mathrm{~g})$ y fibra dietética total $(28 \mathrm{~g})$ por cada $100 \mathrm{~g}$ de semilla de lino.

Las mezclas con harina de semillas de lino como ingrediente funcional para la elaboración de estos productos permiten ofrecer al consumidor, más allá de un snack, un alimento con un mejor perfil nutricional que los encontrados comercialmente en este tipo de productos. Debido a las características sensoriales de sabor y color, el nivel de harina de lino que se puede incorporar en la elaboración de alimentos está determinado por los cambios organolépticos y tecnológicos que ocurran en el procesamiento y en el almacenamiento. Si bien en Argentina su uso aún no ha sido legislado en el Código Alimentario, organismos como el Flax Council of Canada han obtenido en 2009 su aprobación como GRAS (generalmente reconocido como seguro) (Kozłowski, 2012).

\subsection{Aprovechamiento de subproductos de elaboración de pastas de maíz}

Como ya se mencionó, tanto el proceso de nixtamalización para las tortillas de maíz como el de elaboración de las arepas, son métodos de hidrococción que generan la masa de maíz que luego es laminada y cocida en horno para obtener el producto 
final. Sin embargo, durante el procesamiento de estas pastas de maíz se obtiene un líquido residual denominado "claro de maíz" que puede ser aprovechado para generar nuevos productos. Rosentrater (2006) comenta el potencial que presentan estos desechos para su reutilización con valor agregado, por ejemplo, pueden entrar en una etapa de reprocesamiento dando lugar a productos nuevos para aplicaciones en alimentos y otras industrias. De esta forma, se mejoraría la eficiencia de los procesos de producción al reducir la cantidad de residuos como parte del plan de mejora continua del proceso.

En el caso de la elaboración del snack, el líquido de cocción que no es absorbido completamente por el grano y que contiene almidón, liberado y solubilizado en agua caliente, puede emplearse para la producción de alimentos funcionales aptos para el segmento de la población celíaca, como postres y bebidas. Además, los grandes volúmenes del claro de maíz generados en el proceso del snack tienen una implicancia ambiental que debe resolverse. Por lo tanto, es de interés el aprovechamiento de este desecho del proceso para generar nuevos productos, por ello en este trabajo de Tesis se propone el desarrollo de un postre saludable a partir del claro de maíz, agregando proteínas de suero lácteo y extractos antioxidantes de yerba mate. Para potenciar el sabor del postre, se propone el agregado de miel como endulzante natural.

\subsection{Ingredientes naturales para la obtención de un postre saludable}

\subsubsection{Concentrado proteico de suero lácteo (CPL)}

En la búsqueda de nuevos productos en los cuales se puedan aprovechar las propiedades funcionales de residuos de procesos, las proteínas de lactosuero constituyen una buena alternativa. El suero lácteo se genera como subproducto de la elaboración de quesos y debe tratarse previamente a ser desechado como efluente por los problemas de contaminación ambiental que puede provocar (Meza, 2009).

Según el tipo de coagulación de la caseína empleada en la fabricación quesera, se genera lactosuero dulce o lactosuero ácido. De la coagulación enzimática se obtiene el lactosuero dulce, con un pH próximo al de la leche fresca, que por la estabilidad en su composición es el más empleado en la industria, a diferencia del lactosuero ácido, que resulta de una coagulación ácida o láctica. El suero lácteo presenta importantes efectos benéficos sobre la salud debido a su composición rica en proteínas, azúcares como lactosa y minerales como calcio, fósforo y potasio (Tabla 1.3). Las proteínas séricas poseen todos los aminoácidos esenciales, son especialmente ricas en aminoácidos azufrados, que mejoran la función inmune a 
través de su conversión a glutatión, y en aminoácidos de cadena ramificada, isoleucina, leucina y valina, importantes en el área de suplementos para deportistas. Poseen actividad antimicrobiana y antioxidante y previenen la enfermedad cardiovascular, el cáncer y la osteoporosis (Keri Marshall, 2004).

Tabla 1.3. Composición de los sueros de leche dulce y ácido.

\begin{tabular}{ccc}
\hline Componente & \multicolumn{2}{c}{ Lactosuero (g/L) } \\
\cline { 2 - 3 } & Dulce & Ácido \\
\hline Sólidos totales & $63,0-70,0$ & $63,0-70,0$ \\
Lactosa & $46,0-52,0$ & $44,0-46,0$ \\
Grasa & $0-5$ & $0-5$ \\
Proteína & $6,0-10,0$ & $6,0-8,0$ \\
Calcio & $0,4-0,6$ & $1,2-1,6$ \\
Fósforo & $0,4-0,7$ & $0,5-0,8$ \\
Potasio & $1,4-1,6$ & $1,4-1,6$ \\
Cloruro & $2,0-2,2$ & $2,0-2,2$ \\
\hline
\end{tabular}

Fuente: Hernández y col. (2014).

A través de los procesos de concentración por ultrafiltración y secado por aspersión, el suero lácteo es convertido en un polvo con elevada concentración de proteínas. Desde el punto de vista económico, el lactosuero en polvo (Fig. 1.3) puede sustituir el agregado de leche en polvo aportando proteínas de alta calidad a casi la mitad del costo y reducir el agregado de endulzantes que son reemplazados por la lactosa.

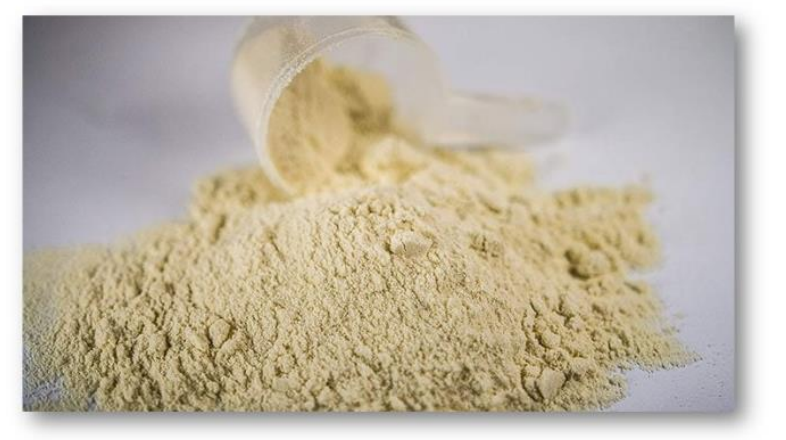

Figura 1.3. Concentrado de proteínas de lactosuero en polvo.

Entre las propiedades funcionales del lactosuero se destacan su alta solubilidad, poder emulsificante, capacidad de retención de agua, espumado, viscosidad, adhesividad y gelificación (Yamul, 2008). Una característica del concentrado de 
proteínas lácteas es la capacidad de formar geles por calentamiento de sus dispersiones acuosas. Durante el calentamiento se exponen residuos de aminoácidos hidrófobos ocultos dentro de la estructura de la proteína nativa resultando en un aumento de la reactividad de tales grupos. Entre ellos, los grupos sulfhidrilo de los residuos de cisteína pueden sufrir oxidación a disulfuros $(\mathrm{S}-\mathrm{S})$ o ácido cisteico $\left(-\mathrm{SO}_{3} \mathrm{H}\right)$ o reacciones de intercambio de disulfuro-sulfhidrilo (de Wit y Hontelez-Backx, 1984; Donovan y Mulvihill, 1987b; Kella y Kinsella, 1988). A través del intercambio sulfhidrilodisulfuro e interacciones hidrofóbicas, las moléculas de proteínas no plegadas pueden asociarse entre sí para formar agregados. Dependiendo de las condiciones ambientales, por ejemplo, $\mathrm{pH}$, concentración de sal y concentración de proteínas, esta agregación puede ser seguida por una precipitación, coagulación y/o gelificación (de Wit y Fox, 1989; Donovan y Mulvihill, 1987a, 1987b), modificando así las propiedades funcionales, estructurales y sensoriales del gel.

Debido al elevado contenido de proteínas de buena calidad presente en el suero lácteo, es cada vez mayor su utilización como ingrediente en la elaboración de alimentos (Rodríguez, 2016). Además, se puede utilizar estas proteínas de suero lácteo en la formulación de alimentos reducidos en calorías debido a su capacidad de imitar la textura que aporta la grasa (Chung y col., 2013).

Tabla 1.4. Aplicación de proteínas lactosuero en alimentos

\begin{tabular}{ll}
\hline Aplicación en lácteos & Helados, yogur, untables \\
Productos cárnicos & Carnes procesadas, embutidos \\
Panificados & Bases para tortas, galletitas, barras nutritivas \\
Productos de confitería & Chocolates, coberturas, caramelos \\
Bebidas & Mezclas con cacao, cremas para café, \\
& bebidas para deportistas \\
\hline Fuentes: Meza (2009), Sarabhai y Prabhasankar (2015), Rodríguez y col. (2017).
\end{tabular}

Respecto a la aplicación de los concentrados proteicos en postres, Hideko y col. (2004) emplearon concentraciones de 1-3\% en la elaboración de un postre lácteo cremoso de chocolate. Estos autores hallaron que es posible sustituir la leche en polvo por el concentrado de lactosuero, resultando un producto con menos grasa y sólidos totales y mayor contenido de proteínas. La evaluación sensorial mostró que el producto elaborado con $1 \%$ del concentrado proteico fue el preferido, con aceptación por encima del valor de 4 (bueno). 


\subsubsection{Extractos vegetales con poder antioxidante: Yerba mate}

En los nuevos alimentos formulados se busca incorporar componentes como los antioxidantes, sustancias que disminuyen significativamente los efectos adversos de las especies reactivas de oxígeno o nitrógeno en funciones fisiológicas normales (Cueto y col., 2015). Existen fuertes indicaciones a partir de estudios epidemiológicos y clínicos de que el consumo diario de frutas y vegetales ricos en polifenoles está relacionado con una menor incidencia de las enfermedades. Así, los polifenoles son considerados cada vez más como esenciales para la salud humana debido a que suprimen los efectos nocivos de los radicales libres sobre la fisiología normal (Cömert y Gökmen, 2018). En la Fig. 1.4 se muestran las reacciones químicas que intervienen en el mecanismo de acción de los compuestos fenólicos.

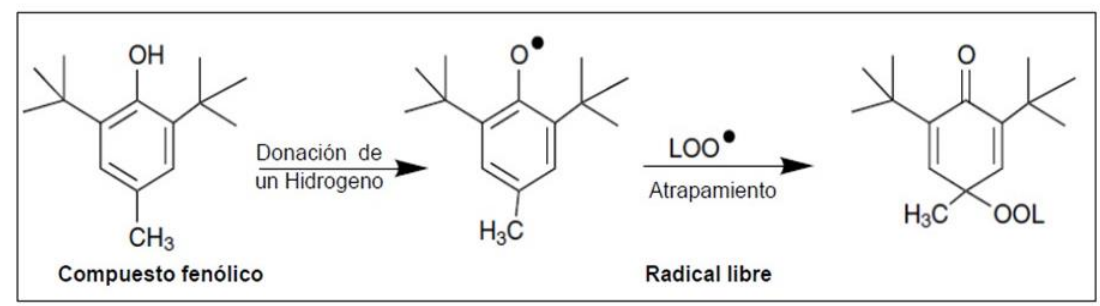

Figura 1.4. Mecanismo de acción antioxidante de compuestos fenólicos.

Fuente: Pokorny y col. (2001).

La planta de yerba mate (Ilex paraguariensis) es considerada una fuente rica de antioxidantes y de una gran variedad de compuestos que aportan beneficios para la salud. Es una planta nativa de la región subtropical de América del Sur, consumida y producida principalmente en Argentina, el sur de Brasil, Uruguay y Paraguay. En estos países se ingiere como bebida en proporciones de más de un litro por día por millones de personas, como mate, mate cocido o tereré. La yerba mate contiene compuestos químicos como derivados cafeicos, aminoácidos, flavonoides, minerales $(\mathrm{K}, \mathrm{Ca}, \mathrm{Mg}, \mathrm{P}$, $\mathrm{Na}$ y $\mathrm{Fe}$ ) y vitaminas (C, B1 y B2). La mayoría de estos compuestos son de carácter hidrofílico lo que facilita su extracción en medio acuoso (Tabla 1.5). Los niveles de polifenoles en los extractos de yerba mate son mayores a los del té verde y comparables a los de los vinos rojos. Además, son particularmente ricos en ácidos clorogénicos, principales compuestos fenólicos presentes también en alimentos como café, frutilla, ananá, manzana, girasol y arándano (Bracesco y col., 2011). 
Tabla 1.5. Contenido nutricional de la yerba mate.

\begin{tabular}{lllrlr}
\hline & $\begin{array}{c}\text { Vitaminas } \\
(\mathbf{m g})\end{array}$ & \multicolumn{2}{c}{$\begin{array}{c}\text { Minerales } \\
(\mathbf{m g})\end{array}$} & \multicolumn{2}{c}{$\begin{array}{c}\text { Otros componentes } \\
(\mathbf{g})\end{array}$} \\
\hline C & 5,11 & Calcio & 80,94 & Glucosa & 0,59 \\
B1 & 1,48 & Fósforo & 45,89 & Sacarosa & 2,77 \\
Niacinamida & 1,27 & Hierro & 2,22 & Proteínas & 2,14 \\
Piridoxina & 0,94 & Magnesio & 58,58 & Cafeína & 0,85 \\
& & Potasio & 100,59 & Cenizas & 3,23 \\
& & Sodio & 14,04 & & \\
& & & & &
\end{tabular}

*Valores medios de 5 muestras comerciales diferentes. Los valores están referidos a 100 gramos de sólido seco (yerba mate). Fuente: Ramallo y col. (1998).

La elaboración de la yerba mate involucra diferentes etapas de procesamiento luego de la cosecha (Fig. 1.5). La primera de ellas, el sapecado, consiste en exponer las hojas a la acción directa del fuego vivo, durante 20 a 30 segundos. El paso siguiente es el secado de la yerba mate en cintas utilizando una corriente de aire indirecto, dentro de las 24 horas posteriores al sapecado. El objetivo es inactivar enzimas oxidativas y reducir la humedad de las hojas previniendo de este modo la oxidación y el deterioro del color, el sabor y el aroma de las hojas.

Una vez que la yerba está seca se la somete al canchado, proceso de trituración gruesa que permite facilitar su embolsado y transporte. Luego, la yerba canchada es depositada en cámaras de estacionamiento acelerado durante 30 ó 60 días o bien en descanso natural durante 9-12 meses. En el estacionamiento adquiere cuerpo, "bouquet" y se convierte en el alma del mate. Una vez canchada y estacionada, en el molino la yerba mate es triturada, zarandeada y mezclada según el uso y preferencias de cada región. Por último, la combinación o "blend" obtenido es estampillado y envasado. 


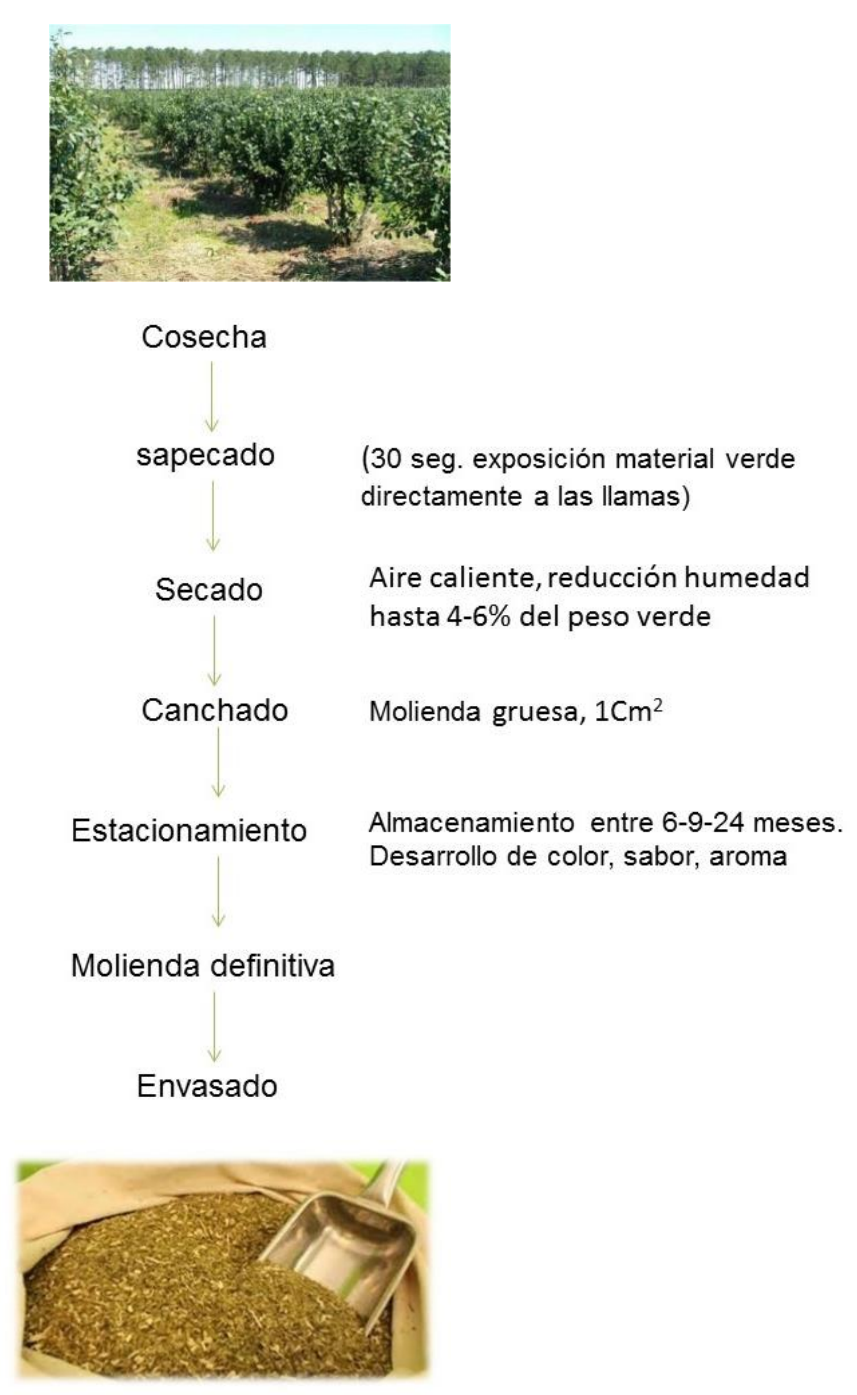

Figura 1.5. Diagrama de flujo del proceso de elaboración de yerba mate. Fuente: INYM

Durante el proceso de elaboración de yerba mate (Fig. 1.5) se generan, como subproducto, cantidades importantes de polvo, el cual en parte es agregado a la yerba comercial pero el excedente representa un problema para la industria yerbatera. Este polvo posee las mismas propiedades nutricionales de la yerba mate (Viera y col., 2010) lo cual lo convierte en un material ideal para la extracción de compuestos activos y su posterior aplicación como ingrediente funcional (Deladino y col., 2013, López Córdoba y col., 2015). Otros autores (Viera y col., 2008) han utilizado el polvo de yerba mate en la formulación de caramelos, incrementando así su contenido en polifenoles y minerales. La creciente demanda de los consumidores por productos con sabores nuevos o exóticos (Mintel Report, 2018) permite la aplicación de los extractos de yerba en la formulación de alimentos como snacks o postres, como los que se plantean desarrollar en este trabajo. 


\subsubsection{Miel}

Este producto es conocido mundialmente por su sabor dulce, delicado aroma y color atractivo. La industria de la miel presenta un potencial muy grande de explotación debido a las condiciones agroclimáticas favorables que Argentina posee en la mayor parte de su territorio. Nuestro país es el cuarto productor y segundo exportador de miel en el mundo (Sánchez y col., 2018). La mayor parte de esta miel es exportada a granel sin ningún tipo de valor agregado.

La miel posee propiedades nutricionales interesantes como la de aportar compuestos con actividad antioxidante, como resultado de la presencia de compuestos fenólicos, péptidos, ácidos orgánicos, enzimas y productos de la reacción de Maillard (Socha y col., 2011). La miel tiene un pH entre 3,4 y 6,1 y desde el punto de vista químico está compuesta por azúcares (80-85\%), agua (15-20\%) y otros constituyentes minoritarios como minerales, proteínas, compuestos fenólicos, ácidos orgánicos y aminoácidos libres. La composición de la miel está influenciada principalmente por la flora dominante alrededor de los apiarios (Silvano y col., 2014) y la región geográfica (Patrignani y col., 2015), clima y tipo de suelo (Oroian y col., 2013). En la Tabla 1.6 se presentan valores de composición típica de la miel.

Tabla 1.6. Composición típica de la miel

\begin{tabular}{lc}
\hline \multicolumn{1}{c}{ Componente } & \% base húmeda * \\
\hline Glucosa & $22-41$ \\
Fructosa & $27-44$ \\
Sacarosa & $0,25-8$ \\
Maltosa & $3-16$ \\
Otros azúcares & $0,13-8,5$ \\
Humedad & $13-23$ \\
Ácidos totales & $0,2-1,2$ \\
Cenizas & $0,02-1,0$ \\
\hline${ }^{*}($ Kg/Kg de muestra $) \times 100$. Fuente: Bhandari y col. (1999).
\end{tabular}

El agregado de miel a sistemas gelificados, como el que se pretende en este trabajo, permite obtener productos con características nutricionales y sensoriales diferentes sugiriendo, de este modo, nuevas aplicaciones para este producto con el consecuente aumento de su valor agregado. 


\subsection{Alimentos especiales para fines específicos: Celiaquía}

Existe una parte de la población que presenta una patología relacionada a la ingesta de gluten y requiere alimentos especiales libres de éste en su dieta. Esta patología, denominada enfermedad celíaca, enteropatía sensible al gluten o esprúe no tropical, es un desorden autoinmune que tiene componentes genéticos, ambientales e inmunológicos y que afecta el intestino delgado de las personas con predisposición a esta enfermedad (Fig. 1.6). La ingesta de gluten presente en el trigo y de proteínas relacionadas en otros cereales como cebada y centeno, produce una atrofia de las vellosidades del intestino delgado que disminuye la absorción de los nutrientes de los alimentos (Alaedini y Green, 2005).

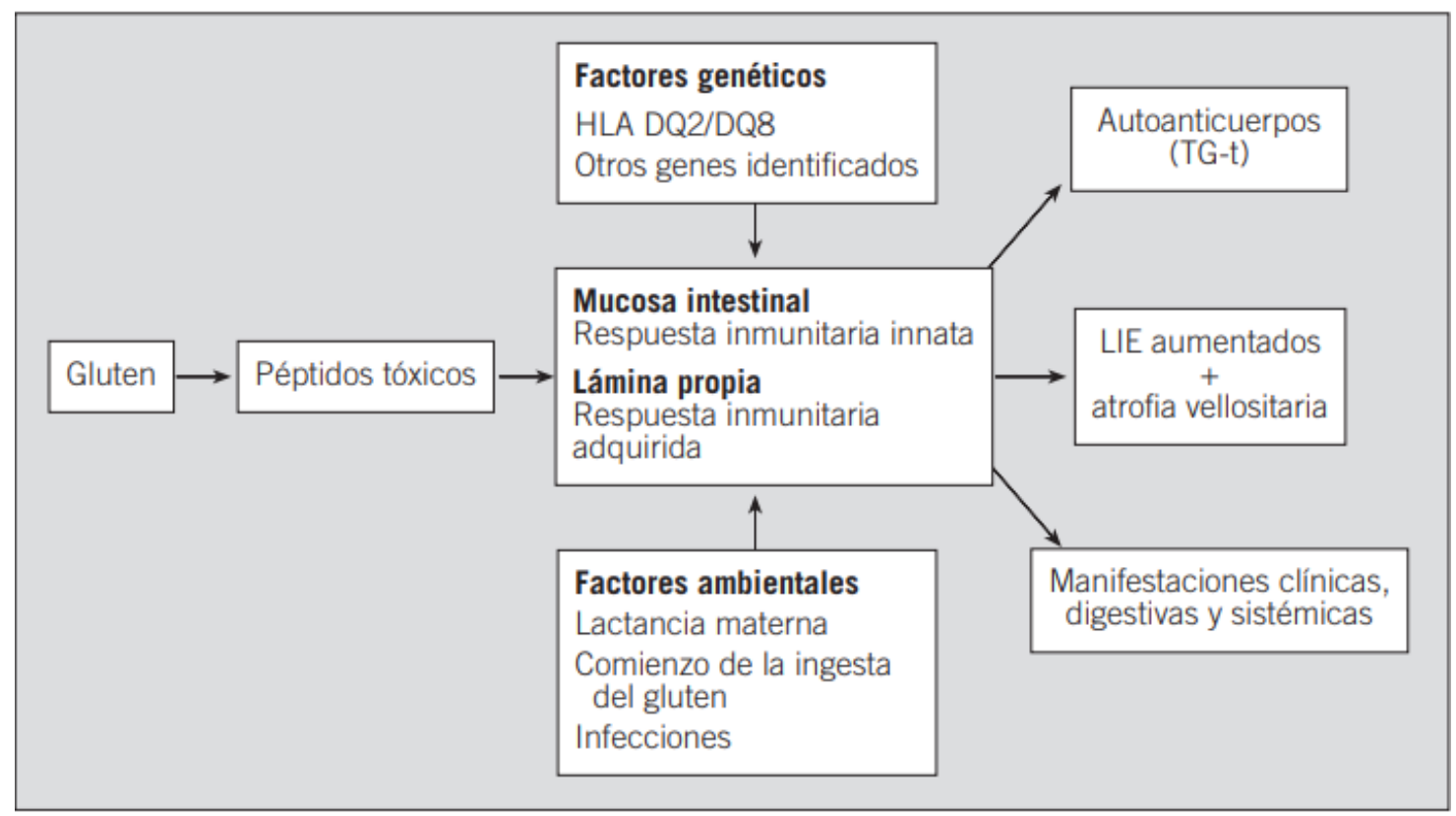

Figura 1.6. Mecanismos patogénicos de la enfermedad celíaca. HLA: sistema de antígenos de histocompatibilidad; LIE: linfocitos intraepiteliales; TG-t: anticuerpos contra la transglutaminasa tisular. Fuente: Rodrigo y col. (2008).

Actualmente, la enfermedad celíaca afecta en promedio al $1 \%$ de la población mundial y particularmente a individuos de origen europeo. También se presenta en forma común en África del Norte, Oriente Medio e India (Lionetti y col., 2015). En Argentina, Gómez y col. (2001) hallaron una prevalencia de 1 en 167 sobre 2000 adultos relevados. La presentación clínica de la enfermedad celíaca varía en un gran rango que va desde un cuadro asintomático hasta una malnutrición severa provocada por diarrea crónica, pérdida de peso y distensión abdominal (Alaedini y Green, 2005). En la infancia, la enfermedad se caracteriza por manifestaciones intestinales que comienzan entre los 6 y los 24 meses de edad, después de la introducción de gluten en la dieta. Las consecuencias de la enfermedad pueden observarse en el retraso en el desarrollo, baja estatura, diarrea crónica, esteatorrea, distensión abdominal y 
anemia (Fasano, 2005). En pacientes adultos, en cambio, pueden o no aparecer síntomas gastrointestinales, manifestándose la enfermedad a través de diversas patologías como dermatitis herpetiforme, anemia, osteoporosis, infertilidad y problemas neurológicos, entre otros (Alaedini y Green, 2005).

A través de la dieta es posible controlar la enfermedad celíaca eliminando en forma completa el gluten y las proteínas relacionadas de los productos alimenticios que contienen trigo, avena, cebada y centeno (rotulados como "sin T.A.C.C", por las siglas de estos cereales). Por ello, el maíz es el cereal más utilizado en la elaboración de alimentos para personas celíacas debido a que no contiene proteínas del gluten. Sin embargo, el aporte de proteínas en el maíz es nutricionalmente menor que en otros cereales por lo que se han ensayado mezclas con otras fuentes vegetales (Wu y col., 2010, Cueto y col., 2015). Por lo tanto, el desarrollo de nuevos productos a base de maíz que a su vez contengan los nutrientes necesarios de la dieta y que sean aptos para celíacos es un desafío tecnológico, sumado a la tendencia de consumo de alimentos bajos en calorías. Además, la utilización de subproductos de industrias de alimentos como ingredientes de las formulaciones contribuiría a disminuir, al menos en parte, los desechos industriales. 


\subsection{Objetivos generales}

- Optimizar la producción de alimentos a base de maíz a través del desarrollo de un snack y un postre, utilizando miel y subproductos provenientes de las industrias aceitera, láctea y de la yerba mate, para generar productos saludables que incluyan al segmento de la población celíaca.

\subsection{Objetivos específicos}

- Seleccionar y caracterizar ingredientes con alto contenido de compuestos activos, como la miel (antioxidantes) y los subproductos de industrias alimentarias, como la harina de lino (fibras, proteínas y antioxidantes), el polvo de la yerba mate (antioxidantes y minerales) y el concentrado proteico de lactosuero (proteínas).

- Formular y elaborar un producto tipo snack a base de maíz, harina de lino y extracto de yerba mate, que sea saludable y apto para celíacos, optimizando condiciones de proceso y concentración de ingredientes.

- Diseñar y formular un alimento tipo postre a partir del líquido de cocción del maíz (claro de maíz), a fin de utilizar este subproducto del procesamiento del snack. Incorporar proteínas de lactosuero y miel para enriquecer el valor nutricional de la formulación.

- Evaluar el efecto de los ingredientes y las variables de proceso sobre las propiedades fisicoquímicas, reológicas y de textura del snack y del postre, como así también sobre su composición y contenido de polifenoles.

- Determinar los cambios fisicoquímicos y de textura producidos en los alimentos formulados durante el almacenamiento en condiciones controladas.

- Evaluar la aceptabilidad general del snack y del postre a través de un panel sensorial evaluadores no entrenado. 
Capítulo 2

Materíales y Métodos 


\subsection{Materiales}

\section{Maíz}

Maíz amarillo (Zea mays sp.), pisado y desgerminado proveniente de molienda seca, adquirido en una dietética local.

\section{Harina de lino}

Harina de lino, con certificación "sin TACC" libre de gluten, marca Sturla (Argentina) y harina de lino desgrasada, ambas adquiridas en dietética local.

\section{Concentrado de proteínas de suero lácteo}

Concentración mínima de proteínas $77 \%$ p/p, según especificación del proveedor. Donado gentilmente por Arla Foods Ingredients S.A. (Martínez, Buenos Aires, Argentina).

\section{Yerba mate}

Marca La Merced (Establecimiento Las Marías, Corrientes, Argentina), adquirida en un comercio local.

\section{Miel}

Miel proveniente de apiarios de la provincia de Buenos Aires, adquirida en un comercio local y conservada en envases de plástico herméticos a $20^{\circ} \mathrm{C}$. Sus características fisicoquímicas son las siguientes: $\mathrm{pH} 4,16 \pm 0,02$, acidez 29,60 $\pm 1,35 \mathrm{meq} / \mathrm{kg}$, HMF $25,53 \pm 2,53 \mathrm{mg} / \mathrm{Kg}$, humedad $16,06 \pm 0,54 \%$, cenizas $0,18 \pm 0,02 \%$, color ámbar extra

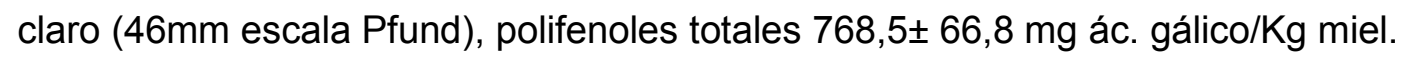

\subsection{Formulación y elaboración de los snacks}

\subsubsection{Obtención de la pasta de maíz}

El proceso base para la elaboración del snack y del postre (Fig. 2.1) comienza con la mezcla del maíz y del agua para obtener, por un lado, la pasta de maíz que será la materia prima para elaborar el snack y, por otro lado, el líquido de cocción que servirá como base para lograr el postre. 


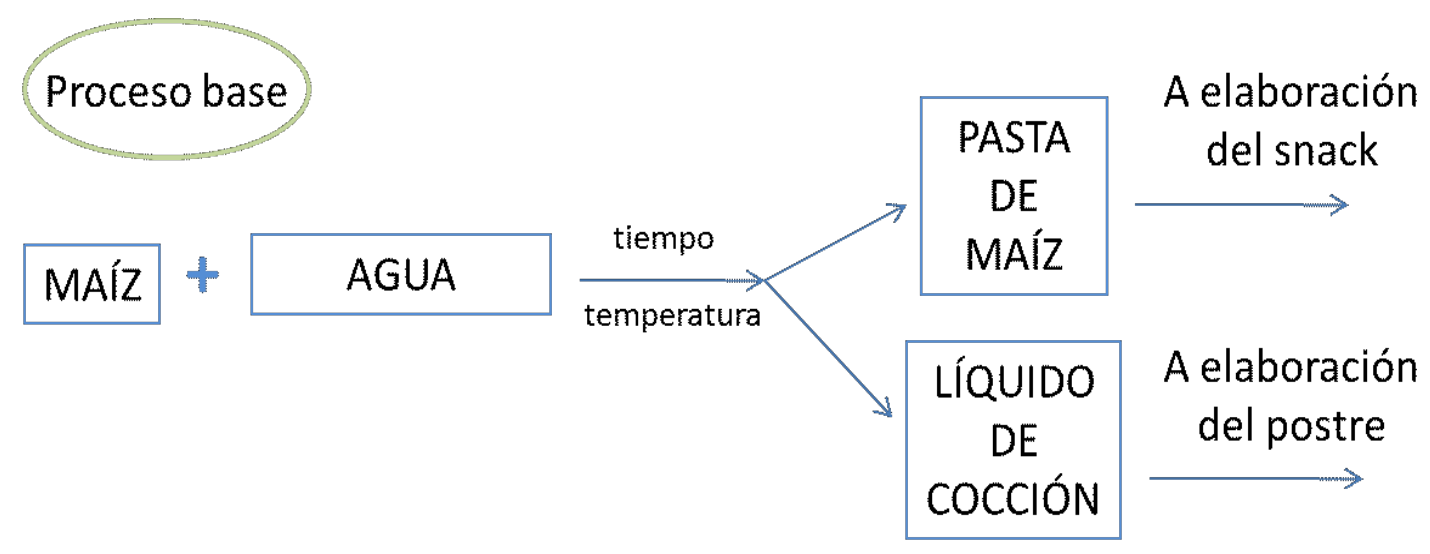

Figura 2.1. Diagrama de flujo del proceso base para obtener la pasta de maíz y el líquido de cocción.

Desde el punto de vista del proceso del snack es importante la obtención de una pasta de maíz uniforme, que no se resquebraje y sea fácil de laminar. Por ello, se debe determinar la relación maíz:agua y el tiempo y velocidad de calentamiento óptimos para lograr dicha pasta. Se ensayaron 2 tiempos de cocción, 60 y 80 min desde que inicia el ciclo, empleando diferentes relaciones maíz:agua (1:8 y 1:10).

Se pesaron en balanza granataria (Ohaus, CS2000, EE.UU.) lotes de $150 \mathrm{~g}$ de maíz a los que se les agregó la cantidad de agua respectiva. Las mezclas maíz-agua se colocaron en un recipiente metálico y se calentaron en hornalla a ebullición para permitir la cocción completa del maíz, ensayando velocidades de calentamiento bajas $\left(10-20^{\circ} \mathrm{C} / \mathrm{min}\right)$. La velocidad de calentamiento se midió utilizando un multímetro digital (Tobax Instruments, modelo DT-890-G, China) con termocupla colocada en el centro del recipiente utilizado para la cocción. Respecto a la temperatura del agua, se verificó que el sistema llegara a ebullición, tomando el tiempo de cocción desde el momento del inicio del ciclo de calentamiento. Luego de transcurridos los tiempos ensayados, se separó en un colador la fracción de maíz cocido y el agua de cocción y ambos productos se dejaron enfriar a temperatura ambiente hasta su utilización.

\subsubsection{Elaboración de los snacks control}

La Fig. 2.2 muestra el diagrama de flujo de obtención de los snacks control. La fracción del maíz cocido se procesó en picadora (Moulinex, Argentina) en ciclos de 10 segundos en 10 repeticiones. La pasta obtenida se amasó manualmente durante 2 min y luego se pasó por una laminadora de pastas hogareña (Pastalinda, Argentina) hasta lograr un espesor de $1 \mathrm{~mm}$. Posteriormente, se procedió al moldeado utilizando un cortapasta para 25 snacks por batch con una geometría circular tipo papa frita de 3,5 $\mathrm{cm}$ diámetro. Luego se procedió al horneado en un horno con convección forzada (Hitachi, Argentina) a $160^{\circ} \mathrm{C}$ durante 25 min obteniendo así el snack base. Una vez 
horneadas, las muestras se conservaron en bolsas de aluminio selladas y se almacenaron a temperatura ambiente.

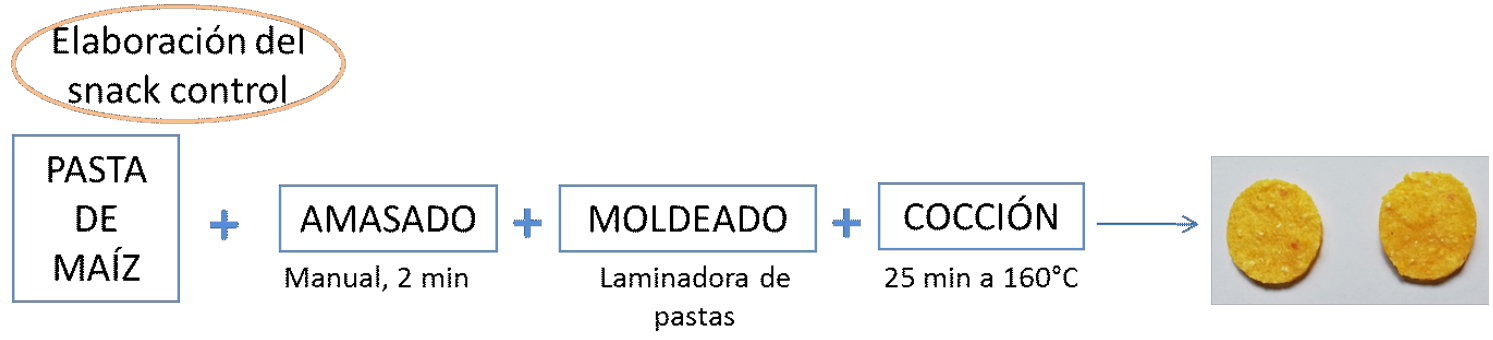

Figura 2.2. Diagrama de flujo del proceso para elaborar los snacks control.

\subsubsection{Elaboración de los snacks con agregado de harina de lino}

Una vez obtenidas las condiciones óptimas de procesamiento de la mezcla maíz:agua, se continuó con las formulaciones con agregado de harina de lino (Fig. 2.3).

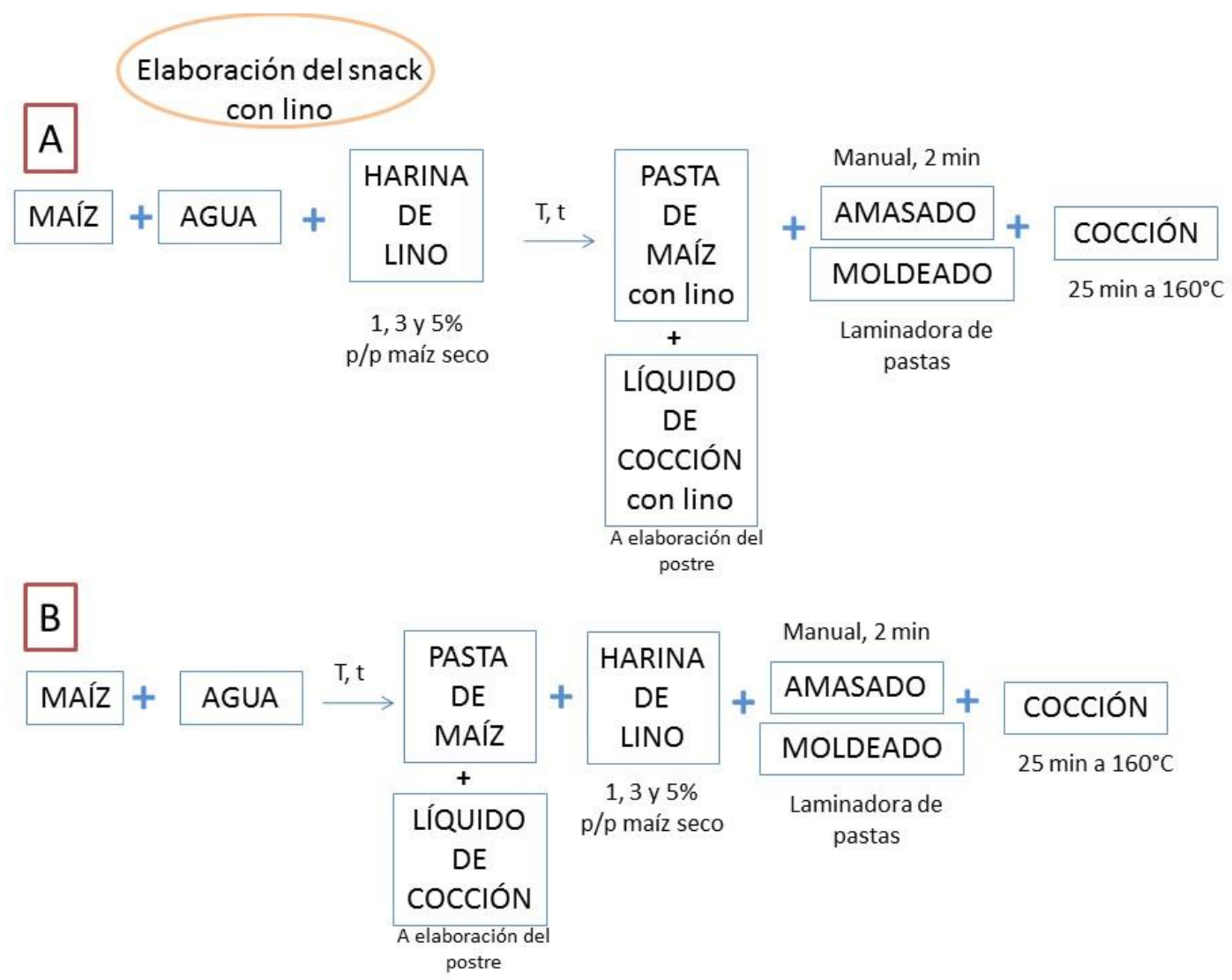

Figura 2.3. Diagrama de flujo del proceso para elaborar los snacks con agregado de harina de lino, A) en el agua previo al calentamiento, B) en la pasta de maíz cocida. 
La incorporación de lino al sistema base seleccionado se realizó como harina, por su mejor asimilación, en 3 niveles de concentración $1 \%\left(L_{1}\right), 3 \%\left(L_{3}\right)$ y $5 \%\left(L_{5}\right)$, en base al peso del maíz seco. Se partió de referencias de trabajos realizados en panificados en los cuales se lograron productos con buena aceptabilidad de color, textura y sabor (Ramcharitar y col., 2005; Hall y col., 2006; Figuerola, y col., 2008; Marpalle y col., 2014; Yuksel y col., 2014; Plencovich y col., 2017).

Además, se ensayó el agregado de la harina de lino en diferentes etapas del proceso (antes y después del calentamiento del maíz) (Fig. 2.3), a fin de evaluar los cambios en las propiedades de los snacks que ocurren según el procesamiento empleado. En el caso del agregado de la harina a la fracción de maíz cocida (proceso B, Fig. 2.3), se incorporó la misma en forma de lluvia durante el procesamiento en la picadora.

En ambos procesos, una vez obtenida la pasta, se procedió al amasado, moldeado y horneado según lo descripto en la sección anterior. Las muestras horneadas se dejaron enfriar y se conservaron en bolsas de aluminio selladas a temperatura ambiente.

\subsubsection{Elaboración de los snacks con agregado de harina de lino y extracto de yerba mate}

\subsubsection{Preparación de los extractos de yerba mate}

A fin de incluir los antioxidantes contenidos en la yerba mate se preparó un extracto al $6 \% \mathrm{p} / \mathrm{v}$ a partir del cual se prepararon soluciones de diferente concentración para ser utilizadas en la formulación del snack y del postre.

Se tamizaron 36 gramos de yerba mate en malla de $1 \mathrm{~mm}$ para eliminar los palos y así maximizar la cantidad de antioxidantes. Luego, al polvo de yerba obtenido se agregó $600 \mathrm{~mL}$ de agua destilada y se calentó a $90^{\circ} \mathrm{C}$ durante 20 min en un baño termostático (Haake, Alemania). De esta forma se obtuvo un extracto de yerba mate, el cual se filtró primero con colador y luego con papel de filtro Whatman $\mathrm{N}^{\circ} 1$ para obtener un líquido sin turbidez.

\subsubsection{Preparación de los snacks con harina de lino y extractos de yerba mate}

Para determinar la concentración óptima del extracto de yerba mate a los snacks se llevaron a cabo ensayos al $1 \%$ y $3 \%$ en peso de extracto respecto al volumen total del agua determinado para la cocción del maíz. A partir de ensayos de aceptabilidad sensorial preliminares se determinó que concentraciones mayores a $3 \%$ resultaban en 
snacks con características de astringencia marcadas, no siendo aceptables para su consumo.

El snack se preparó en las mismas condiciones descriptas en el punto anterior, reemplazando parte del agua de cocción por un volumen determinado de extracto de yerba mate, según la concentración final de extracto a ensayar (1\% ó 3\%). En cada caso se empleó una concentración de $3 \%$ de harina de lino y se procedió al moldeado y horneado de los snacks como se describió anteriormente (sección 2.2.2). La Figura 2.4 muestra el diagrama de flujo del proceso descripto:

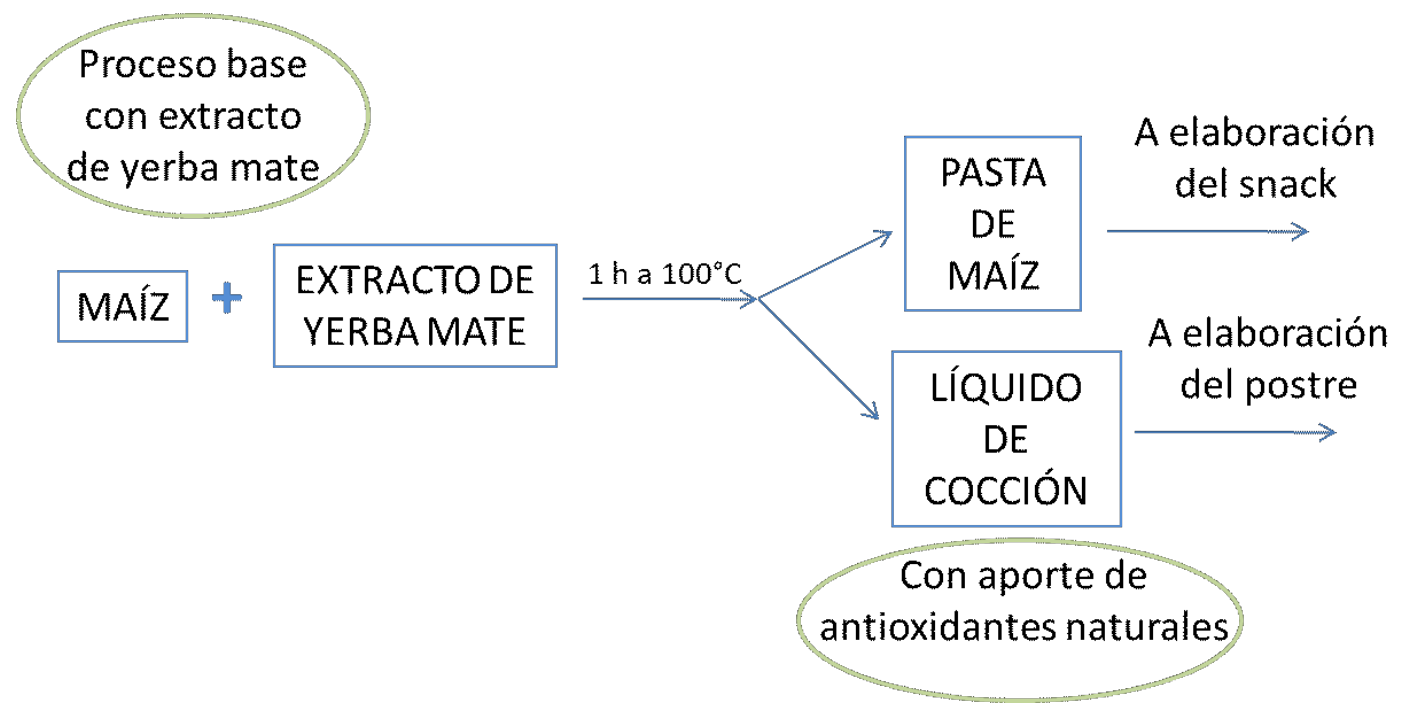

Figura 2.4. Diagrama de flujo del proceso para elaborar los snacks con agregado del extracto de yerba mate.

A modo de resumen, la Tabla 2.1 muestra las formulaciones de snacks y su respectiva codificación:

Tabla 2.1. Codificación utilizada en las muestras de snack, de acuerdo con las concentraciones de harina de lino y extracto de yerba mate incorporados.

\begin{tabular}{ccc}
\hline Muestra codificada & $\begin{array}{c}\text { Harina de lino } \\
(\%)\end{array}$ & $\begin{array}{c}\text { Extracto de yerba mate } \\
(\%)\end{array}$ \\
\hline $\mathrm{M}_{0}$ (control) & 0 & 0 \\
$\mathrm{~L}_{1}$ & 1 & 0 \\
$\mathrm{~L}_{3}$ & 3 & 0 \\
$\mathrm{~L}_{5}$ & 5 & 0 \\
$\mathrm{~L}_{3} \mathrm{Y}_{1}$ & 3 & 1 \\
$\mathrm{~L}_{3} \mathrm{Y}_{3}$ & 3 & 3 \\
\hline
\end{tabular}




\subsection{Formulación y elaboración del postre}

\subsubsection{Ensayos de gelificación del concentrado proteico de lactosuero (CPL)}

La concentración de proteínas es uno de los factores más importantes involucrados en la gelificación. Si la concentración de éstas es muy baja la gelificación no ocurrirá, pero una vez alcanzada la concentración mínima de proteínas requerida, la fuerza del gel aumenta y el tiempo de gelificación disminuye a medida que la concentración proteica aumenta (Taylor y col., 1994). Se ensayaron diferentes concentraciones de CPL $(5,7$ y $9 \%$ p/p) en el claro de maíz, a fin de encontrar la concentración mínima del concentrado proteico que permite lograr un gel de firmeza similar a los postres comerciales. Se seleccionaron estos niveles de CPL a partir de datos de bibliografía (Schmidt y col., 1978).

Se prepararon las dispersiones (CPL + agua de cocción del maíz), se homogeneizaron con agitación magnética y luego se transfirieron a recipientes de aluminio de forma cilíndrica, los cuales se calentaron a $90^{\circ} \mathrm{C}$ por $30 \mathrm{~min}$ en un baño de agua para permitir la gelificación.

\subsubsection{Preparación del postre}

Al sistema claro de maíz-CPL seleccionado en la etapa anterior, se le incorporó la harina de lino al $2 \%$ p/p (respecto al volumen del agua de cocción del maíz). Se evaluó el efecto del agregado de la harina de lino en diferentes etapas del proceso (Fig. 2.5):

a) Se agregó primero la harina de lino hasta disolución completa mediante agitación magnética, luego se agregó el CPL hasta que se disolvió completamente y se trasvasó a los moldes para ser llevados a baño de maría a $90^{\circ} \mathrm{C}$ por 30 min (Fig. 2.5a).

b) Se realizó de la misma manera que en el punto anterior, pero añadiendo la harina de lino con un precalentamiento y agitación por 15 minutos con temperatura $\left(45^{\circ} \mathrm{C}\right)$ (Fig. 2.5b).

Se ensayó para ambos tratamientos el agregado de miel a una concentración final del $8 \% \mathrm{p} / \mathrm{p}$ respecto al total de la formulación. 

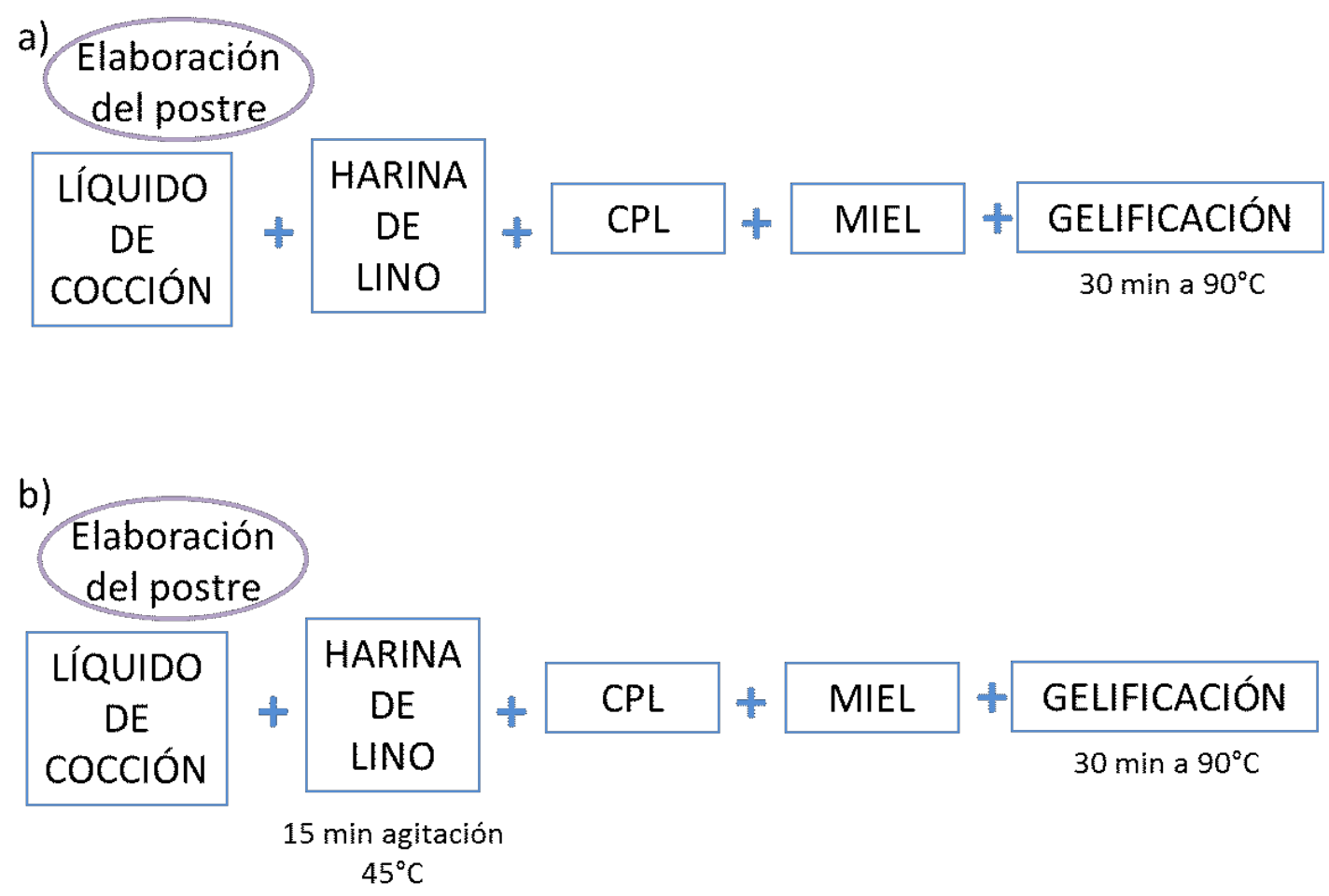

Figura 2.5. Diagramas de flujo del proceso para elaborar los geles con agregado de harina de lino $\sin$ (a) y con (b) precalentamiento, CPL y miel, a partir del líquido de cocción con antioxidantes de yerba mate.

Los geles obtenidos fueron tapados con film y almacenados en cámara a $0^{\circ} \mathrm{C}$ hasta los análisis respectivos. Se realizaron mediciones para los tiempos 0, 7, y 14 días previendo una vida útil del producto en este rango. En las pruebas de almacenamiento se observó que los geles no presentaron deterioro microbiológico a la vista hasta el día 25 .

\subsection{Caracterización físicoquímica de los productos elaborados}

\subsubsection{Color superficial}

La apariencia de un alimento juega un rol importante al momento de la aceptación por parte del consumidor, siendo el color un atributo sensorial relevante a través del cual se valora al alimento antes de su compra. La percepción del color depende de la iluminación, de la estructura y composición química del objeto y de los distintos tipos de receptores de la percepción humana (Sáenz y col., 1993).

Para la medición del color superficial de las muestras se utilizó un colorímetro de superficie Chromameter CR 300 Konica-Minolta (Konica-Minolta, Japón). Este equipo realiza la evaluación del color basándose en todo el espectro visible, permitiendo obtener el perfil cromático real del producto. El color se describe a través de los parámetros CIELab (Commission International de l'Eclairage, 1976): la luminosidad L* 
y la cromaticidad por los parámetros $a^{*}$ y $b^{*}$, como se describe en la Figura 2.6. El parámetro $L^{*}$ varía desde 100 para un blanco perfecto y 0 para el negro. El parámetro $a^{*}$ representa el color rojo cuando es positivo, y verde cuando es negativo y $b^{*}$ define el color amarillo cuando es positivo, y azul cuando es negativo. Las coordenadas $a^{*} y$ $b^{*}$ pueden ser transformadas en coordenadas polares para calcular el matiz $h^{*}$ (ángulo Hue) y la saturación o croma $C^{*}$. Las determinaciones se realizaron por triplicado.

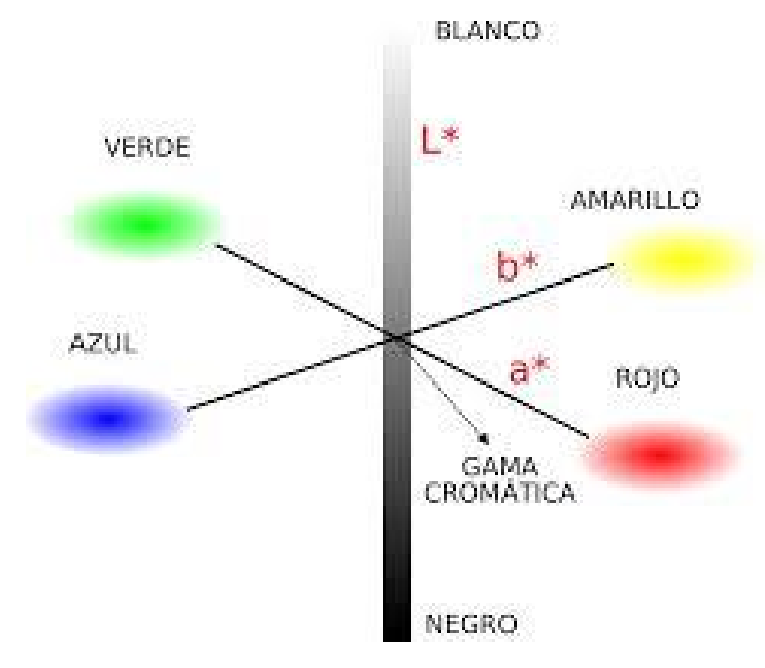

Figura 2.6. Esquema del espacio de color CIELab.

\subsubsection{Humedad}

El secado es el método más usado para la determinación de humedad de los alimentos, en el cual se calcula la pérdida en peso de agua luego del calentamiento bajo condiciones normalizadas. El contenido de humedad de las muestras se determinó de acuerdo con la norma AOAC (AOAC, 1997), para lo cual se pesó en balanza analítica (Mettler Toledo, EE.UU.) $1 \mathrm{~g}( \pm 0,001 \mathrm{~g})$ de muestra y se colocó en estufa (SanJor, Argentina) a $105^{\circ} \mathrm{C} \pm 1^{\circ} \mathrm{C}$, hasta peso constante. Todas las medidas se realizaron al menos por duplicado. El contenido de humedad se calculó de acuerdo con la siguiente ecuación, expresando los resultados en porcentaje:

Contenido de humedad \%= $((m 1-m 2) / m 1) \times 100$

Siendo $m 1$ : masa de la muestra húmeda y $m 2$ : masa de la muestra seca

\subsubsection{Determinación de actividad acuosa $\left(a_{w}\right)$}

Dentro de las características fisicoquímicas de los alimentos, la $a_{w}$ es un factor crítico que determina la vida útil de los productos. Se ha demostrado que alimentos con el mismo contenido de agua se alteran de forma distinta, por lo que se deduce que 
la cantidad de agua no es por sí sola una herramienta indicativa del deterioro. De este hecho surge el concepto de actividad acuosa $\left(a_{w}\right)$, que indica la fracción del contenido de humedad total de un producto que está libre y, en consecuencia, disponible para el crecimiento de microorganismos y para que se puedan llevar a cabo diversas reacciones químicas que afectan su estabilidad (Fennema, 2000).

La $a_{w}$ se define como la relación que existe entre la presión parcial de vapor de agua de una sustancia y la presión de vapor de agua del agua pura a la misma temperatura; siendo por esta razón un valor adimensional que varía entre 0 y 1 . En el equilibrio, la actividad de agua es igual a la presión de vapor ejercida por la sustancia en el ambiente cerrado que la rodea, donde se da una equivalencia entre la humedad relativa del aire en ese ambiente cerrado y la actividad del agua en la sustancia ensayada (Sun-Waterhouse y col., 2010).

Para la determinación se utilizó un instrumento que mide la $a_{w}$ de las muestras siguiendo la metodología de los sensores de punto de rocío. En este tipo de equipo (Fig. 2.7), la muestra se equilibra dentro de una cámara sellada que contiene un espejo que permite detectar la condensación en él. En el punto de equilibrio, la humedad relativa del aire en la cámara es el mismo que la $a_{w}$ de la muestra. Basado en el efecto Peltier, una célula fotoeléctrica y un termistor detectan el punto exacto en el que se produce la condensación y la temperatura, respectivamente.

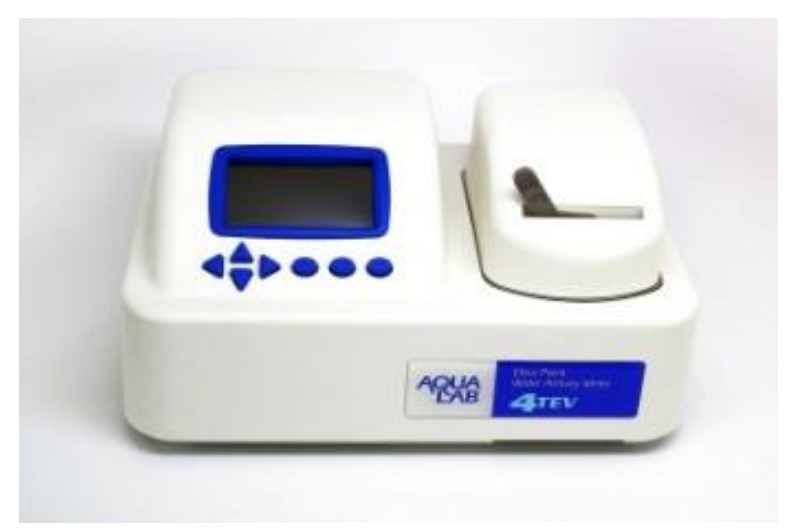

Figura 2.7. Medidor de actividad acuosa.

La determinación de la $a_{w}$ de los snacks se realizó en un equipo (Aqualab Series 4TE, EE.UU.), el cual, previo a la determinación, se calibró con una solución sobresaturada de $\mathrm{Mg}\left(\mathrm{NO}_{3}\right)_{2}\left(\mathrm{a}_{\mathrm{w}}=0,529 \pm 0,002\right)$ y luego con agua destilada $\left(\mathrm{a}_{\mathrm{w}}=1\right) \mathrm{a}$ $25^{\circ} \mathrm{C}$. De cada muestra se tomaron dos porciones para realizar la determinación por duplicado. Los resultados fueron expresados como los valores medios de la $\mathrm{a}_{\mathrm{w}}$.

\subsubsection{Capacidad de retención de agua de los geles}


La capacidad de retención de agua (CRA) es la habilidad de un producto de ligar moléculas de agua y retenerlas luego de la aplicación de una fuerza suave como la centrifugación a baja velocidad. Para la medición, se cortó un disco de gel y se colocó sobre un filtro de papel, el cual estaba soportado sobre una membrana plana de nylon (poros de 5,0 $\mu \mathrm{m}$, Micronsep, EE.UU.) mantenida en la posición media de un tubo de centrífuga de $50 \mathrm{~mL}$. La pérdida de agua se determinó pesando la muestra antes y después de centrifugarla a 120xg durante 5 min (Quéguiner y col., 1989). La CRA se expresó como el porcentaje del agua inicial remanente en el gel luego de la centrifugación.

\subsubsection{Estudio de la textura de los snacks}

Las muestras (al menos por quintuplicado) se fracturaron con el ensayo de fractura de tres puntos. El mismo se llevó a cabo en un texturómetro TA. XT2i (Stable Micro Systems Ltd, Godalming, Surrey, Reino Unido) tal como se observa en la Fig. 2.8. Se utilizó un soporte que consta de dos placas metálicas paralelas, que se ajustaron a una distancia fija $(L)$ de $2,5 \mathrm{~cm}$. La sonda utilizada posee una sección rectangular que desciende de modo de penetrar entre las dos placas paralelas del soporte. Los snacks se colocaron sobre el soporte de manera paralela a la sonda con el fin de que atraviese la mitad de éste. La fractura del material comienza cuando al descender la sonda a velocidad constante ejerce una fuerza y genera un estrés local en el material.

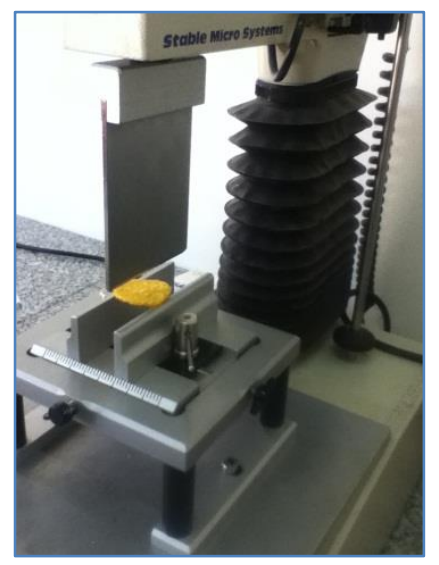

Figura 2.8. Medida de textura del snack a través del ensayo de fractura de 3 puntos en texturómetro.

Las condiciones utilizadas en el ensayo de medida de fuerza en compresión fueron velocidad de pre-ensayo: $5 \mathrm{~mm} / \mathrm{s}$, velocidad de ensayo: $1 \mathrm{~mm} / \mathrm{s}$, velocidad de pos-ensayo: $5 \mathrm{~mm} / \mathrm{s}$, distancia: $3 \mathrm{~mm}$. Se determinó la fuerza $(F)$ necesaria para la ruptura de los snacks, y la deformación $(Y)$ o distancia recorrida por la sonda antes de romperlo (Baltsavias y col., 1997). Se midió el ancho $(d)$ y el espesor (b) de los snacks 
utilizando un calibre Vernier. Con estos valores se calculó el estrés o esfuerzo de compresión y la tensión de deformación. También se determinó la tangente de la porción lineal del gráfico fuerza vs deformación, y se calculó el módulo de elasticidad en flexión o módulo de Young (Piazza y Masi, 1997).

Estrés de fractura o compresión $(\mathrm{Pa})$,

$$
\sigma=3 \mathrm{FL} / 2 \mathrm{bd}^{2}
$$

Tensión de deformación o de fractura (adim.)

$$
\varepsilon=6 \mathrm{bY} / \mathrm{L}^{2}
$$

Módulo de elasticidad en flexión (módulo de Young) (Pa),

$$
E=\mathrm{L}^{3} \mathrm{~m} / 4 \mathrm{db}^{2}
$$

Dónde: $F, m, Y$, se extraen de la curva $F$ vs. Distancia

$\mathrm{F}$ es la fuerza máxima $(\mathrm{N})$, relacionada con la dureza del producto.

$L$ es la distancia entre soportes ( $\mathrm{mm})$.

Y es la deformación ( $\mathrm{mm}$ ).

$\mathrm{m}$ : tangente de la porción lineal $(\mathrm{N} / \mathrm{mm})$.

$\mathrm{d}$ y b: ancho y espesor de los snacks, respectivamente ( $\mathrm{mm})$.

\subsubsection{Determinación de las características texturales de los geles}

Uno de los ensayos multivariable más utilizados en el estudio de la textura de un gel es el de resistencia a la penetración (ensayo de ruptura). En él se penetra una muestra, preferentemente de dimensiones prefijadas, hasta su ruptura o hasta una distancia predeterminada. Este método imita las grandes deformaciones que tienen lugar durante la masticación del alimento, hasta que se produce la ruptura de éste. A modo de ejemplo, en la Fig. 2.9 se muestra una curva típica de esfuerzo de corte vs. deformación de un gel por efecto de su compresión hasta ruptura. 


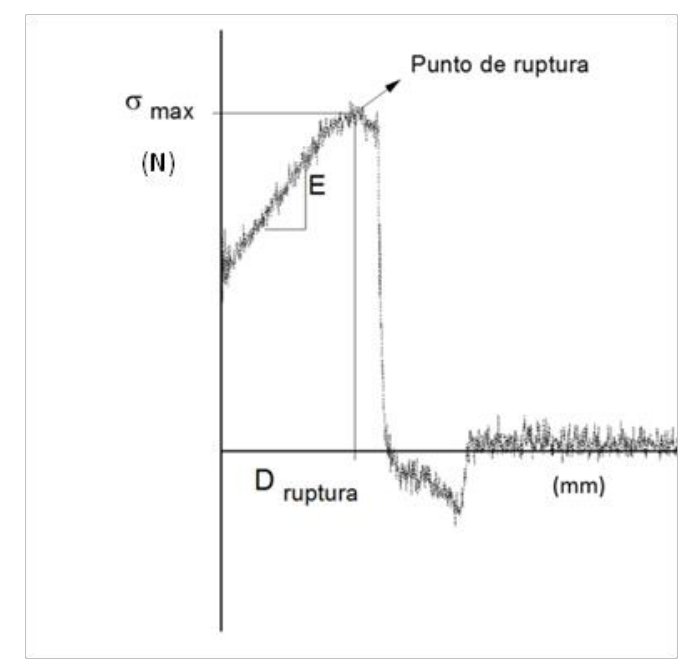

Figura 2.9. Curva típica de esfuerzo $(\sigma)$ vs. deformación (D) obtenida por compresión de un gel.

Se observa la forma gráfica de obtención de los parámetros: $\sigma_{\text {máx }}$ y $D_{\text {ruptura }}$ que corresponden al esfuerzo máximo y a la deformación en el punto de ruptura de la muestra, respectivamente, y E que corresponde al módulo de Young. Este módulo se calculó como la pendiente de la curva $\sigma$ vs. D, en la zona recta inicial antes del punto de ruptura. El esfuerzo y la deformación en el punto de ruptura indican la fuerza del gel y la elasticidad, respectivamente y el módulo de Young se relaciona con la rigidez estructural de la muestra.

El ensayo se llevó a cabo en el texturómetro (Texture Analyser T2i TA. XT2iStable Micro Systems, Reino Unido) donde una muestra de los geles de dimensiones prefijadas (altura $20 \mathrm{~mm}$, diámetro $17,5 \mathrm{~mm}$ ) se penetró hasta su ruptura. El equipo se utilizó con una celda de carga de $25 \mathrm{Kg}$. Se empleó una sonda P/0,5 R de 1,2 cm de diámetro (Fig 2.10) la cual penetraba la muestra por el centro hasta un $20 \%$ de su altura con fuerza y velocidad de pre-ensayo, ensayo y post-ensayo constantes $(0,98 \mathrm{~N}$; $5,0 \mathrm{~mm} / \mathrm{s} ; 1,0 \mathrm{~mm} / \mathrm{s}$ y $5,0 \mathrm{~mm} / \mathrm{s}$, respectivamente).

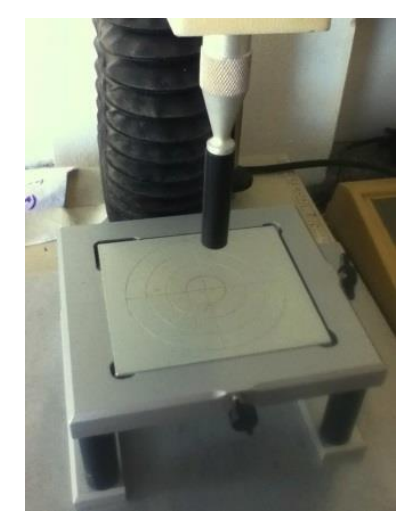

Figura 2.10. Sonda para ensayo de penetración en texturómetro. 
Las determinaciones se realizaron al menos por triplicado. Las curvas de fuerza en función del tiempo o de la deformación se registraron automáticamente mediante el software Texture Expert Exceed instalado en una computadora conectada al equipo.

\subsubsection{Análisis reológico de los geles}

La reología es la ciencia que estudia la deformación y el flujo de materia, es decir, la relación entre el esfuerzo que se aplica a un material y la deformación que sufre el mismo. En el área de alimentos, la información que brindan los datos reológicos es indispensable en el diseño de procesos y en la evaluación de calidad del producto. Por ejemplo, es de utilidad en cálculos de requerimientos de bombeo (dimensiones de tuberías y válvulas, mezcladoras), control instrumental de materia prima, elaboración del producto y seguimiento durante el almacenamiento. Además, a través de la reología se puede evaluar la calidad preferida por el consumidor a través de correlaciones entre las medidas reológicas y las pruebas sensoriales (Steffe, 1996).

Por otro lado, la reología permite elucidar la estructura o la composición de alimentos y analizar los cambios estructurales que ocurren durante el procesamiento. En el caso de geles de proteínas de lactosuero es importante determinar su comportamiento viscoelástico, analizando las componentes viscosa (módulo viscoso o de pérdida G') y sólida (módulo elástico o de almacenamiento G') por separado a través de medidas oscilatorias en un reómetro. En este tipo de ensayos se aplica una deformación oscilatoria de amplitud constante y se mide como señal el esfuerzo de corte de respuesta. G' es el cociente entre el esfuerzo que está en fase con la deformación y la deformación, mientras que G" es el cociente entre el esfuerzo que está desfasado $\pi / 2$ con la deformación y la deformación. También es posible obtener la viscosidad compleja $\left(\eta^{*}\right)$, la cual es una medida de la resistencia de la muestra a ser deformada. Este análisis permite conocer el efecto de ingredientes o de variables de proceso como temperatura, presión, $\mathrm{pH}$ del medio, tiempo de almacenamiento, entre otras, sobre el comportamiento de los geles (van Vliet y col., 2004).

Los ensayos se llevaron a cabo por triplicado en un reómetro Haake RS 600 (Thermo Scientific, Karlsruhe, Alemania), utilizando un sensor de platos paralelos (Fig. 2.11) con una separación de $1 \mathrm{~mm}$ entre ambos platos. Las muestras (discos de $1 \mathrm{~mm}$ de espesor) se colocaron sobre el plato inferior termostatizado a $20^{\circ} \mathrm{C} \pm 0,1^{\circ} \mathrm{C}$ controlado por un baño de agua circulante Haake (Karlsruhe, Alemania). Luego de cargar la muestra se esperó 5 min para que la misma relaje y alcance la temperatura experimental. El equipo se controló con el software Rheowin 4.0 Job Manager y los datos experimentales fueron analizados con el software Rheowin 4.0 Data Manager. 


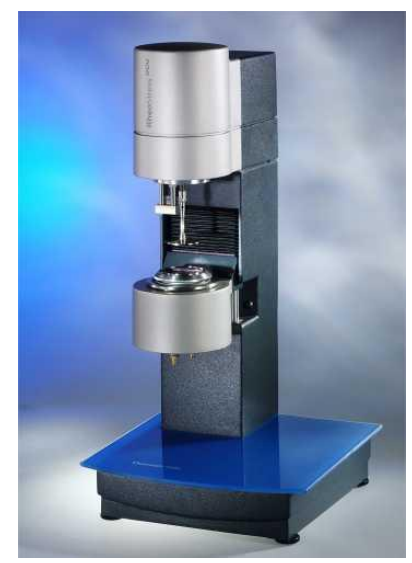

Figura 2.11. Reómetro oscilatorio.

El rango de viscoelasticidad lineal, es decir, el rango donde la relación entre el esfuerzo y la deformación sólo es función del tiempo o de la frecuencia (no depende de la magnitud del esfuerzo aplicado), se determinó midiendo el módulo complejo o dinámico $G^{*}$ (módulo del vector obtenido como suma de las contribuciones de los módulos G' y G') en función de la deformación (barrido de deformación). En base a estos resultados, los barridos de frecuencia de las muestras se realizaron a la misma deformación, dentro de los límites de la linealidad. Para la caracterización viscoelástica de las muestras se realizó un barrido de frecuencias $(0,05-100 \mathrm{hz})$ donde se analizó la variación de G', G” y $\eta^{*}$ en función de la frecuencia de oscilación (f).

\subsubsection{Microscopía electrónica de barrido (SEM)}

La microscopía electrónica de barrido (SEM en inglés, scanning electron microscopy) permite conocer la morfología de la superficie de las muestras a estudiar, además de detectar la posible agregación de las partículas y determinar el tamaño de éstas. Esta técnica ha sido empleada para examinar las propiedades de superficie y la estructura de un gran número de materiales en el campo de alimentos. Emplea un haz de electrones en lugar de un haz de luz visible, obteniéndose una resolución mucho mayor que la alcanzada con microscopía óptica. En un microscopio electrónico de barrido los electrones son emitidos desde un filamento de tungsteno (cátodo) y acelerados en un campo eléctrico. Los electrones son enfocados por un condensador y una lente objetivo electromagnética sobre la muestra cubierta por un metal pesado (oro u osmio). Las muestras deben encontrarse libres de humedad y sometidas a alto vacío.

Previo a las mediciones, las muestras de los snacks fueron liofilizadas para eliminarles completamente la humedad. Porciones pequeñas de dichas muestras se 
recubrieron con oro y se observaron en un microscopio de barrido electrónico FEI Quanta 200 (Oregon, EE.UU), empleando un voltaje de aceleración de 15kV.

\subsubsection{Microscopía confocal láser de barrido}

La microscopía confocal láser de barrido (CSLM en inglés, confocal scanning laser microscopy) permite obtener imágenes de mayor nitidez y contraste, mayor resolución vertical y horizontal y además permite obtener secciones ópticas de la muestra a partir de las cuales se logra obtener una reconstrucción tridimensional de la misma. El principio del funcionamiento del microscopio confocal se basa en la existencia de dos diafragmas, uno entre la fuente de luz y el objetivo y el otro entre el objetivo y el detector. Ambos diafragmas deben estar perfectamente alineados de forma que el segundo de ellos únicamente deje llegar al detector la luz procedente del plano focal. La utilización de un láser como fuente de luz permite focalizar la iluminación en una región muy pequeña de la muestra y con una gran intensidad (Martínez, 2013).

Para la preparación de las muestras, una porción de las pastas de los snacks se laminó sobre un portaobjeto e inmediatamente se cubrió con la solución que contenía el fluoróforo Rodamina B $(0,001 \%)$ en agua destilada para el marcado no covalente. La Rodamina B se une preferentemente a proteínas, pero también puede unirse al almidón (en menor grado) (Silva y col., 2013). Luego, la muestra se colocó en un horno durante $5 \mathrm{~min}$ a $160^{\circ} \mathrm{C}$, se dejó enfriar y se reservó en oscuridad hasta su análisis. Las muestras se prepararon por duplicado.

La medida se realizó en un microscopio confocal de barrido láser LEICA TCS SP5 (Leica Microsystems, Baden-Württemberg, Alemania). Se utilizó el láser de luz visible $\mathrm{He} / \mathrm{Ne}$ a una potencia del $30 \%$ y el lente objetivo Leica $63 \times 1,4$ de apertura numérica con un zoom de 1,7. Las longitudes de onda de excitación y emisión fueron de 568nm y $625 \mathrm{~nm}$ respectivamente.

\subsubsection{Análisis de composición química}

Se determinó el contenido de proteínas totales y de lípidos de las diferentes muestras, como se describe en los siguientes apartados. El contenido de humedad de las mismas se determinó como se describió en la sección 2.4.2. Los carbohidratos totales se calcularon por diferencia gravimétrica respecto a los otros análisis realizados. 


\subsubsection{Proteínas totales}

Se utilizó el método de Kjeldahl-Arnold-Gunning (AOAC 960.52, 1997), el cual se basa en la destrucción de la materia orgánica de la muestra por acción de ácido sulfúrico concentrado.

Se colocó la cantidad adecuada de muestra (de acuerdo con el contenido estimado de nitrógeno) en tubo de digestión, se agregó $10 \mathrm{~g}$ de $\mathrm{K}_{2} \mathrm{SO}_{4} \circ \mathrm{Na}_{2} \mathrm{SO}_{4}$ anhidro, $1 \mathrm{~g}$ de $\mathrm{CuSO}_{4} .5 \mathrm{H}_{2} \mathrm{O}$ (o dos cucharaditas de té de la mezcla catalizadora ya preparada), plato poroso y $20 \mathrm{~mL}$ de $\mathrm{H}_{2} \mathrm{SO}_{4}$ conc. Se calentó la mezcla suavemente hasta que cesó el desprendimiento de espuma; luego se calentó enérgicamente hasta completar la digestión de la materia orgánica (no se observan partículas carbonosas sin oxidar y el líquido queda translúcido y de color débilmente verdoso o azul-verdoso).

Luego de la digestión (aproximadamente entre 1 y 2 h), se dejó enfriar y se conectó el tubo a un refrigerante del equipo destilador (Unidad de destilación K-350, Büchi, Alemania), se agregó la cantidad de $\mathrm{NaOH} 32 \% \mathrm{p} / \mathrm{v}$ necesaria para neutralizar la cantidad de ácido de la muestra (el volumen de hidróxido debe neutralizar los $20 \mathrm{~mL}$ de $\mathrm{H}_{2} \mathrm{SO}_{4}$ conc. y además se adicionan $5 \mathrm{~mL}$ en exceso para alcalinizar la muestra). Luego se colocó un Erlenmeyer con $50 \mathrm{~mL}$ de $\mathrm{H}_{3} \mathrm{BO}_{3} 4 \% \mathrm{p} / \mathrm{v}$ (sobre el cual se va a recoger el $\mathrm{NH}_{3}$ destilado) y gotas del indicador Mortimer (16 mg de rojo de metilo y 83 $\mathrm{mg}$ de verde de bromocresol en $100 \mathrm{~mL}$ de etanol), cuidando que el extremo del refrigerante quede sumergido en la solución. Se destiló hasta llegar a aproximadamente $150 \mathrm{~mL}$ en el Erlenmeyer colector (los primeros $120 \mathrm{~mL}$ de destilado contienen generalmente la totalidad del $\mathrm{NH}_{3}$ ). El destilado recogido se tituló con solución de $\mathrm{H}_{2} \mathrm{SO}_{4}$ 0,0858 $\mathrm{N}$ valorada hasta viraje del indicador a su color original. El contenido de proteínas totales se calculó como gramos de nitrógeno total.

Proteína $(\%)=($ Vmuestra - Vblanco $) \times \mathrm{NH}_{2} \mathrm{SO}_{4} \times 14 \times \mathrm{f} \times 100 /$ masa muestra $\quad$ Ec. 2.5

Donde Vmuestra y Vblanco son los volúmenes $(\mathrm{L})$ de la muestra y el blanco, respectivamente, $\mathrm{NH}_{2} \mathrm{SO}_{4}$ es la Normalidad (Equivalentes/L) de la solución de ácido sulfúrico y f es el factor de conversión (g proteína/g nitrógeno) utilizado para obtener el contenido proteico, cuyo valor fue de 5,7 .

\subsubsection{Lípidos}

Se utilizó el método de Soxhlet (AOAC 945.16, 1997) que se basa en el proceso de transferir los componentes parcialmente solubles de un sólido a la fase líquida utilizando un extractor Soxhlet. El sólido se coloca en un cartucho de papel de filtro 
que luego se coloca en la cámara principal del extractor Soxhlet. El solvente (calentado a reflujo) viaja a la cámara principal y los componentes parcialmente solubles se transfieren lentamente al solvente. Esta determinación suele denominarse extracto etéreo, pues además de los lípidos se extraen otros compuestos solubles en el solvente.

En un cartucho de papel de filtro se colocó la muestra seca y pesada (proveniente de la determinación de humedad), y el cartucho se introdujo en el tubo extractor. Se taró el balón del equipo y se conectó al mismo. Por la parte superior del tubo extractor se agregó el solvente adecuado (éter de petróleo, rango $30-65^{\circ} \mathrm{C}$ ) hasta que descarga el sifón, adicionando además alrededor de la mitad del contenido del tubo extractor. Se calentó durante $2 \mathrm{~h}$ aproximadamente, ya que deben producirse al menos 7 ciclos de llenado y sifonado del tubo extractor. Luego se desconectó el balón, teniendo la precaución de apagar la fuente calorífica un instante antes que accione el sifón, se eliminó el resto del solvente sacando el cartucho y recogiendo el éter en el tubo extractor para luego recuperarlo, luego se secó totalmente en estufa a $35^{\circ} \mathrm{C}$ y se pesó en balanza analítica. El contenido de lípidos se calculó como:

$$
G(\%)=m_{2}-m_{1} / M \times 100
$$

Donde $\mathrm{m}_{2}$ : masa balón con grasa, $\mathrm{m}_{1}$ : masa balón, M: masa muestra.

\subsubsection{Cenizas}

Se pesó la muestra en balanza analítica a la décima de mg dentro de una cápsula de porcelana (previamente calcinada en mufla a $500-550^{\circ} \mathrm{C}$ (rojo sombra), enfriada en desecador y pesada a temperatura ambiente). En el caso de las muestras sólidas, se carbonizó la cápsula con la muestra sobre triángulo de pipas o tela metálica hasta residuo carbonoso. Luego se calcinó en mufla a $500-550^{\circ} \mathrm{C}$ hasta cenizas blancas o de color gris claro y peso constante. Se enfrió en desecador y se pesó al alcanzar la temperatura ambiente. En el caso de las muestras líquidas, se evaporó hasta sequedad a baño María y luego se procedió como se describió para muestras sólidas. Esta determinación se realizó por duplicado. El contenido de cenizas se calculó como:

$$
\text { Cenizas totales }(\%)=\left(m_{2}-m_{0}\right) /\left(m_{1}-m_{0}\right) \times 100
$$

Donde $\mathrm{m}_{2}$ : masa cápsula con cenizas, $\mathrm{m}_{1}$ : masa cápsula con muestra, $\mathrm{m}_{0}$ : masa cápsula vacía. 


\subsubsection{Determinación de pH}

Se utilizó un pH-metro (Altronix TPA-V PY41, EE.UU.) y soluciones reguladoras de $\mathrm{pH} 4$ y pH 7 para realizar la calibración del electrodo. Para proceder a la medición se sumergió el pH-metro en la solución a medir y se leyó el valor del pH en la pantalla del equipo. Las medidas se realizaron por duplicado en el líquido de cocción del maíz sin y con los sucesivos agregados de extracto de yerba mate, $\mathrm{CPL}$, harina de lino y miel.

\subsubsection{Determinación del contenido de polifenoles y flavonoides totales y actividad antioxidante (DPPH y ABTS)}

Las determinaciones se realizaron en el extracto de yerba mate, el líquido de cocción (claro de maíz), los snacks y los geles, a fin de determinar el aporte a la actividad antioxidante de cada uno de los componentes utilizados en la formulación.

Con el objetivo de obtener una solución límpida y clara para el análisis, el líquido de cocción del maíz se centrifugó primero a $3905 \mathrm{~g}$ durante 5 min y se separó el sobrenadante, luego se volvió a centrifugar a $7810 \mathrm{~g}$ durante otros $5 \mathrm{~min}$. Se reunieron los sobrenadantes y se utilizaron en los respectivos análisis.

En el caso de los snacks y de los geles fue necesario un procedimiento previo de extracción de los compuestos antioxidantes, el cual se describe a continuación:

\subsubsection{Método de extracción de polifenoles y flavonoides de las matrices de snacks y geles}

Se siguió la técnica descripta por Boateng y col. (2008) con pequeñas modificaciones. Una muestra de $5 \mathrm{~g}$ se extrajo con $50 \mathrm{~mL}$ de etanol acuoso (etanol: agua; 80:20 v/v), durante $2 \mathrm{~h}$ a temperatura ambiente y con agitación constante. La muestra se centrifugó a $7810 \mathrm{~g}$ durante $20 \mathrm{~min}$ y se removió el sobrenadante, reservándolo. La extracción descripta se repitió dos veces y los sobrenadantes se reunieron en un frasco de vidrio color ámbar, para evitar la exposición prolongada de las muestras al efecto de la luz. Luego se almacenaron en cámara a $0^{\circ} \mathrm{C}$, hasta el momento de su análisis.

\subsubsection{Polifenoles totales}

Para la determinación del contenido de polifenoles totales se utilizó el método de Folin-Ciocalteu el cual se basa en la oxidación de los grupos fenólicos de la muestra con los ácidos fosfotúngstico y fosfomolíbdico del reactivo (Singleton y col., 1999). Como resultado de la reacción se forma un complejo verde azulado, el cual tiene un máximo de absorbancia entre 725 y $750 \mathrm{~nm}$. 
En el análisis se tomaron $0,2 \mathrm{~mL}$ de muestra y se colocaron en un tubo de ensayo conteniendo $2 \mathrm{~mL}$ de $\mathrm{Na}_{2} \mathrm{CO}_{3}$ al 2\%p/v (Anedra, Argentina), se dejó reposar durante 2 min y a continuación se agregaron $0,2 \mathrm{~mL}$ del reactivo de Folin-Ciocalteu (1:1) (Anedra, Argentina). Se agitó mediante vórtex y, luego de un tiempo de reacción de 30 min, se procedió a la medida de absorbancia a $725 \mathrm{~nm}$ en un espectrofotómetro (Shimadzu Double Bean Spectrophotometer UV-150-02, Seisakusho Ltd., Kyoto, Japón). Se realizaron las determinaciones en muestras por triplicado. Para calcular la concentración se utilizó la ley de Lambert-Beer:

$$
A=\varepsilon . b . C
$$

Donde $A$ es la absorbancia medida, $\varepsilon$ es el coeficiente de extinción determinado a partir de la pendiente de la curva de calibración $\left(\mathrm{mL} \cdot \mathrm{cm}^{-1} \cdot \mathrm{mg}^{-1}\right)$, b es el camino óptico $(1 \mathrm{~cm})$ y $\mathrm{C}$ es la concentración de la muestra. Se realizó la curva de calibración con el patrón de ácido clorogénico $(0,025-0,20 \mathrm{mg} / \mathrm{mL}, A=3,97 \times \mathrm{C})$ ya que es el compuesto mayoritario en la yerba mate de acuerdo con estudios cuantitativos de HPLC (Chandra y col., 2004). Los resultados del contenido de polifenoles totales se expresaron como mg de ácido clorogénico equivalente por g de muestra (mg AC $/ \mathrm{g}$ ).

\subsubsection{Flavonoides totales}

Esta determinación se llevó a cabo a través de la técnica del tricloruro de aluminio (Socha y col., 2009). El $\mathrm{AlCl}_{3}$ anhidro forma quelatos con flavonoides ortodihidroxilados, 3-hidroxilados y 5-hidroxilados en medio básico. Estos quelatos presentan una coloración rosada con un máximo de absorción a 510nm indicando la presencia de flavonoides.

Para el análisis se tomaron $1,5 \mathrm{~mL}$ de muestra y se colocaron en un tubo de ensayo, se agregaron $0,1 \mathrm{~mL} \mathrm{NO}{ }_{2} \mathrm{Na}(15 \% \mathrm{p} / \mathrm{v}), 0,15 \mathrm{~mL} \mathrm{AlCl}_{3}(10 \% \mathrm{p} / \mathrm{v}), 1,0 \mathrm{~mL}$ de $\mathrm{NaOH}(4 \% \mathrm{p} / \mathrm{v})$. Se homogeneizó con un vórtex se dejó reposar 2 min y se midió la absorbancia a $510 \mathrm{~nm}$ en el espectrofotómetro. Luego se calculó la concentración a partir de la curva de calibración como se indicó en la sección anterior, utilizando catequina como patrón $(1 / 10 \mathrm{mg} / \mathrm{L}, A=3,34 \times \mathrm{C}+0,04)$. Los valores de flavonoides totales se expresaron en $\mathrm{mg}$ de catequina equivalente por $\mathrm{g}$ de muestra (mg Cat/g).

\subsubsection{Actividad antioxidante por método DPPH}

La actividad antioxidante fue determinada usando el radical 2,2-difenil-1-picril hidracilo (DPPH•) como radical libre. En su forma estable el radical absorbe a $515 \mathrm{~nm}$, pero luego de ser reducido por un antioxidante $(\mathrm{AH}) \mathrm{u}$ otra especie radical $(\mathrm{R} \bullet)$, la absorción desaparece según la siguiente reacción:

$$
\mathrm{DPPH} \bullet+\mathrm{AH} \rightarrow \mathrm{DPPH}-\mathrm{H}+\mathrm{A} \bullet
$$




$$
\mathrm{DPPH} \bullet+\mathrm{R} \bullet \rightarrow \mathrm{DPPH}-\mathrm{R}
$$

La disminución de la concentración del $\mathrm{DPPH} \bullet$ representa la capacidad antioxidante total del compuesto ensayado.

El análisis se realizó de acuerdo con la técnica descripta por Socha y col. (2009) con leves modificaciones. Se colocaron en un tubo de ensayo $0,75 \mathrm{~mL}$ de muestra con 2,25 mL de solución de $\mathrm{DPPH}$, la concentración de $\mathrm{DPPH}$ fue de $0,1 \mathrm{mM}$ de absorbancia alrededor de 0,9. Como muestra control se utilizó la misma mezcla de reacción, pero reemplazando la muestra por agua destilada. Se dejó 20 min en oscuridad y luego se midió la absorbancia a 515nm en el espectrofotómetro. Los resultados se expresaron como porcentaje de inhibición del radical DPPH, realizando el cálculo a partir de las absorbancias de la muestra y del control, de acuerdo con la siguiente ecuación:

$$
\operatorname{IDPPH}(\%)=\left(A_{\text {control }}-A_{\text {muestra }}\right) / A_{\text {control }} \times 100
$$

\subsubsection{Actividad antioxidante por método ABTS}

El radical catiónico ABTS+ (ácido 2,2'-azino-bis (3-etilbenzotiazolin-6-sulfónico)) generado por la reacción entre el ABTS y el persulfato de potasio es de un color azulado intenso con un máximo de absorción a 734nm. La medición se basa en una disminución del color por parte de los compuestos de prueba al reaccionar directamente con el ABTS+. El grado de decoloración se determina en función de la concentración y del tiempo y se calcula relativo a un estándar.

Para el análisis se realizó la técnica descripta por $\operatorname{Re}$ y col. (1999) con leves modificaciones. Se colocaron $0,05 \mathrm{~mL}$ de muestra en un tubo de ensayo y se agregó 1,0 mL de solución de ABTS+ de absorbancia alrededor de 0,7 ( $\left.\mathrm{A}_{\mathrm{ABTS}}\right)$. Se realizó un registro de la absorbancia cada 1 min hasta que se estabilizó la medida, tomando este último valor como final $\left(A_{m}\right)$. Luego se calculó la concentración a partir de la curva de calibración ( $\left.A_{A B T S}-A_{m}=0,1059 \times C+0,0173\right)$, utilizando Trolox como patrón y los resultados se expresaron como $\mu \mathrm{mol}$ Trolox/g muestra.

\subsubsection{Análisis sensorial de los snacks elaborados}

El análisis sensorial evalúa las propiedades organolépticas de los productos, es decir, todo lo que se puede percibir por los sentidos y determinar su aceptación por el consumidor (Barda, 2011). Dentro de los ensayos afectivos o de aceptabilidad se encuentran entre otros, los siguientes métodos: comparación de a pares, ordenamiento de preferencia, escala hedónica. En el primero se busca comparar un producto con otro, ya sea para el mejoramiento de un producto o buscando paridad 
con la competencia. Este método fuerza una elección de un producto sobre el otro sin indicar si fueron aceptables o no. En el ordenamiento de preferencia, el objetivo es comparar la preferencia de más de dos muestras. También se utiliza cuando se quiere ordenar una serie de muestras según un mismo atributo. Por su parte, el método de escala hedónica permite saber cuál es el grado de aceptabilidad sensorial de un producto. La persona le asigna un puntaje dentro de la escala que se le presenta a un atributo en especial del alimento o a la preferencia global del mismo (Hough y col., 2006).

La evaluación sensorial de los snacks y de los postres se realizó con un panel no entrenado de 50 personas. Se evaluaron características de sabor y textura empleando escalas hedónicas no estructuradas ancladas en los extremos y en el medio. Para la evaluación, las muestras se ordenaron al azar y se asignó un código de tres dígitos a cada una (Fig. 2.12). Como neutralizante, se utilizó agua a temperatura ambiente para que los evaluadores se enjuagaran la boca entre cada prueba de muestra.
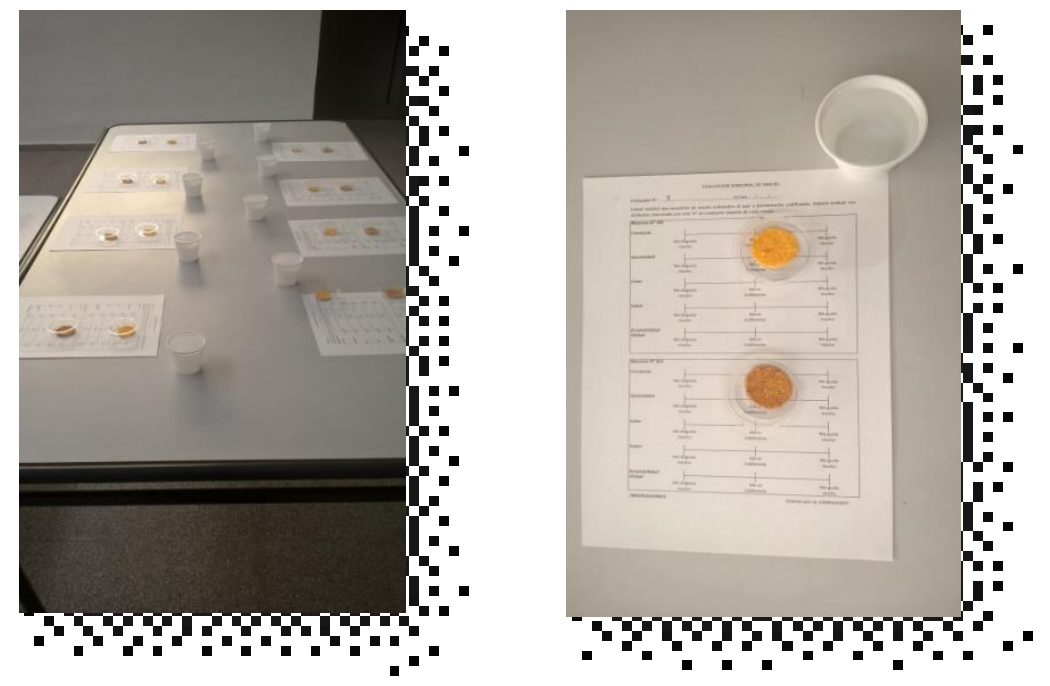

Figura 2.12. Fotografías mostrando la presentación de las muestras a los panelistas.

\subsection{Análisis estadístico}

Todos los ensayos se realizaron al menos por duplicado y los datos obtenidos se evaluaron estadísticamente a través del programa InfoStat (versión 2014, Universidad Nacional de Córdoba, Argentina). Se realizó análisis de varianza (ANOVA) y se aplicó el test de Fisher (LSD) con un nivel de confianza del 95\% $(\alpha=0,05)$ para la comparación de medias. 


\section{Capítulo 3}

\section{Formulación y caracterización de los snacks}




\subsection{Formulación del snack base y determinación de las condiciones óptimas de procesamiento}

El desarrollo del producto tipo snack comenzó con el análisis de la formulación y de las condiciones de proceso, a fin de establecer la relación maíz:agua, el tiempo y la velocidad de calentamiento del maíz óptimos para obtener una pasta laminable. Las proporciones de maíz y agua ensayadas, 1:8 y 1:10, se determinaron teniendo en cuenta el exceso de agua necesario para la gelatinización del almidón contenido en el maíz. La cantidad de agua afecta el proceso de gelatinización, pero su influencia se ve menos marcada cuando la velocidad de calentamiento es menor, pues se permite la aproximación hacia el equilibrio termodinámico (Coral, 2010). Por ello, se ensayaron velocidades de calentamiento bajas $\left(10-20^{\circ} \mathrm{C} / \mathrm{min}\right)$, buscando la mejor relación entre rendimiento y manejo de la pasta en su laminado. En la Fig. 3.1a se observa el rendimiento obtenido luego de $60 \mathrm{~min}$ de cocción a $10^{\circ} \mathrm{C} / \mathrm{min}$ para las diferentes relaciones maíz:agua empleadas.
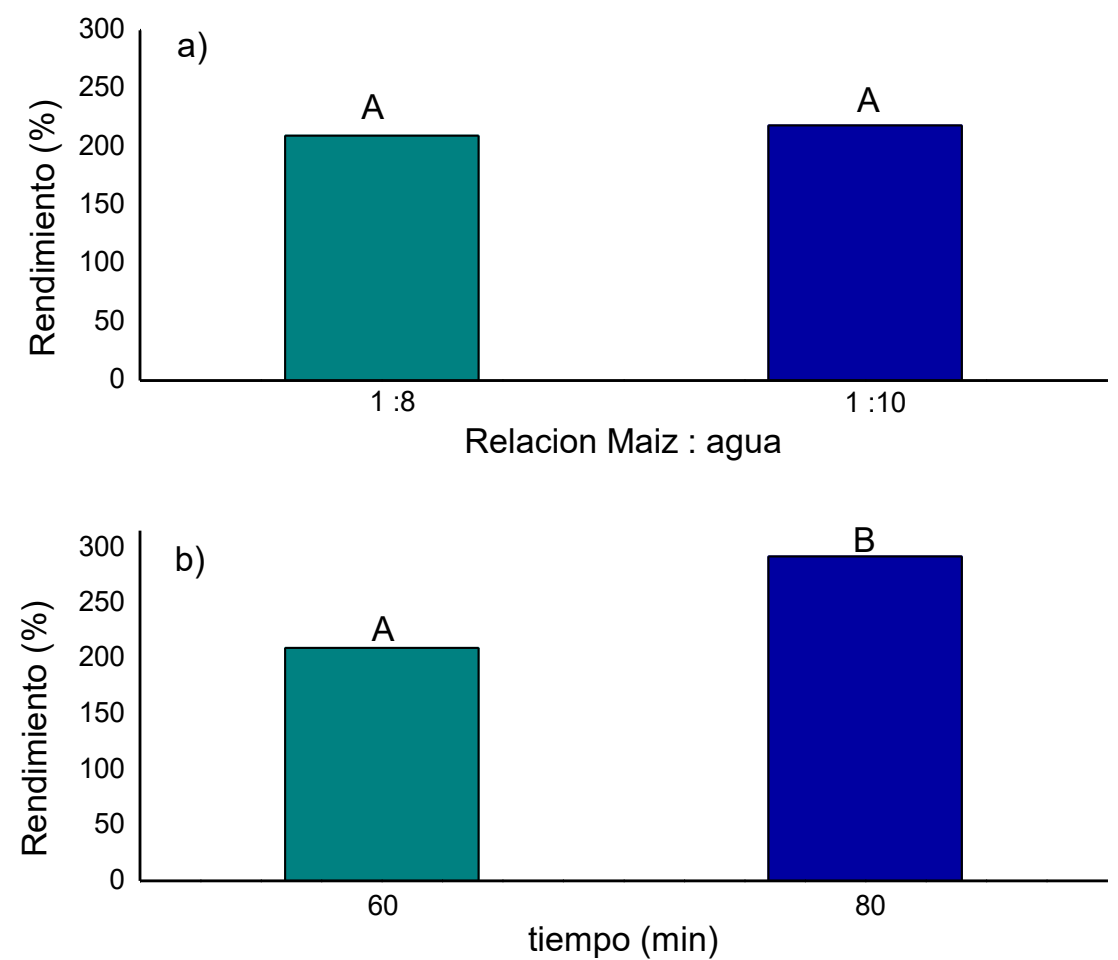

Figura 3.1. a) Rendimiento de la pasta obtenida a un tiempo de cocción de $60 \mathrm{~min}$ a $10^{\circ} \mathrm{C} / \mathrm{min}$ utilizando diferentes relaciones maíz: agua. b) Rendimiento de la pasta obtenida con una relación maíz: agua 1:8 a 60 y 80 min de cocción.

Barras con una letra común en un mismo grafico no son significativamente diferentes $(p>0,05)$.

Se observó una tendencia hacia un mayor rendimiento de la pasta utilizando mayores proporciones de agua respecto al maíz (Fig. 3.1a). Sin embargo, dichas 
diferencias no fueron significativas y luego de $60 \mathrm{~min}$ de calentamiento los granos de maíz duplicaron su peso absorbiendo aproximadamente un $55 \%$ de agua, independientemente de la relación maíz:agua utilizada. Respecto al tiempo de calentamiento, las pastas de maíz obtenidas luego de 60 min de cocción presentaron una textura adecuada que permitió un buen laminado y moldeado de los snacks. A fin de incrementar el rendimiento de la pasta se procedió a la cocción del maíz durante 80 min, observándose que al cabo de ese tiempo los granos de maíz habían absorbido todo el contenido de agua, obteniendo así un mayor rendimiento (Fig. 3.1b).

En el presente trabajo se desea aprovechar el agua de cocción para elaborar otro alimento, por lo que podría utilizarse una relación alta entre maíz y agua. Sin embargo, en ese caso y teniendo en cuenta que parte del almidón contenido en el grano de maíz es lixiviado al agua de cocción (Fig. 3.2), éste quedaría diluido en una mayor cantidad de agua que luego habría que evaporar para lograr una concentración de almidón adecuada que pueda gelificar. Por ello, se seleccionó como base para los siguientes ensayos la relación maíz:agua 1:8 en la cual existe un compromiso entre la cantidad de líquido generado en la cocción y la concentración de almidón en dicho líquido.
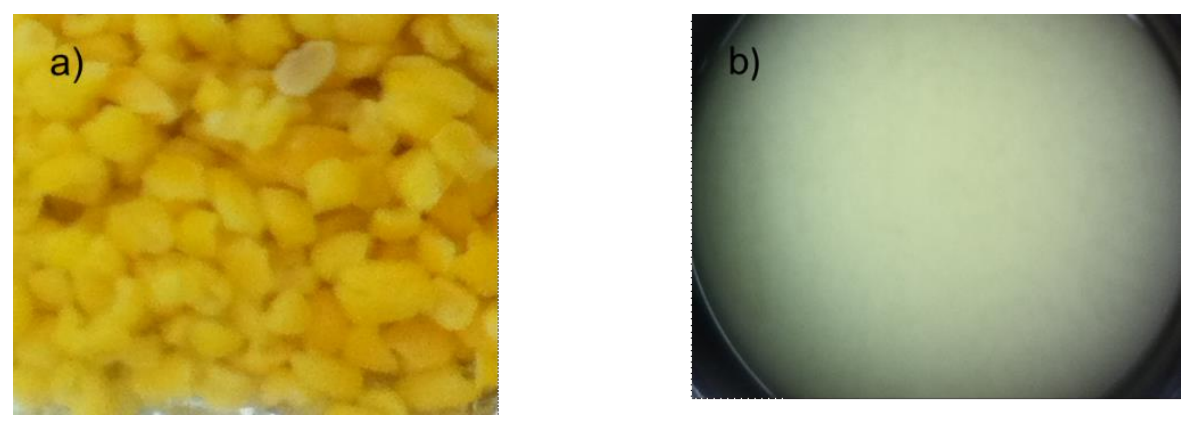

Figura 3.2. Fotografías de a) pasta de maíz, b) líquido de cocción

En algunos procesos, como en la elaboración de arepas, luego de la cocción de los granos de maíz se realiza una operación de lavado de los granos hidratados. De esta forma se pretende arrastrar la amilosa que pueda quedar adherida a los granos, ya que, de no ser retirada, puede aumentar la rigidez de la arepa como producto terminado y hacerlo menos resistente a los esfuerzos a los que se somete durante el transporte y el manejo por parte del consumidor (García y col., 2006). En el presente caso, no es conveniente dicha operación de lavado de los granos hidratados ya que se pretende dar rigidez a la pasta para obtener el snack.

Si bien con un tiempo de calentamiento de 80 min se obtuvo mayor rendimiento, las pastas resultantes fueron difíciles de laminar debido a su alta adhesividad $(0,86 \pm 0,07 \mathrm{~N} . \mathrm{s})$, comparada con la obtenida con 60 min de calentamiento $(0,12 \pm 0,01$ 
N.s). Estos comportamientos quedaron evidenciados en los perfiles de textura de las pastas (Fig. 3.3).
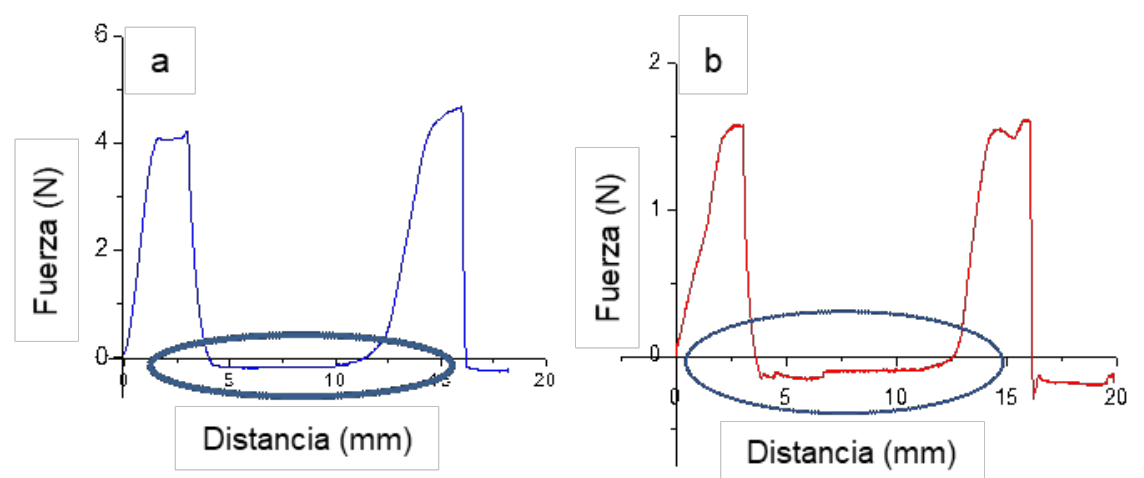

Figura 3.3. Perfiles de textura de pastas de maíz y agua (1:8) sometidas a calentamiento durante a) $60 \mathrm{~min}$ y b) $80 \mathrm{~min}$.

En cuanto a la velocidad de calentamiento, un incremento a $20^{\circ} \mathrm{C} / \mathrm{min}$ no condujo a mejoras en la textura de las pastas ni en su rendimiento. Por lo tanto, se seleccionó una relación maíz: agua de 1:8 y un tiempo de cocción de 60 min a una velocidad de $10^{\circ} \mathrm{C} / \mathrm{min}$ como las condiciones óptimas para obtener una pasta con textura adecuada para el laminado y moldeado de los snacks.

A fin de optimizar la formulación desde el punto de vista nutricional, se ensayaron 3 niveles de concentración de harina de lino, al 1, 3 y 5\% p/p respecto al peso de maíz y se evaluó su incorporación en dos etapas del proceso, por un lado, junto al agua de cocción del maíz y por otro en la pasta cocida (Fig. 2.3a y Fig. 2.3b, sección Materiales y métodos, respectivamente). Cuando se agregó al agua de cocción se halló que la actividad acuosa de los snacks resultantes $(0,7-0,8)$ fue significativamente mayor ( $p \leq$ $0,05)$ que en aquellos donde se había mezclado con la pasta cocida $(0,4-0,6)$. Este incremento en la $a_{w}$ puede deberse a la capacidad de los mucílagos presentes en la fibra de la harina de lino para absorber agua, lo cual condujo al desarrollo de hongos luego de 7 días de almacenamiento a $20^{\circ} \mathrm{C}$. Además, otro inconveniente que se observó en la incorporación en el momento de la cocción fue la separación de la cascarilla de la harina de lino en el agua remanente del proceso. Debido a estos motivos se descartó la incorporación de la harina de lino en el agua de cocción y se optó por mezclarla en la pasta ya cocida.

$\mathrm{Al}$ analizar el efecto del contenido de la harina de lino sobre las características de textura de las pastas se halló que a la máxima concentración $(5 \% \mathrm{p} / \mathrm{p})$ se dificultaba el laminado y moldeado de los snacks. Al aumentar la concentración de harina se estaría incorporando una mayor cantidad de fibra presente en la harina como mucílago, que generaría una mayor capacidad de retención de agua en la pasta. Marpalle y col. 
(2014) suplementaron masas de harina de trigo con harina de lino molida cruda y tostada obteniendo un aumento en la absorción de agua y en la adhesividad de la masa respecto de las muestras sin harina de lino. Este efecto fue atribuido a la disminución de la capacidad de retención de agua del gluten con el consecuente aumento de la pegajosidad.

Respecto al tiempo y temperatura de horneado de las pastas, se encontró que al agregar la harina de lino fue necesario aumentar el tiempo de horneado inicial en 5 min para poder obtener valores de humedad y $a_{w}$ que permitieran una mejor conservación del snack. Para la industria de alimentos debe existir un compromiso entre la energía a entregar durante el horneado del producto y el tiempo que demande dicho proceso, por lo cual se seleccionó un tiempo de 25 min y temperatura de $160^{\circ} \mathrm{C}$ para lograr un producto snack con características de humedad y actividad acuosa adecuadas.

\subsection{Efecto del agregado de harina de lino sobre las características fisicoquímicas y de textura de los snacks}

\subsubsection{Apariencia visual y color de los snacks}

La apariencia de un alimento influye en la aceptación por parte del consumidor aún antes de que éste sea introducido en la boca. Por ello, el moldeado en forma circular del snack, similar al de una papa frita, puede otorgarle un atractivo visual para inducir su consumo. En la Figura 3.4 se muestran fotografías de los snacks obtenidos con las diferentes concentraciones de harina de lino 1,3 y $5 \% p / p\left(L_{1}, L_{3}\right.$ y $L_{5}$, respectivamente) y el control $\left(\mathrm{M}_{0}\right)$. Se observa en todos los casos ensayados que la superficie del producto es rugosa y no uniforme, característica de este tipo de productos preparados a base de maíz. Sin embargo, el agregado de harina de lino incrementó aún más la no uniformidad del producto, debido a la granulometría propia de esta harina, además de impartirles una tonalidad más oscura.

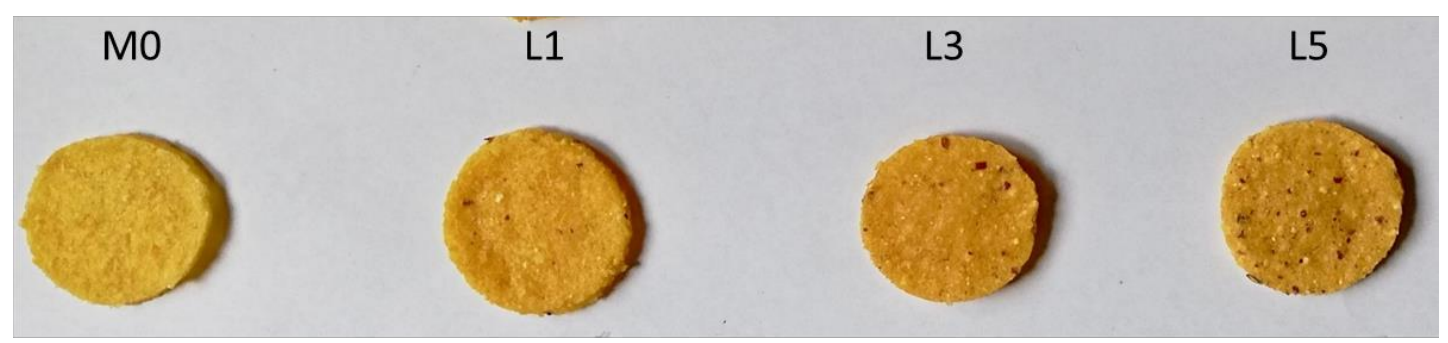

Figura 3.4. Apariencia de los snacks obtenidos a partir de maíz y harina de lino. Mo: control de maíz; $L_{1}, L_{3}$ y $L_{5}$ : con 1,3 y $5 \%$ p/p de harina de lino, respectivamente. 
La Tabla 3.1 muestra los parámetros de color superficial de los materiales utilizados en la elaboración junto a los valores determinados en el snack control y en el de menor concentración de harina de lino (1\% p/p), a fin de analizar el efecto de cada ingrediente sobre el color del producto final. Se observa que ambos snacks, control y con harina de lino, presentaron valores altos del parámetro $b^{*}$, debido principalmente al color amarillo del maíz, mientras que la luminosidad $L^{*}$ tomó un valor intermedio entre los correspondientes al maíz y a la harina de lino. Otros factores que influyeron en los parámetros $L^{*}, a^{*}$ y $b^{*}$ obtenidos en los snacks son el color marrón de la variedad de la semilla de lino usada para la obtención de la harina y la reacción de pardeamiento ocurrida durante el horneado del producto.

Tabla 3.1. Parámetros de color superficial de materias primas y productos snack.

\begin{tabular}{ccccc}
\hline Parámetro & Maíz & $\begin{array}{c}\text { Harina de } \\
\text { lino }\end{array}$ & $\begin{array}{c}\text { Snack } \\
\text { control }\left(M_{0}\right)\end{array}$ & $\begin{array}{c}\text { Snack con Harina } \\
\text { de lino }\left(L_{1}\right)\end{array}$ \\
\hline $\mathrm{a}^{*}$ & $5,58 \pm 1,02$ & $5,60 \pm 0,57$ & $8,49 \pm 0,25$ & $6,06 \pm 1,44$ \\
$\mathrm{~b}^{*}$ & $31,99 \pm 2,59$ & $13,52 \pm 0,32$ & $45,13 \pm 0,15$ & $42,12 \pm 3,27$ \\
$\mathrm{~L}^{*}$ & $74,38 \pm 2,28$ & $56,17 \pm 0,63$ & $64,74 \pm 1,11$ & $63,45 \pm 1,79$ \\
\hline
\end{tabular}

Al analizar el efecto de la concentración de harina de lino sobre el color de los snacks (Fig. 3.5) se observa que un mayor contenido condujo a la disminución de los parámetros $\mathrm{a}^{*}, \mathrm{~b}^{*}$ y $\mathrm{C}^{*}$, indicando un corrimiento de la zona de colores rojo y amarillo. Esta tendencia se correspondió también con el aspecto visual de los snacks (Fig. 3.4). Por otro lado, sólo a la máxima concentración de harina de lino $\left(L_{5}\right)$ se observa una disminución significativa $(p \leq 0,05)$ de la luminosidad $\left(L^{*}\right)$ denotando que estos snacks son más oscuros. Este mismo comportamiento fue hallado por otros autores al incrementar el contenido de harina de lino, en reemplazo de la harina de trigo, en sus formulaciones de galletas (Khouryieh y Aramouni, 2012) y de panes (Marpalle y col., 2014). No se observaron diferencias significativas $(p>0,05)$ en el parámetro $h^{*}$ de los snacks cuando se agregó harina de lino, por lo que se mantuvo en la zona de matices amarillos. 

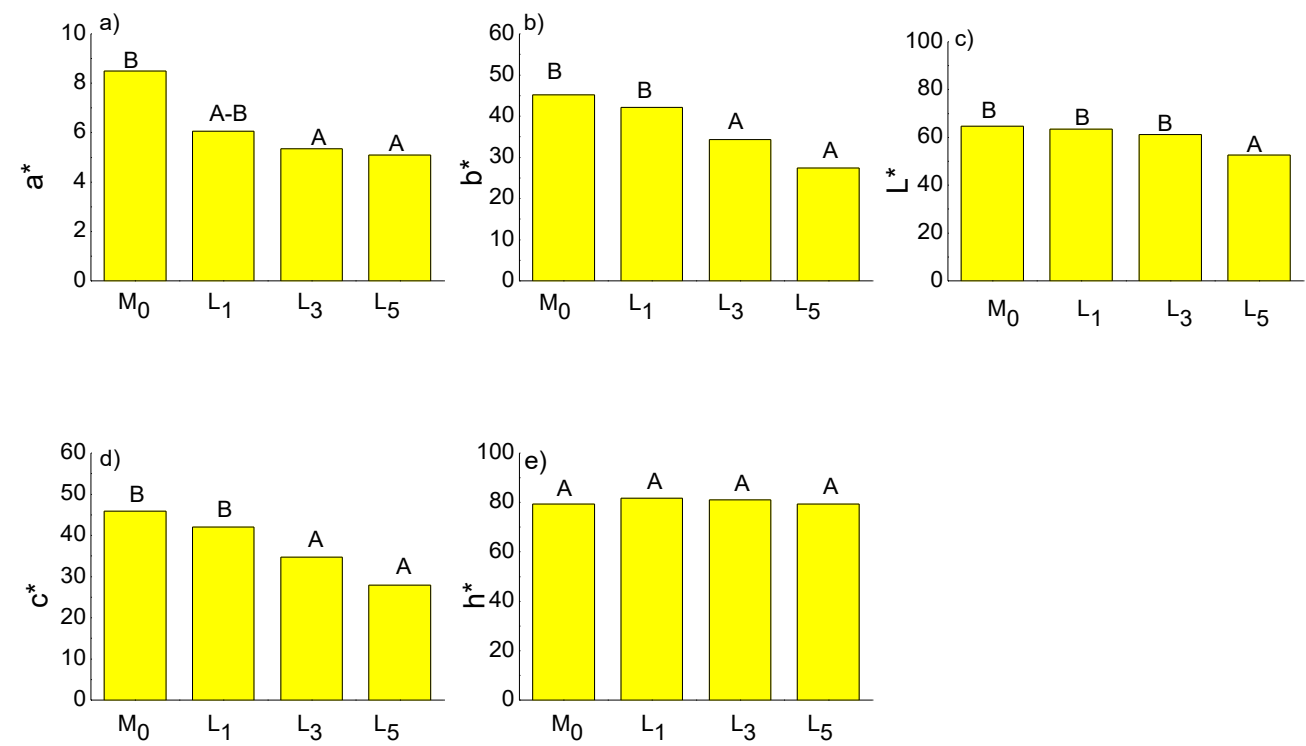

Figura 3.5. Parámetros de color de los snacks con diferentes concentraciones de harina de lino. Barras con una letra común en un mismo grafico no son significativamente diferentes $(p>0,05)$.

\subsubsection{Humedad y actividad acuosa $\left(a_{w}\right)$}

Los snacks son, en general, alimentos con bajo contenido de humedad y un aumento de este parámetro afecta directamente la textura del producto. En particular, la crocancia es el parámetro de textura que más se ve afectado con el aumento de la humedad siendo esto una causa de rechazo del producto. En la Figura 3.6a se observa que el contenido de agua de los snacks estuvo en el rango $4-10 \%$, obteniéndose el menor valor para las muestras control $\mathrm{M}_{0}$. Los valores de humedad hallados son típicos de productos tipo snack como barras de cereal o bocaditos (SunWaterhouse y col., 2010, Trevisan y Areas, 2012). El agregado de la harina de lino, cuyo contenido de humedad fue de $7,38 \pm 0,12 \%$, incrementó significativamente ( $p \leq$ $0,05)$ la humedad de las muestras, en orden creciente según la concentración de la harina. Este mismo comportamiento fue hallado en estudios realizados en panificados con harina de trigo y adición parcial de harina de lino a la formulación (Figuerola y col., 2008). Garda y col. (2012) encontraron resultados similares en panes formulados sin harina de trigo y con adición de semillas de lino y chía. 

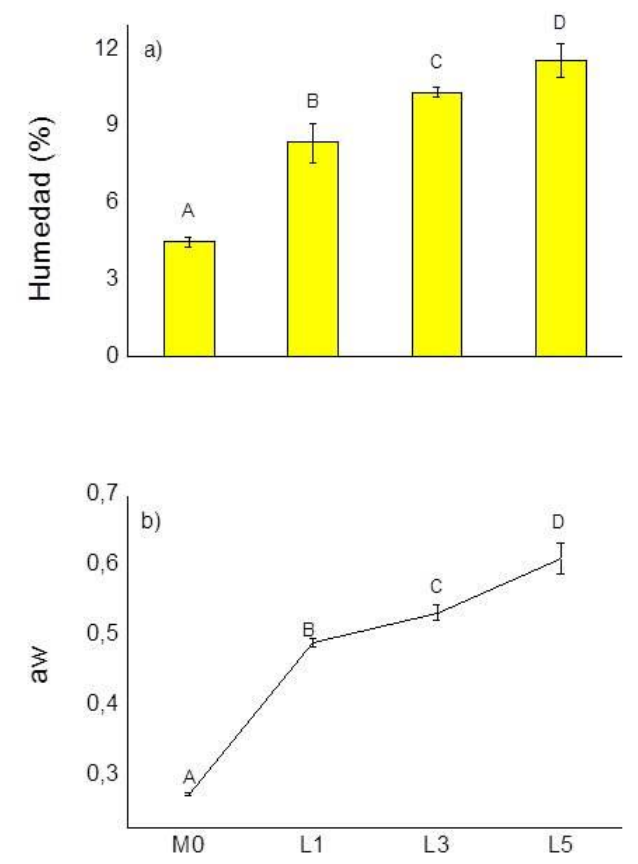

Figura 3.6. Efecto del agregado de harina de lino sobre a) contenido de humedad y b) actividad acuosa (aw) de snacks a base de maíz

En la figura "a" barras con una letra común no son significativamente diferentes $(p>0,05)$. En la figura "b" Valores en cada punto con una letra mayúsculas en común no son significativamente diferentes ( $p>$ $0,05)$.

Respecto a la actividad acuosa de los snacks (Fig. 3.6b), se observó una tendencia similar a la hallada para la humedad. Se hallaron diferencias significativas entre todos los valores de $a_{w}$ de las muestras con diferente concentración de harina de lino. El mayor contenido de fibra de la muestra $L_{5}$ sería responsable del valor elevado de $a_{w}$ hallado $(0,609)$. De acuerdo con Labuza (1980), los alimentos con $a_{w}$ mayor a 0,6 presentan un mayor riesgo microbiológico. Por lo tanto, para elaborar los snacks con extracto de yerba mate se decidió continuar con la formulación $L_{3}$ que presentó valores de humedad y $a_{w}$ adecuados para la mejor conservación de los snacks.

\subsubsection{Propiedades de textura de los snacks}

Como ya se mencionó, las características de textura de los snacks dependen de la humedad y actividad acuosa resultantes en el producto luego del horneado, como así también de los ingredientes y su concentración. En la Figura 3.7 se presentan los perfiles de textura obtenidos en el texturómetro y en la Tabla 3.2 los parámetros calculados a partir de dichas curvas: estrés de fractura, módulo elástico y tensión de deformación en la fractura para los snacks con 1, 3 y 5\% p/p de harina de lino. 


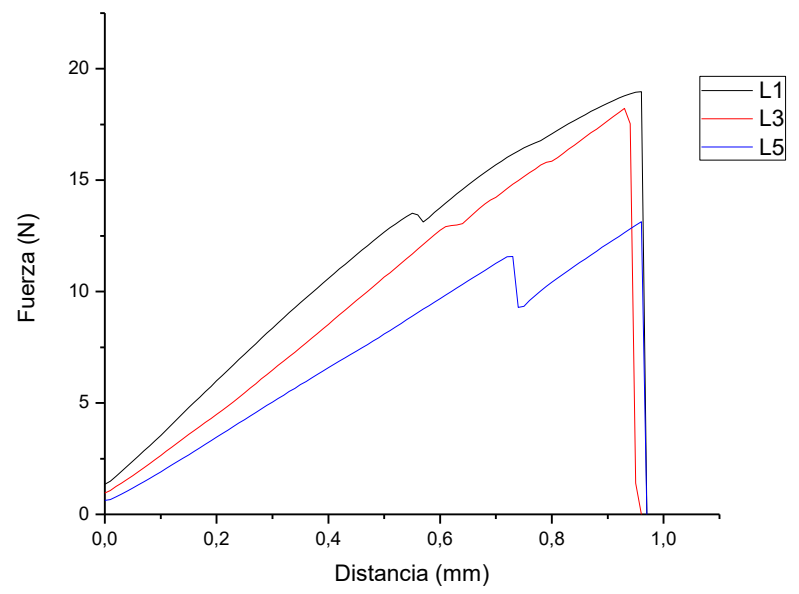

Figura 3.7. Perfiles de textura de los snacks con harina de lino al $1 \%\left(L_{1}\right), 3 \%\left(L_{3}\right)$ y $5 \%\left(L_{5}\right)$.

Tabla 3.2. Estrés de fractura $\sigma$, módulo elástico $E$ y tensión de fractura $\varepsilon$ de los snacks control (Mo) y con harina de lino al $1 \%\left(L_{1}\right), 3 \%\left(L_{3}\right)$ y $5 \%\left(L_{5}\right)$.

\begin{tabular}{ccccc}
\hline Parámetro & $\mathrm{M}_{0}$ & $\mathrm{~L}_{1}$ & $\mathrm{~L}_{3}$ & $\mathrm{~L}_{5}$ \\
\hline$\sigma(\mathrm{MPa})$ & $6,48 \pm 0,01^{\mathrm{b}}$ & $6,22 \pm 0,35^{\mathrm{b}}$ & $4,93 \pm 0,78^{\mathrm{ab}}$ & $4,57 \pm 0,90^{\mathrm{a}}$ \\
$E(\mathrm{MPa})$ & $328,43 \pm 23,52^{\mathrm{ab}}$ & $292,25 \pm 22,99^{\mathrm{b}}$ & $280,47 \pm 31,36^{\mathrm{ab}}$ & $224,63 \pm 19,88^{\mathrm{a}}$ \\
$\varepsilon \times 10^{3}$ (adim) & $15,8 \pm 3,8^{\mathrm{a}}$ & $19,9 \pm 2,4^{\mathrm{ab}}$ & $22,4 \pm 2,2^{\mathrm{ab}}$ & $22,8 \pm 3,2^{\mathrm{b}}$ \\
\hline
\end{tabular}

El estrés de fractura se relaciona con la dureza de un material y consiste en la separación en dos o más piezas bajo la acción de una tensión aplicada. En el caso de un producto como los snacks, este parámetro cobra relevancia ya que es la primera característica sensorial que apreciará el consumidor al probarlo. En la Tabla 3.2 se observa que el agregado de la harina de lino disminuye el estrés de fractura de las muestras y este efecto es más pronunciado al aumentar su concentración en la formulación. La harina de lino hace menos rígida la estructura al retener más agua en ella por su contenido en fibra. Similares resultados hallaron Sun-Waterhouse y col. (2010) al agregar inulina a barras de cereal, obteniendo barras con menor dureza.

La disponibilidad de agua presente en la matriz del alimento determinará parámetros de textura importantes en la aceptabilidad de un producto como la crocancia, la cual se asocia con contrastes texturales agradables y con la frescura y calidad del producto, siendo su pérdida la principal causa del rechazo por parte de los consumidores (Roudaut y col., 1998; Marzec y col., 2006). La crocancia de los cereales ha sido relacionada con su contenido de agua o su actividad acuosa por 
Martínez y col. (2004) y Heidenreich y col. (2004). En el caso del snack de maíz, su bajo contenido de humedad $(4 \%)$ y de $a_{w}(0,27)$ condujeron a un producto que, si bien es apto desde el punto de vista microbiológico, presentó alta dureza al consumirlo. Por ello, el agregado de harina de lino resultó en características favorables al disminuir su dureza sin alterar la crocancia.

En la Tabla 3.2 también se muestra la variación del módulo de elasticidad o de Young (E) de los snacks sin y con diferentes concentraciones de lino. Esta propiedad relaciona la deformación elástica con la tensión, cuanto menor es el $\mathrm{E}$, mayor será la deformación del material y cuanto mayor, más rígida es la muestra. En concordancia con el estrés de fractura, la incorporación de harina de lino en los snacks de maíz condujo a menores valores del módulo elástico. Este comportamiento resultó una característica favorable para los snacks formulados con lino ya que facilitó la mordida al ser más deformable. Esto podría explicarse considerando que las muestras con mayor cantidad de harina de lino $\left(L_{3}\right.$ y $\left.L_{5}\right)$ aportarían una cantidad extra de proteínas por sobre las que ya tiene la muestra control $\left(\mathrm{M}_{0}\right)$, además de una mayor retención de agua por parte de sus mucilagos que plastificaría las muestras.

Por su parte, la tensión de fractura $\varepsilon$ es una característica que se correlaciona con la friabilidad, es decir con la capacidad de un producto para ser reducido a partículas pequeñas por la acción de una mínima presión o fricción, a menor tensión de fractura más friable es el producto. Se puede observar en la Tabla 3.2 que este parámetro no presentó diferencias significativas con el agregado de la harina de lino comparado con la muestra control $\left(M_{0}\right)$ ni entre las diferentes concentraciones de harina de lino ensayadas.

Según los resultados obtenidos, si bien los snacks con harina de lino al $5 \%$ presentaron buena textura, mostraron características menos favorables desde el punto de vista del procesamiento de la pasta por su adhesividad y dificultad para su laminado (sección 3.1), como así también desde su conservación debido al alto contenido de humedad y actividad acuosa de los snacks. Por lo tanto, se decidió continuar con la formulación con $3 \%$ de harina de lino para incorporar el extracto de yerba mate a los snacks de maíz. 


\subsection{Efecto del agregado de extracto de yerba mate sobre las propiedades}

fisicoquímicas y de textura de los snacks con harina de lino

\subsubsection{Apariencia visual y color de los snacks con yerba mate}

En la Figura 3.8 se muestran fotografías de los snacks con harina de lino al $3 \%$ $\mathrm{p} / \mathrm{p}$ y extracto de yerba mate al 1 y al $3 \% \mathrm{p} / \mathrm{p}$, comparados con su control sin yerba. Se observa que el agregado de extracto hizo que los snacks $\left(L_{3} Y_{1}\right.$ y $\left.L_{3} Y_{3}\right)$ adquirieran una tonalidad más intensa y se volvieran más oscuros que el control $L_{3}$. Respecto a la concentración de extracto agregado, a simple vista no se distingue la diferencia de color entre las dos concentraciones de yerba mate (1\% y $3 \%)$.

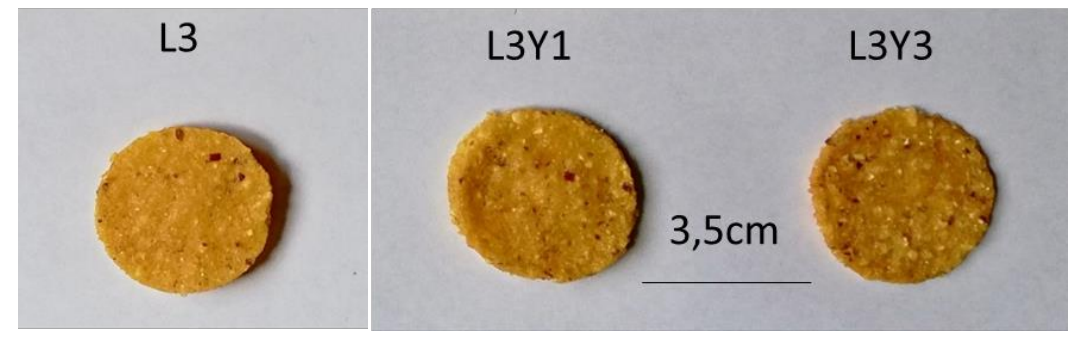

Figura 3.8. Apariencia de los snacks obtenidos a partir de maíz, harina de lino al $3 \%$ y extracto de yerba mate. $L_{3}$ : control sin extracto, $L_{3} Y_{1}$ y $L_{3} Y_{3}$ : con $1 \%$ y $3 \%$ de extracto, respectivamente.

Al determinar el color superficial de las muestras, se observó que el agregado de extracto de yerba mate disminuyó significativamente $(p \leq 0,05)$ el parámetro $b^{*}$ y la luminosidad $L^{*}$ (para la muestra con mayor concentración de yerba), mientras que $a^{*}$ no varió significativamente, respecto al control sin harina de lino (Fig. 3.9).
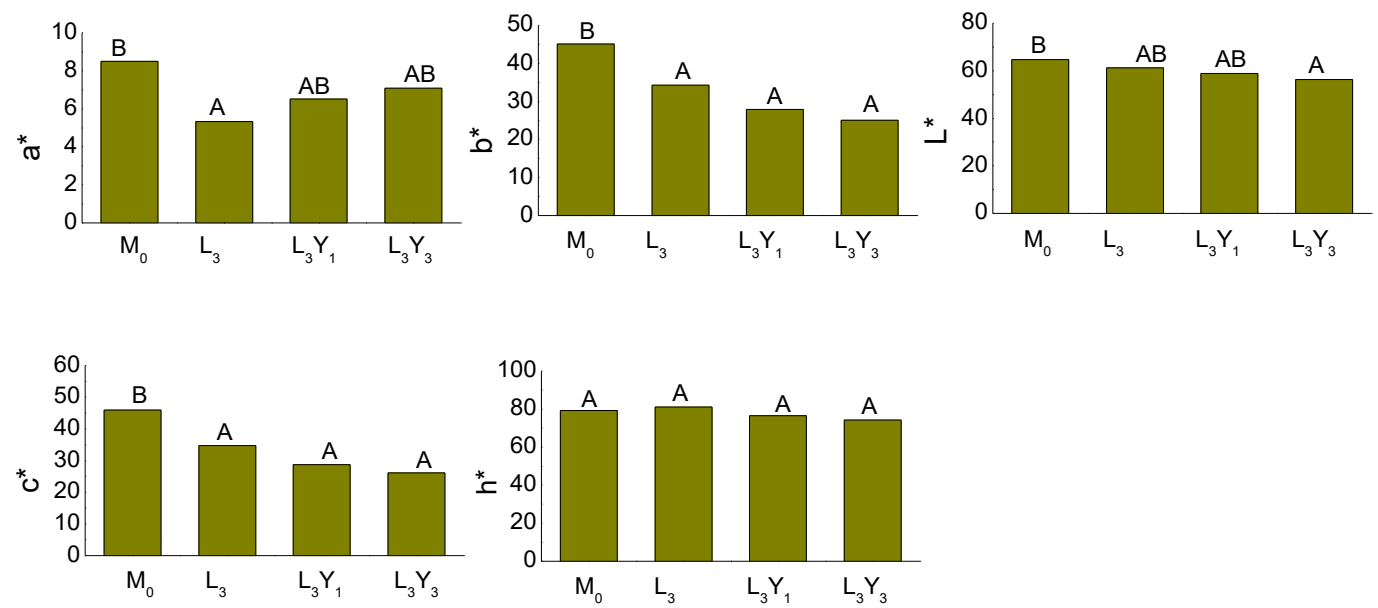

Figura 3.9. Parámetros de color de snacks con $3 \% \mathrm{p} / \mathrm{p}$ de harina de lino y $1 \%$ y $3 \% \mathrm{p} / \mathrm{p}$ de extracto de yerba mate.

Barras con una letra común en un mismo gráfico no son significativamente diferentes $(p>0,05)$. 
El efecto del extracto de yerba mate sobre el color de los snacks puede deberse principalmente al propio color del extracto $\left(L^{*} 55,68 \pm 1,12\right.$, $b^{*} 15,96 \pm 1,42$ y $a *$ $0,26 \pm 0,18)$. El color de snacks con agregado de extractos vegetales puede estar influenciado por reacciones de pardeamiento no enzimático de los polifenoles, incluyendo la oxidación de polifenoles no enzimática y el pardeamiento polifenólico autooxidativo (Sun-Waterhouse y col., 2010).

Por otro lado, no se observaron diferencias significativas $(p>0,05)$ en los parámetros $L^{*}, a^{*} y b^{*}$ a las dos concentraciones de yerba mate ensayadas respecto al control $L_{3}$. Por su parte, el parámetro $h^{*}$ no presentó diferencias significativas en las distintas muestras, lo cual es favorable ya que en los snacks con yerba mate se conservó el matiz amarillo de los snacks con sólo maíz como ingrediente.

\subsubsection{Humedad y actividad acuosa}

En los snacks con agregado de extracto de yerba mate se observó una disminución significativa ( $p \leq 0,05)$ en el contenido de humedad respecto al control, como lo muestra la Tabla 3.3. Por otro lado, no se encontraron diferencias significativas $(p>0,05)$ en los valores de humedad a los dos niveles de concentración de extracto ensayados. En cambio, el efecto de la yerba mate sobre la actividad acuosa de los snacks varió según la concentración del extracto agregado (Tabla 3.3). Al comparar con el control, no se observaron diferencias significativas en la $a_{w}$ de los snacks con $1 \%$ de extracto $\left(L_{3} Y_{1}\right)$, sin embargo, un mayor contenido de extracto condujo a una disminución significativa $(p \leq 0,05)$ de $a_{w}$ en los snacks.

Tabla 3.3. Efecto del agregado de extracto de yerba mate sobre el contenido de humedad y la actividad acuosa $\left(a_{w}\right)$ de los snacks a base de maíz y harina de lino.

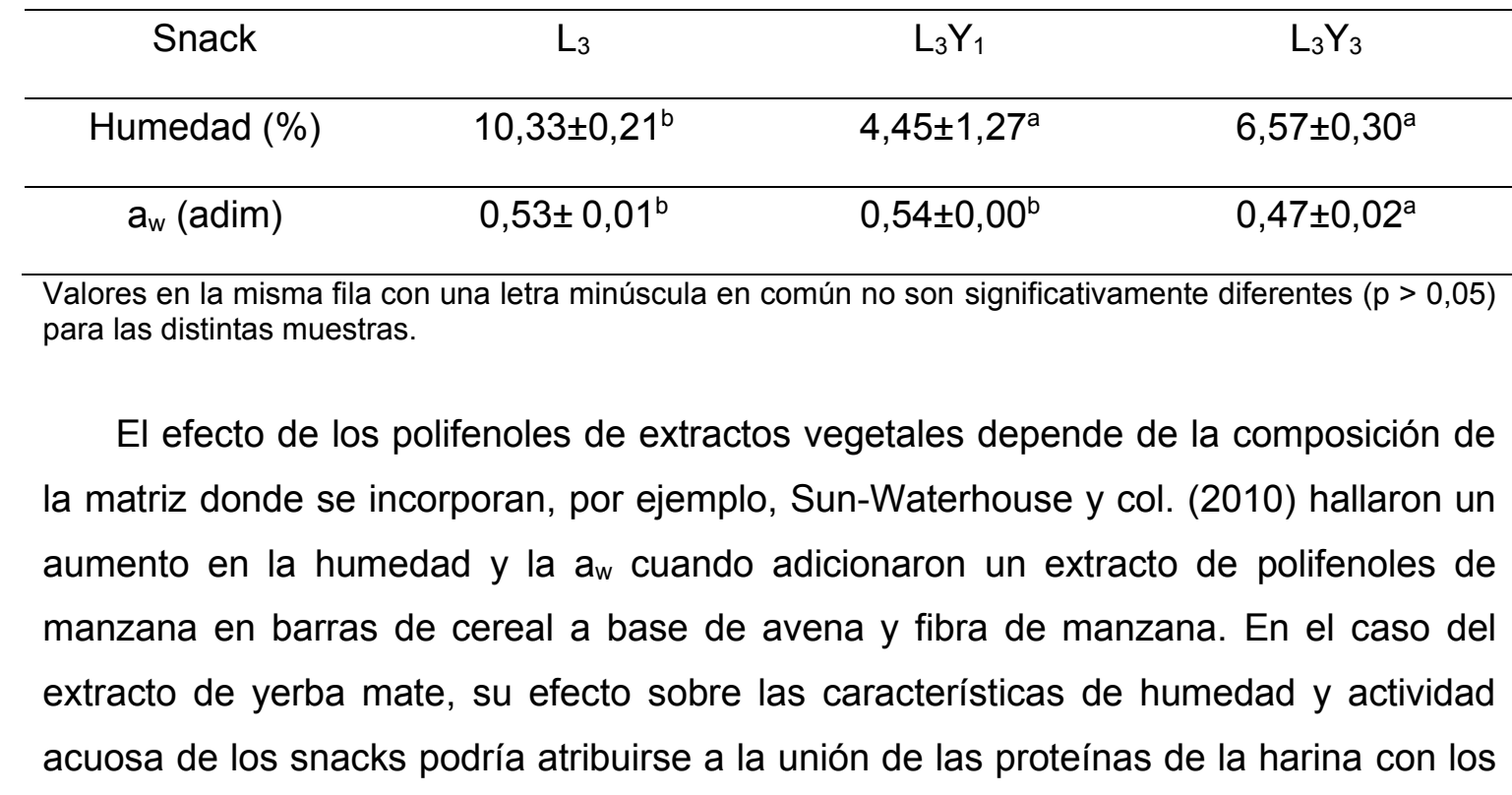


flavonoides de la yerba mate que produce la reducción del número de grupos hidroxilo libres (Arts y col., 2001, 2002), disminuyendo así la capacidad de captar agua.

\subsubsection{Propiedades de textura}

La Figura 3.10 muestra los perfiles de textura de los snacks a base de maíz, harina y extracto de yerba mate y la Tabla 3.4 presenta los parámetros correspondientes de estrés de fractura, módulo elástico y tensión de fractura obtenidos a partir de dichos perfiles.

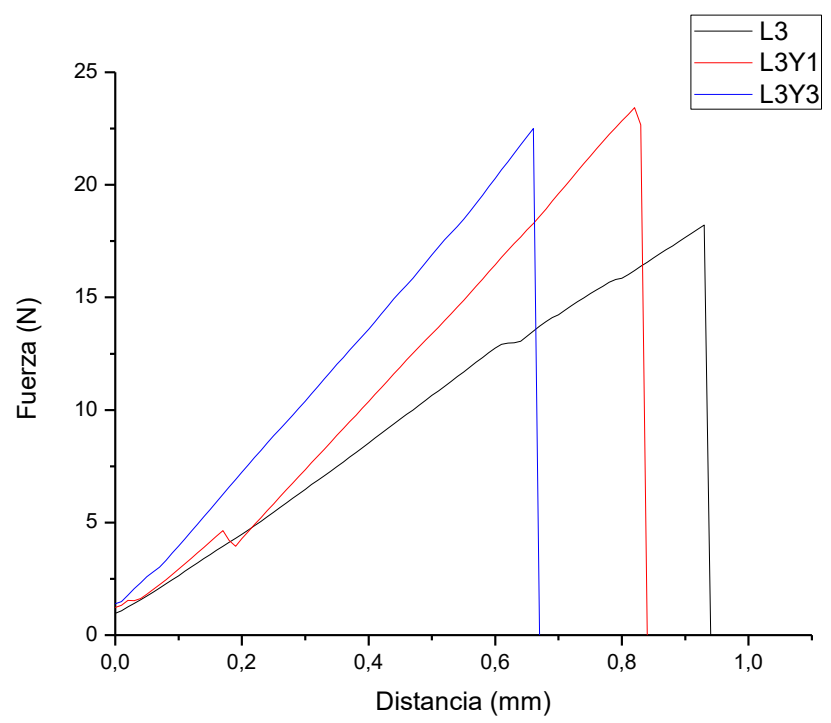

Figura 3.10. Perfiles de textura de los snacks con harina de lino al $3 \%\left(\mathrm{~L}_{3}\right)$ y $1 \%\left(\mathrm{~L}_{3} \mathrm{Y}_{1}\right)$ y $3 \%$ $\left(\mathrm{L}_{3} \mathrm{Y}_{3}\right)$ de extracto de yerba mate.

Tabla 3.4. Estrés de fractura $\sigma$, módulo elástico $E$ y tensión de fractura $\varepsilon$ de los snacks con harina de lino al $3 \%\left(L_{3}\right)$ y $1 \%\left(L_{3} Y_{1}\right)$ y $3 \%\left(L_{3} Y_{3}\right)$ de extracto de yerba mate.

\begin{tabular}{cccc}
\hline Parámetro & $\mathrm{L}_{3}$ & $\mathrm{~L}_{3} \mathrm{Y}_{1}$ & $\mathrm{~L}_{3} \mathrm{Y}_{3}$ \\
\hline$\sigma(\mathrm{MPa})$ & $4,93 \pm 0,78^{\mathrm{a}}$ & $5,47 \pm 0,96^{\mathrm{a}}$ & $5,01 \pm 0,39^{\mathrm{a}}$ \\
$E(\mathrm{MPa})$ & $280,47 \pm 21,36^{\mathrm{a}}$ & $332,76 \pm 16,20^{\mathrm{b}}$ & $342,00 \pm 11,50^{\mathrm{b}}$ \\
$\varepsilon \times 10^{3}$ (adim) & $22,4 \pm 2,2^{\mathrm{b}}$ & $16,6 \pm 0,5^{\mathrm{a}}$ & $14,4 \pm 2,5^{\mathrm{a}}$ \\
\hline
\end{tabular}

Respecto al estrés de fractura se halló que no existen diferencias significativas ( $p$ $>0,05)$ en los valores de este parámetro para los snacks sin y con 1 y $3 \%$ de extracto de yerba mate. Sin embargo, el módulo elástico aumentó y la tensión de fractura de los snacks con extracto de yerba mate disminuyó significativamente $(p<0,05)$ comparados con el control sin extracto. Estos comportamientos indicarían que la yerba 
mate vuelve más rígida la estructura de los snacks con harina de lino y contribuye a su friabilidad. Las modificaciones en la textura de los snacks podrían atribuirse a la formación de complejos entre los compuestos antioxidantes de la yerba (polifenoles y flavonoides) y los componentes de la matriz (almidón y proteínas) (Arts y col., 2001, 2002, Wu y col., 2016).

\subsection{Almacenamiento de los snacks con harina de lino y extracto de yerba mate}

\subsubsection{Variación de la actividad acuosa}

La evaluación de los parámetros de textura y de actividad acuosa de los snacks durante el almacenamiento es importante para determinar su seguridad microbiológica y la conservación de sus características sensoriales. En la Tabla 3.5 se observa que durante los 30 días de ensayo todas las muestras, sin y con harina de lino y/o extracto de yerba mate, presentaron valores de $a_{w}$ entre 0,27 y 0,59 , todos ellos aceptables desde el punto de vista microbiológico del alimento. La mayor variación se observó en la muestra control $\mathrm{M}_{0}$ que aumentó significativamente su actividad acuosa en los primeros 7 días. En cambio, el agregado de harina de lino condujo a fluctuaciones menores en la $a_{w}$ de los snacks hasta los 14 días de almacenamiento, denotando un efecto de mayor estabilidad sobre las muestras almacenadas. Sin embargo, en el día 21 de ensayo todas las muestras sin y con harina de lino presentaron una disminución significativa de $a_{w}$, para luego aumentar al final del almacenamiento. Aun así, no se alcanzaron los valores medidos al tiempo 0 excepto por la muestra $L_{1}$ que presentó un valor mayor, pero sin diferencias significativas $(p>0,05)$.

Tabla 3.5. Actividad acuosa $\left(a_{w}\right)$ en función del tiempo de almacenamiento y de la composición de los snacks sin y con harina de lino y extracto de yerba mate.

\begin{tabular}{ccccccc}
\hline $\begin{array}{c}\text { Tiempo } \\
\text { (días) }\end{array}$ & $\mathrm{M}_{0}$ & $\mathrm{~L}_{1}$ & $\mathrm{~L}_{3}$ & $\mathrm{~L}_{5}$ & $\mathrm{~L}_{3} \mathrm{Y}_{1}$ & $\mathrm{~L}_{3} \mathrm{Y}_{3}$ \\
\hline 0 & $0,272 \pm 0,002^{\mathrm{Aa}}$ & $0,489 \pm 0,002^{\mathrm{Bb}}$ & $0,531 \pm 0,011^{\mathrm{Cc}}$ & $0,609 \pm 0,022^{\mathrm{Dd}}$ & $0,541 \pm 0,004^{\mathrm{Cc}}$ & $0,468 \pm 0,016^{\mathrm{Bb}}$ \\
7 & $0,526 \pm 0,015^{\mathrm{Db}}$ & $0,496 \pm 0,004^{\mathrm{Ba}}$ & $0,592 \pm 0,001^{\mathrm{Dd}}$ & $0,547 \pm 0,004^{\mathrm{Cc}}$ & $0,510 \pm 0,003^{\mathrm{Ba}}$ & $0,574 \pm 0,013^{\mathrm{Dd}}$ \\
14 & $0,525 \pm 0,025^{\mathrm{Db}}$ & $0,539 \pm 0,006^{\mathrm{Cb}}$ & $0,522 \pm 0,028^{\mathrm{Cb}}$ & $0,558 \pm 0,001^{\mathrm{Cb}}$ & $0,436 \pm 0,008^{\mathrm{Aa}}$ & $0,399 \pm 0,002^{\mathrm{Aa}}$ \\
21 & $0,328 \pm 0,026^{\mathrm{Ba}}$ & $0,411 \pm 0,009^{\mathrm{Ac}}$ & $0,361 \pm 0,001^{\mathrm{Ab}}$ & $0,442 \pm 0,000^{\mathrm{Ad}}$ & $0,497 \pm 0,004^{\mathrm{Be}}$ & $0,480 \pm 0,009^{\mathrm{Be}}$ \\
30 & $0,411 \pm 0,002^{\mathrm{Ca}}$ & $0,508 \pm 0,011^{\mathrm{Bc}}$ & $0,423 \pm 0,001^{\mathrm{Ba}}$ & $0,508 \pm 0,007^{\mathrm{Bc}}$ & $0,443 \pm 0,006^{\mathrm{Ab}}$ & $0,518 \pm 0,001^{\mathrm{Cc}}$
\end{tabular}

Valores en la misma columna con letra mayúscula en común no son significativamente diferentes ( $p>$ $0,05)$ para los distintos tiempos. Valores en la misma fila con una letra minúscula en común no son significativamente diferentes $(p>0,05)$ para las distintas formulaciones. 
En el caso de las muestras con yerba, el agregado de $3 \%$ del extracto $\left(L_{3} Y_{3}\right)$ condujo a mayores variaciones de $a_{w}$ durante los 30 días de ensayo, comparado con las muestras con $1 \%\left(L_{3} Y_{1}\right)$ donde se observaron las menores fluctuaciones durante todo el período de almacenamiento ensayado (Tabla 3.5).

La variación de la actividad acuosa de los snacks durante el almacenamiento puede relacionarse a la liberación de agua debida al proceso de retrogradación del almidón. Este proceso involucra el reordenamiento de las cadenas de amilosa y amilopectina que quedaron retenidas en el interior del gránulo luego del proceso de gelatinización ocurrido durante el calentamiento del maíz. Durante la retrogradación, las cadenas lineales de amilosa y las ramificaciones de la estructura de la amilopectina se alinean expulsando el agua retenida en las cadenas, la cual está disponible para migrar en la matriz del alimento. Esta modificación en la estructura cristalina del almidón otorga mayor rigidez a los gránulos lo cual se traduce en cambios en la textura del alimento.

\subsubsection{Modificaciones en la textura de los snacks con harina de lino}

Respecto al comportamiento de textura durante el almacenamiento de los snacks con harina de lino, sin yerba mate, en la Figura 3.11 se muestra la variación de los parámetros de estrés de fractura, módulo elástico y tensión de fractura a cada tiempo ensayado. Se observa que el estrés de fractura para todas las formulaciones, excepto $L_{3}$, disminuyó con el tiempo, para luego recuperar valores comparables con el tiempo 0 en los últimos días del almacenamiento (Fig. 3.11a). Al realizar el análisis para las distintas formulaciones a un tiempo dado, se observa que, en líneas generales, el agregado de harina de lino disminuye el estrés de fractura en las formulaciones con mayor concentración (3\% y 5\%). La harina de lino haría menos rígida la estructura en los primeros 14 días, al retener más agua debido a su contenido de fibra. Durante este tiempo, para cada una de las formulaciones, se observó una disminución del estrés de fractura, a excepción de $L_{3}$ la cual aumentó durante este tiempo, retomando los valores iniciales para el fin del almacenamiento. Por otro lado, la estructura heterogénea y compleja del grano de maíz sufre modificaciones en el almacenamiento que conducirían a una mayor variación en los parámetros de textura. 


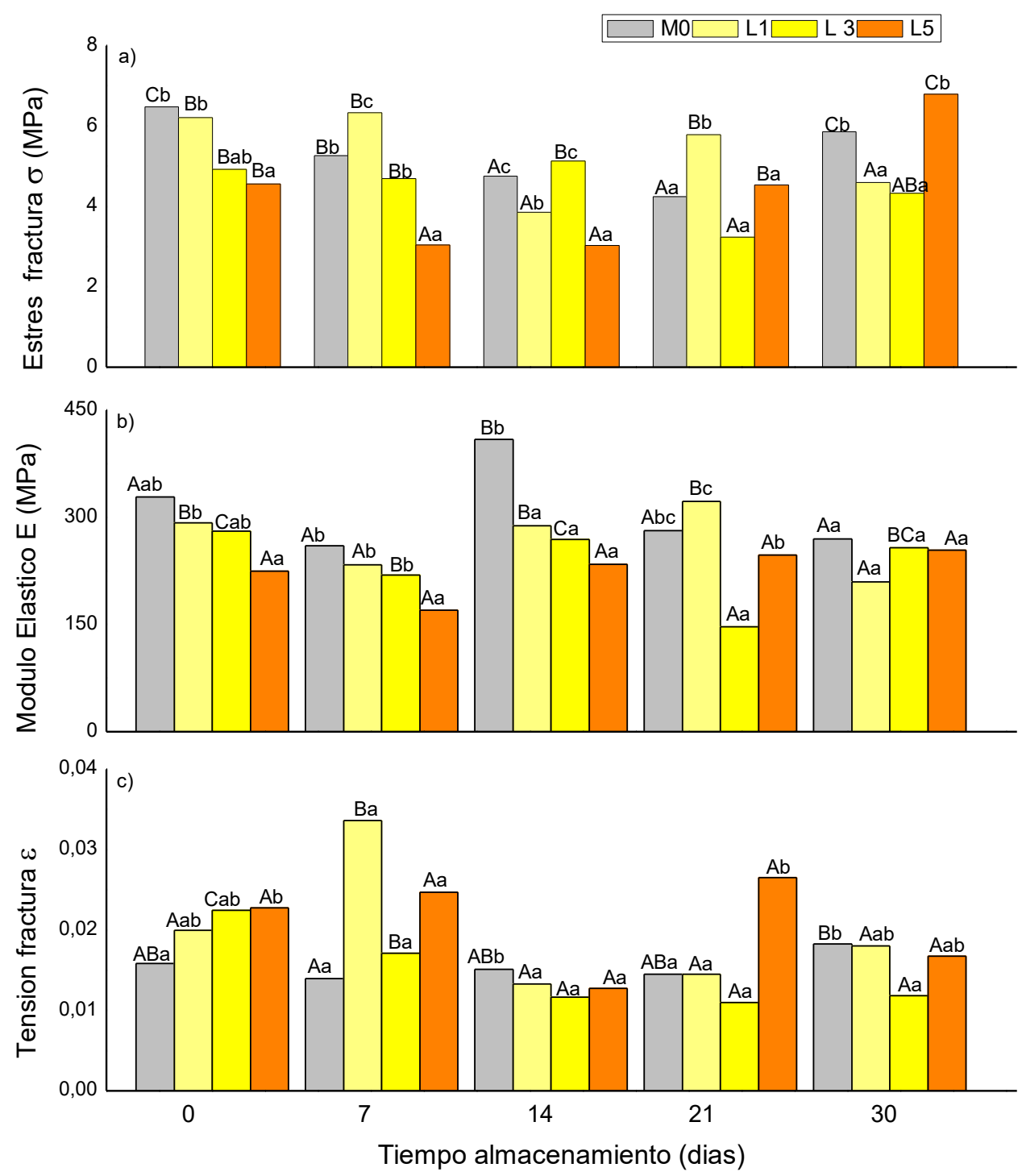

Figura 3.11. Estrés de fractura (a), módulo elástico (b) y tensión de fractura (c) de los snacks, sin y con harina de lino, en función del tiempo de almacenamiento a $20^{\circ} \mathrm{C}$.

Valores con letra mayúscula en común no son significativamente diferentes $(p>0,05)$ para los distintos tiempos. Valores con letra minúscula en común no son significativamente diferentes $(p>0,05)$ para las distintas formulaciones.

Con respecto a la variación del módulo elástico (E) de los snacks durante el almacenamiento (Fig. 3.11b), se observó una tendencia general de disminución de este parámetro en todas las muestras ensayadas hasta el día 7. Cuando se analizan las diferentes formulaciones a los distintos tiempos de almacenamiento se observa una leve tendencia a disminuir con el incremento de la concentración de harina de lino, excepto en el día 30. Esto indicaría que las muestras con mayor contenido de harina de lino son más deformables en los primeros días del almacenamiento.

Usualmente, en alimentos, el endurecimiento es un fenómeno multifactorial que depende de la composición, de los cambios fisicoquímicos de los componentes y sus interacciones y de las condiciones de almacenamiento. Este fenómeno puede ser explicado considerando que durante el almacenamiento hay una migración del agua 
debido al proceso de retrogradación, propio de sistemas que contienen almidón. El agua sería retenida en la matriz del alimento por la harina de lino que ya desde un inicio absorbió más agua que el tratamiento que no la contiene, lo cual se evidencia en los valores más bajos de $\mathrm{E}$ para las mayores concentraciones de la harina de lino (Fig.3.11b).

Respecto a la tensión de fractura $(\varepsilon)$ de los snacks, en la Figura 3.11c se observa que la muestra $M_{0}$ no presentó diferencias significativas $(p>0,05)$ en este parámetro durante todo el almacenamiento, excepto en el día 7 que mostró un leve descenso. Por el contrario, las muestras con harina de lino (excepto $L_{3}$ que disminuyó en el tiempo) aumentaron la tensión de fractura hasta el día 7 y luego disminuyeron alcanzando valores similares o incluso menores que al tiempo 0 . En cuanto al análisis entre tratamientos al mismo tiempo (Fig. 3.11c) se encontró que hasta el día 7 la tensión de fractura de las muestras conteniendo harina de lino aumentó respecto de la muestra control $\left(\mathrm{M}_{0}\right)$. Esto sugeriría que luego de una semana de almacenamiento el producto se vuelve menos friable con una mayor cohesividad estructural. En cambio, el día 14 las muestras con harina de lino disminuyeron la tensión de fractura respecto del control. Posteriormente, desde el día 21 y hasta el final del almacenamiento las muestras con harina de lino mostraron valores similares a $M_{0}$, excepto $L_{5}$ el día 21 y $L_{3}$ el día 30 que mostraron valores significativamente más altos y más bajos, respectivamente.

\subsubsection{Comportamiento de textura de los snacks con harina de lino y yerba mate}

En la Figura 3.12 se observa el efecto del extracto de yerba mate sobre los parámetros de textura de los snacks almacenados. Las muestras que contienen el extracto siguieron un comportamiento similar al mencionado anteriormente para el estrés de fractura, excepto que al día 30 de almacenamiento no se recuperaron los valores iniciales (Fig. 3.12a). Wu y col. (2009) hallaron fuerte evidencia de que los polifenoles del té disminuirían el proceso de retrogradación del almidón de arroz debido a que los radicales hidroxilos altamente reactivos de los polifenoles podrían reaccionar con el almidón para formar enlaces de hidrógeno, previniendo así la reasociación de cadenas de amilosa y amilopectina. En el caso de los snacks, en los primeros días prevalecería el fenómeno de retrogradación que vuelve a las muestras más duras y al final del almacenamiento este fenómeno se vería atenuado por los polifenoles de la yerba mate que reaccionarían en forma similar a los del té. Por lo tanto, se podría decir que existiría una competencia entre esos dos procesos que definen la textura de los snacks durante el almacenamiento. 


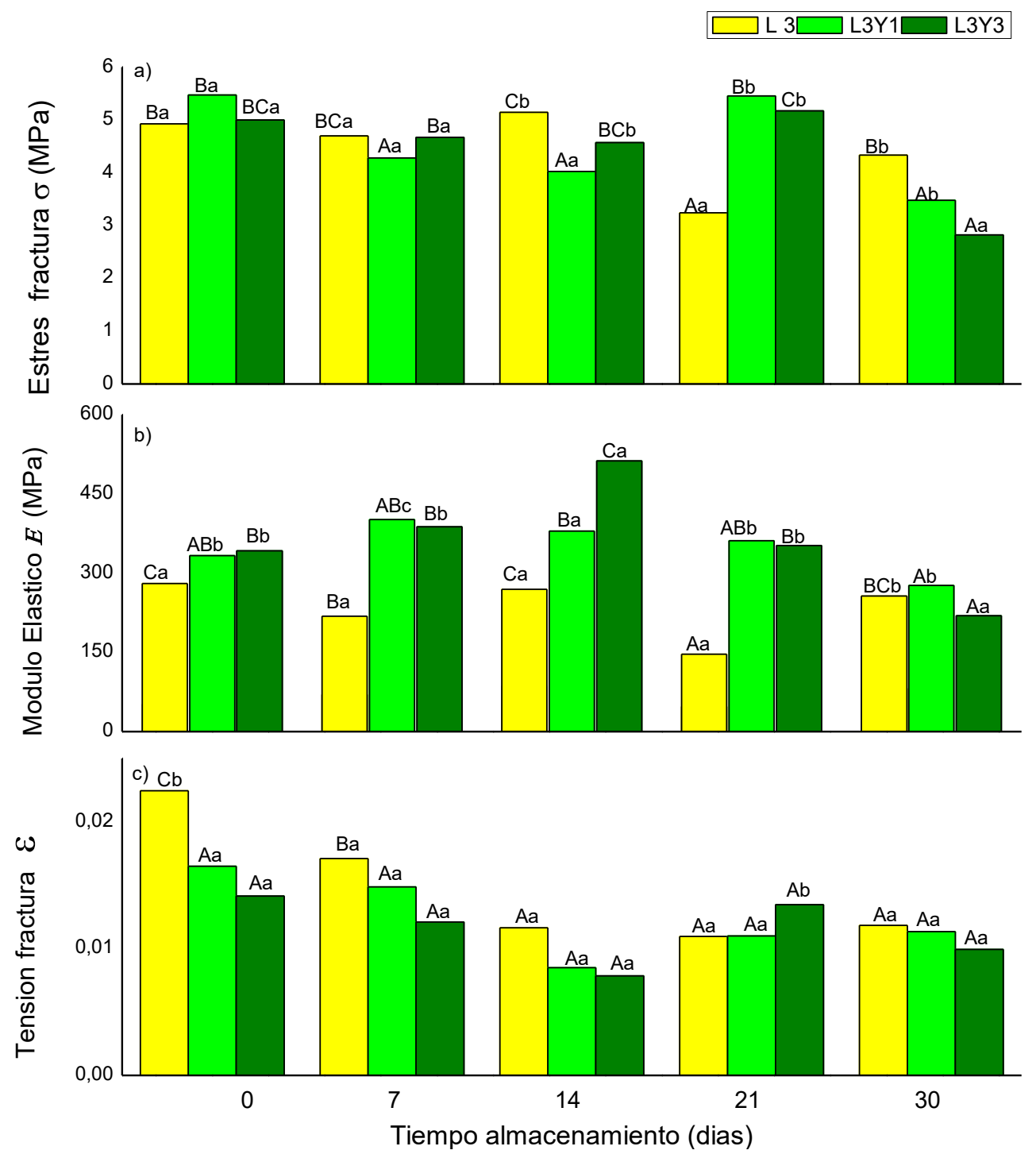

Figura 3.12. Estrés de fractura (a), módulo elástico (b) y tensión de fractura (c) de los snacks con $3 \%$ de harina de lino $\left(L_{3}\right)$ y $1 \%\left(L_{3} Y_{1}\right)$ y $3 \%\left(L_{3} Y_{3}\right)$ de extracto de yerba mate, en función del tiempo de almacenamiento.

Valores con letra mayúscula en común no son significativamente diferentes $(p>0,05)$ para los distintos tiempos. Valores con letra minúscula en común no son significativamente diferentes $(p>0,05)$ para las distintas formulaciones.

Cuando se compara a igual tiempo las distintas concentraciones de extracto de yerba mate (Fig. 3.12a) se encontró que no existen diferencias significativas $(p>0,05)$ hasta el día 7 del almacenamiento, luego el día 21 los valores de estrés de fractura fueron significativamente mayores $(p \leq 0,05)$ en las muestras conteniendo yerba mate. Esto indicaría una mayor estabilidad en estas muestras respecto al control sin yerba. Por el contrario, al día 30 las muestras con yerba mate mostraron valores de estrés de fractura significativamente menores $(p \leq 0,05)$.

En la Figura $3.12 \mathrm{~b}$ se observa que las muestras con extracto de yerba mate incrementaron su módulo elástico con un máximo alrededor del día 14 del almacenamiento, para luego disminuir hasta alcanzar valores similares a los del inicio. 
En cuanto al análisis entre tratamientos al mismo tiempo (Fig. 3.12b) se encontró que el extracto de yerba mate, en todas las concentraciones ensayadas, aumentó significativamente $(p \leq 0,05)$ el $E$ hasta el día 21 del almacenamiento. Luego al día 30 no hubo diferencias significativas $(p \geq 0,05)$ entre $L_{3}$ y $L_{3} Y_{1}$ pero sí disminuyó significativamente $(p \leq 0,05)$ el $E$ de la muestra $L_{3} Y_{3}$.

El agregado de extracto de yerba mate a ambas concentraciones disminuye, en el tiempo, la tensión de fractura de las muestras (Fig.3.12c) alcanzando su mínimo valor el día 14 para luego volver a aumentar levemente. Por otro lado, el análisis entre muestras al mismo tiempo de almacenamiento (Fig. 3.12c) revela que el agregado de extracto de yerba mate disminuye significativamente $(p \leq 0,05)$ la tensión de fractura solo al día 0 del almacenamiento. Luego, se observó que no existen diferencias significativas $(p \geq 0,05)$ con respecto a la muestra $L_{3}$ (sin extracto) durante el resto del tiempo de almacenamiento, excepto $L_{3} Y_{3}$ el día 21. Esto último se debe principalmente a una disminución de la tensión de fractura de la muestra control $\left(L_{3}\right)$.

Como ya se mencionó, la tensión de fractura se correlaciona inversamente con la friabilidad de un producto, lo cual hace que pueda ser reducido a partículas pequeñas ante la acción de una pequeña presión. Por ello, la yerba mate tendría entonces un efecto positivo en los primeros días al retrasar estos cambios y al aumentar la friabilidad de los snacks (menor $\varepsilon$ ), con respecto a las muestras que contenían sólo harina de lino. Esta mayor crocancia es una característica deseable en un producto de este tipo y, además, se incrementa el valor nutricional del snack por contener extractos con poder antioxidante. Por ello y sumado a sus valores adecuados de humedad y $a_{w}$, se seleccionó la formulación $\mathrm{L}_{3} \mathrm{Y}_{3}$ como producto a evaluar para determinar sus características químicas y sensoriales.

\subsection{Análisis de la microestructura de los snacks}

\subsubsection{Microscopía electrónica de barrido}

La microestructura de un material y cómo se modifica durante su procesamiento definirá las características del producto final. Por lo tanto, es esencial comprender a nivel microscópico cómo cada elemento de un sistema alimentario afecta la microestructura. La Figura 3.13 muestra la microestructura de los snacks a diferentes aumentos y composición. 

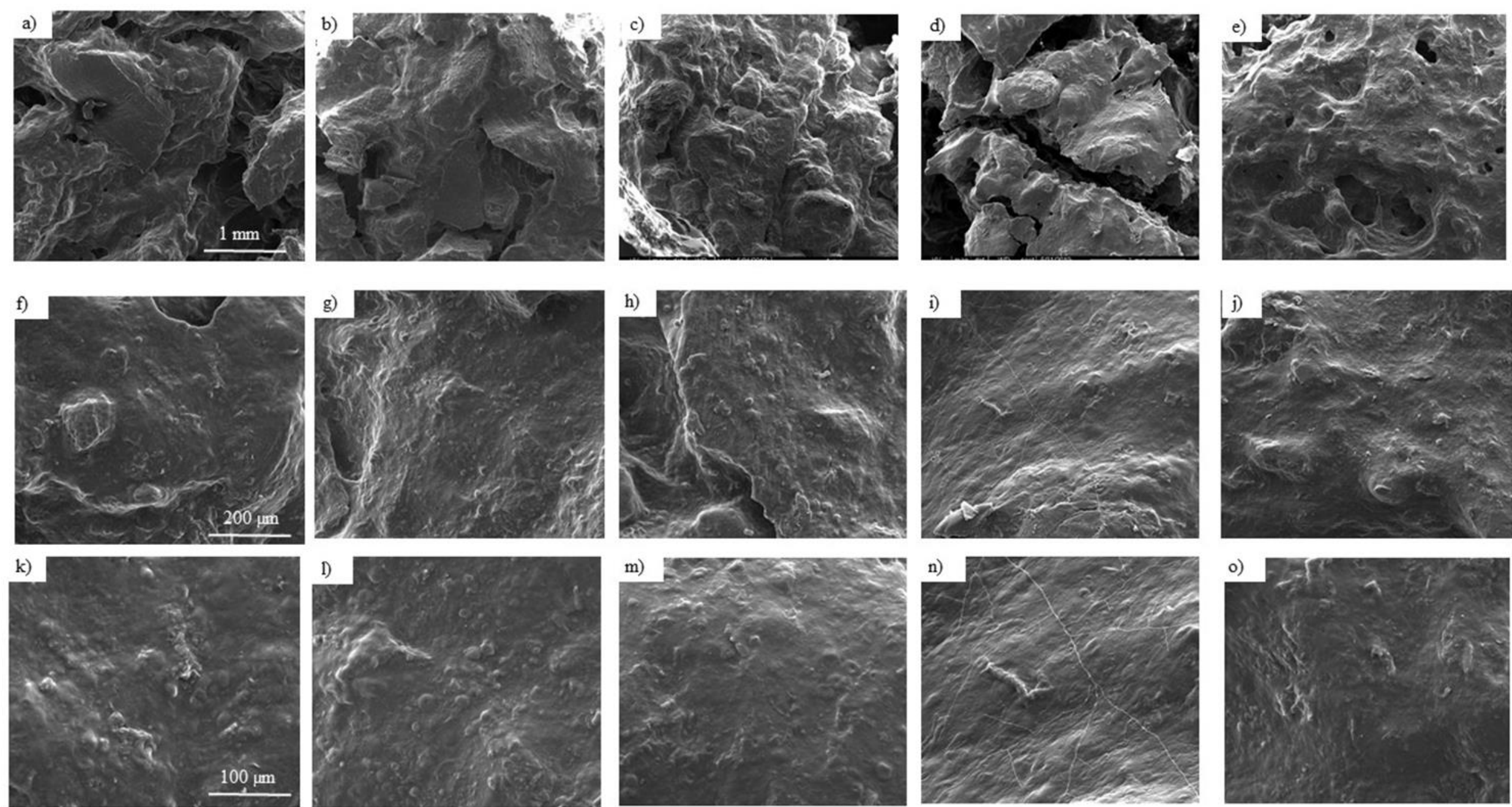

Figura 3.13. Microscopía electrónica de barrido de los snacks con distintos contenidos de harina de lino y extracto de yerba mate. Mo: (a,f,k), L3: (b,g,l), L5: (c,h,n), L3 $Y_{1}:(d, i, n), L_{3} Y_{3}:(e, j, o)$. Magnificación: 100× (a,b,c,d,e), 500× (f,g,h,i,j), 1000× (k,l,m,n,o). 
Se observa una microestructura uniforme y lisa a $500 \times$ y $1000 \times$ en todas las muestras. Por el contrario, con el aumento más bajo (100x) se presenta una estructura rugosa y no uniforme con áreas redondeadas en todas las formulaciones ensayadas, esto indica que las principales diferencias serán observadas a este aumento. La ausencia total de gránulos de almidón intactos se debe a la cocción previa del maíz y al horneado de los snacks, procesos que aseguraron la gelatinización completa de los gránulos de almidón.

La adición de harina de lino (Fig. 3.13b y c) hizo que la microestructura fuera más cerrada y compacta. Este hecho podría deberse a un aumento en la cohesividad de la microestructura debido a las proteínas y los mucílagos de la harina de lino. Este resultado confirma la menor friabilidad observada anteriormente. Cuando se agregó extracto de yerba mate (Fig. 3.13d, e, i, j, n, o), se observa una microestructura más suave en los aumentos más altos $(500 \times$ y $1000 \times)$. En la Figura $3.13 d$ se puede ver una estructura laminar que cubre algunas áreas y en la Figura 3.13 e pareciera que cubre un área más grande.

\subsubsection{Microscopía confocal laser de barrido}

Por otro lado, se analizaron las muestras de los snacks con harina de lino y extracto de yerba mate $\mathrm{L}_{3} \mathrm{Y}_{3}$ a través de microscopía confocal laser de barrido (Fig. 3.14). Toda el área roja observada en la micrografía indica la fluorescencia de la Rodamina B la cual se encuentra distribuida uniformemente en toda la estructura en una sola fase continua. Esto sugiere una distribución homogénea de los componentes estructurales de la muestra (almidón y proteínas).

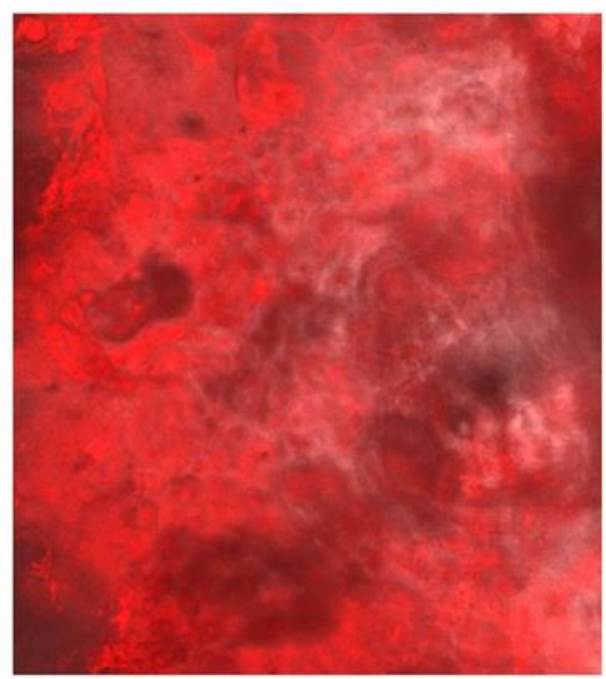

Figura 3.14. Microscopía confocal laser de barrido del snack con $3 \%$ de harina de lino y $3 \%$ de extracto de yerba mate $\left(\mathrm{L}_{3} \mathrm{Y}_{3}\right)$. 


\subsection{Composición química de los snacks con harina de lino y yerba mate}

\subsubsection{Análisis composicional}

En la Tabla 3.6 se muestran los resultados obtenidos del análisis de composición del snack con $3 \%$ de harina de lino y $3 \%$ de extracto de yerba mate $\left(L_{3} Y_{3}\right)$ comparado con el control sin harina ni extracto $\left(\mathrm{M}_{0}\right)$. Se observa que el contenido de humedad fue mayor en el snack que contenía la harina de lino (cuya humedad fue $7,38 \pm 0,12 \%$ ), atribuido a la presencia de fibra dietaria de esta harina que posee una buena capacidad de retención de agua. El contenido proteico fue mayor en el snack $\left(L_{3} Y_{3}\right)$, lo cual se explicaría teniendo en cuenta el aporte de proteína de la harina de lino $(32,54 \pm 4,98 \%)$. Bashir y col. (2006) encontraron valores menores de proteínas $(5,95 \%)$ en galletitas elaboradas con harina de trigo y $5 \%$ harina de lino partiendo de una harina de lino con $24,9 \%$ de valor proteico, lo cual denota la importancia de la calidad de la materia prima.

Tabla 3.6. Composición de los snacks de maíz: control $\left(\mathrm{M}_{0}\right)$ y con agregado de $3 \%$ de harina de lino y $3 \%$ de extracto de yerba mate $\left(\mathrm{L}_{3} \mathrm{Y}_{3}\right)$.

\begin{tabular}{ccc}
\hline Componente (\%) & Snack control $\left(\mathbf{M}_{\mathbf{0}}\right)$ & Snack $\left(\mathbf{L}_{3} \mathbf{Y}_{3}\right)$ \\
\hline Humedad & $9,74 \pm 0,95$ & $12,08 \pm 0,41$ \\
Proteínas & $6,90 \pm 0,05$ & $7,70 \pm 0,13$ \\
Lípidos & $0,15 \pm 0,04$ & $0,45 \pm 0.02$ \\
Cenizas & $0,32 \pm 0,02$ & $0,30 \pm 0,03$ \\
Fibra* & $2,7 \pm 0,00$ & $2,99 \pm 0,00$ \\
Hidratos de carbono** & $80,2 \pm 0,41$ & $76,48 \pm 0,23$ \\
\hline${ }^{*}$ Calculado por estimación a partir de datos bibliográficos (Hussain y col., 2008) \\
${ }^{* *}$ Calculado por diferencia
\end{tabular}

Con respecto al contenido de lípidos, se encontraron valores similares con el snack control ya que la harina de lino empleada para este trabajo es de otro proceso industrial en el cual se la obtiene parcialmente desgrasada $(5,15 \pm 0,62 \%)$ y la formulación no contiene otro tipo de aceites o materias grasas. Por otro lado, no se hallaron diferencias en el contenido de cenizas entre ambas formulaciones, obteniéndose valores bajos. En el caso de la fibra se estimó un valor mayor para el snack con harina de lino, como era esperado por el contenido de fibra de las semillas de lino (Tabla 1.2). Finalmente, el contenido de hidratos de carbono del snack $\left(L_{3} Y_{3}\right)$ 
determinado por diferencia fue menor que $M_{0}$, con lo cual el valor del contenido calórico de esta muestra sería también menor que el snack control.

\subsubsection{Contenido de polifenoles y flavonoides totales y actividad antioxidante (DPPH y ABTS)}

Las propiedades antioxidantes de la yerba mate se han atribuido a su alto contenido de polifenoles, especialmente ácido clorogénico, ácido cafeico y flavonoides como la quercetina, la rutina y el kaempferol (Orjuela-Palacio y col., 2014). Con el objetivo de determinar si estos compuestos activos estaban presentes en los snacks formulados, se analizó el contenido total de polifenoles y de flavonoides y la actividad antioxidante (DPPH y ABTS) del extracto puro de yerba mate y se compararon los valores obtenidos con los hallados para la muestra de mayor contenido de extracto $\mathrm{L}_{3} \mathrm{Y}_{3}$. También se analizaron el agua de cocción del maíz y los snacks control sin yerba, $M_{0}$ y $L_{3}$ a fin de cuantificar el aporte de antioxidantes del maíz y de la harina de lino y las pérdidas en el agua de cocción (Tabla 3.7).

Tabla 3.7. Contenido total de polifenoles y flavonoides y actividad antioxidante (DPPH y ABTS) en diferentes muestras.

\begin{tabular}{ccccc}
\hline Muestra & $\begin{array}{c}\text { Polifenoles totales } \\
(\mathrm{mg} \mathrm{AC} / \mathrm{g})\end{array}$ & $\begin{array}{c}\text { Flavonoides totales } \\
(\mathrm{mg} \mathrm{Cat} / \mathrm{g})\end{array}$ & $\begin{array}{c}\text { DPPH } \\
(\%)\end{array}$ & $\begin{array}{c}\text { ABTS } \\
(\mu \mathrm{molT} / \mathrm{g})\end{array}$ \\
\hline Extracto Yerba mate & $121,33 \pm 0,00^{\mathrm{a}}$ & $31,34 \pm 2,97^{\mathrm{a}}$ & $80,29 \pm 1,39^{\mathrm{a}}$ & $10,04 \pm 1,43^{\mathrm{a}}$ \\
Agua de cocción & $106,67 \pm 0,00^{\mathrm{b}}$ & $5,54 \pm 0,45^{\mathrm{b}}$ & $47,72 \pm 0,82^{\mathrm{b}}$ & $9,24 \pm 1,03^{\mathrm{a}}$ \\
Snack Mo & $\mathrm{Nd}$ & $\mathrm{Nd}$ & $\mathrm{Nd}$ & $\mathrm{Nd}$ \\
Snack $\mathrm{L}_{3}$ & $0,80 \pm 0,08^{\mathrm{d}}$ & $0,05 \pm 0,01^{\mathrm{d}}$ & $2,54 \pm 0,80^{\mathrm{d}}$ & $1,30 \pm 0,18^{\mathrm{c}}$ \\
Snack $\mathrm{L}_{3} \mathrm{Y}_{3}$ & $23,60 \pm 0,05^{\mathrm{c}}$ & $1,21 \pm 0,18^{\mathrm{c}}$ & $41,01 \pm 0,57^{\mathrm{c}}$ & $7,21 \pm 0,74^{\mathrm{b}}$
\end{tabular}

AC: ácido clorogénico, Cat: catequina, T: Trolox, Nd: no detectable.

Valores en la misma columna con letra minúscula en común no son significativamente diferentes $(p>0,05)$.

Se observa que en todas las muestras analizadas fue posible cuantificar los compuestos antioxidantes, excepto en el snack control $\mathrm{M}_{0}$ sin harina ni extracto de yerba mate. Los valores hallados para el extracto de yerba mate fueron similares a los reportados por Bastos y col. (2007), Deladino y col. (2010) y López Córdoba (2012). En el snack $\mathrm{L}_{3} \mathrm{Y}_{3}$ desarrollado se detectó una actividad antioxidante importante, cuantificada por DPPH y ABTS, aunque menor que en el extracto puro de yerba mate. 
Por otro lado, este snack presentó valores de polifenoles y flavonoides significativamente menores a los hallados en el extracto, teniendo en cuenta además que contiene, aunque mínimo, el aporte de antioxidantes de la harina de lino como lo demuestran los valores para $L_{3}$. Esto indicaría que la mayor parte de los compuestos activos antioxidantes queda en el agua de cocción del maíz y que no son absorbidos por este cereal durante el calentamiento, ni retenidos ya que no se detectaron en el snack control $\mathrm{M}_{0}$. Cabe destacar que el agua de cocción puede contener aportes de compuestos antioxidantes del propio maíz, aunque en menor magnitud comparados

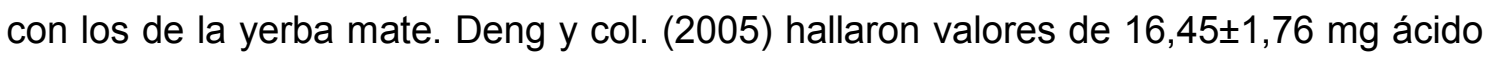
gálico/g y $67,57 \pm 1,94 \%$ DPPH en muestras de maíz colorado, como el utilizado en el presente estudio.

En cuanto a los efectos de tratamientos térmicos en líneas de producción de snack, Carunchia y col. (2015) encontraron diferencias significativas en la actividad antioxidante y concentración fitoquímica del producto final, las cuales dependen de las condiciones de procesamiento y de la naturaleza de los ingredientes. La Tabla 3.7 muestra que se hallaron valores muy bajos de flavonoides en el snack con yerba y en el agua de cocción, lo cual podría explicarse considerando que el tratamiento térmico necesario para cocinar el maíz afectaría estos compuestos. Sin embargo, el agua de cocción del maíz retuvo un alto porcentaje de polifenoles y de actividad antioxidante, por lo que el aprovechamiento de este subproducto del proceso de obtención del snack para elaborar otro alimento sería favorable desde el punto de vista nutricional.

\subsubsection{Contenido de prolaminas}

Los snacks desarrollados en este trabajo han sido formulados con ingredientes que no contienen en su composición ni trigo, avena, cebada o centeno, teniendo en cuenta a la población celíaca que no puede consumir proteínas de estos cereales. En el mercado existen ingredientes que han sido certificados como "libre de gluten" o "Sin T.A.C.C.", sin embargo, tanto el maíz como la harina de lino pueden adquirirse en dietéticas donde se almacenan y venden junto a otros ingredientes que pueden contener esas proteínas y existe el riesgo de contaminación. Por ello, a través del Servicio de determinación cuantitativa de prolaminas de la Facultad de Ciencias Exactas (UNLP) se analizó la muestra del snack $L_{3} Y_{3}$ elaborado con harina de lino certificada libre de gluten y otra muestra obtenida a partir de harina de lino a granel. En la Tabla 3.8 se observan los resultados del enzimoinmunoensayo competitivo con anticuerpos policlonales, de acuerdo con el método desarrollado por Chirdo y col. (1995). 
Tabla 3.8. Contenido de prolaminas de los snacks de maíz con agregado de $3 \%$ de harina de lino y $3 \%$ de extracto de yerba mate $\left(\mathrm{L}_{3} \mathrm{Y}_{3}\right)$, elaborados con harina de lino de diferente origen.

\begin{tabular}{cc}
\hline Muestra de Snack & $\begin{array}{c}\text { Contenido de prolaminas } \\
(\mathrm{mg} / 100 \mathrm{~g} \text { muestra })\end{array}$ \\
\hline $\mathrm{L}_{3} \mathrm{Y}_{3}$ con harina de lino certificada "Sin T.A.C.C." & $\mathrm{Nd}$ \\
$\mathrm{L}_{3} \mathrm{Y}_{3}$ con harina de lino sin certificación & 0,3 \\
\hline
\end{tabular}

Nd: no detectable.

Debido a que el producto es subdividido y analizado sobre cada uno de los componentes a través del método ELISA es posible detectar $1 \mathrm{ppm}(0,1 \mathrm{mg} / 100 \mathrm{~g}) \mathrm{de}$ gliadinas en la muestra. En el caso del snack elaborado con harina de lino sin certificar se hallaron prolaminas a un nivel que puede provocar reacciones en las personas que padecen celiaquía, por lo que es importante la verificación de las materias primas a utilizar para la declaración del producto desarrollado como libre de gluten.

\subsection{Análisis sensorial de los snacks elaborados}

Se ha visto hasta aquí que los snacks desarrollados contienen alto valor proteico y bajo contenido lipídico, características que pueden favorecer su elección por consumidores preocupados por su salud, más allá de ser aptos para el segmento de celíacos. Sin embargo, las propiedades sensoriales de los snacks serán las que finalmente determinarán su aceptación y posibilidad de compra. La Figura 3.15 muestra los atributos sensoriales (color, sabor, crocancia y aceptabilidad general) determinados en los snacks $L_{3} Y_{3}$ comparados con el control $M_{0}$.

Se observa que no se encontraron diferencias significativas $(p>0,05)$ en la crocancia y el color de las muestras, lo que sugiere que los panelistas no pudieron encontrar diferencias en la textura y apariencia visual de $M_{0}$ y $L_{3} Y_{3}$. Por otro lado, se observaron diferencias significativas $(p \leq 0,05)$ en el sabor y la aceptabilidad general, lo que indica que los panelistas prefirieron la muestra control $\left(\mathrm{M}_{0}\right)$. Este resultado sugiere que los ingredientes (harina de lino y extracto de yerba mate) afectan el sabor $y$, por lo tanto, la aceptabilidad general del producto. Resultados similares fueron hallados por Khouryieh y Aramouni (2012) en galletitas con $6 \%$ de harina de lino (como reemplazo parcial de la harina de trigo), las cuales tuvieron una aceptabilidad general entre "gusta moderadamente" y "gusta ligeramente" en una escala hedónica de 9 puntos. Dichos autores encontraron que niveles de $18 \%$ de harina de lino tuvieron un efecto negativo en la aceptación sensorial de las galletitas. 


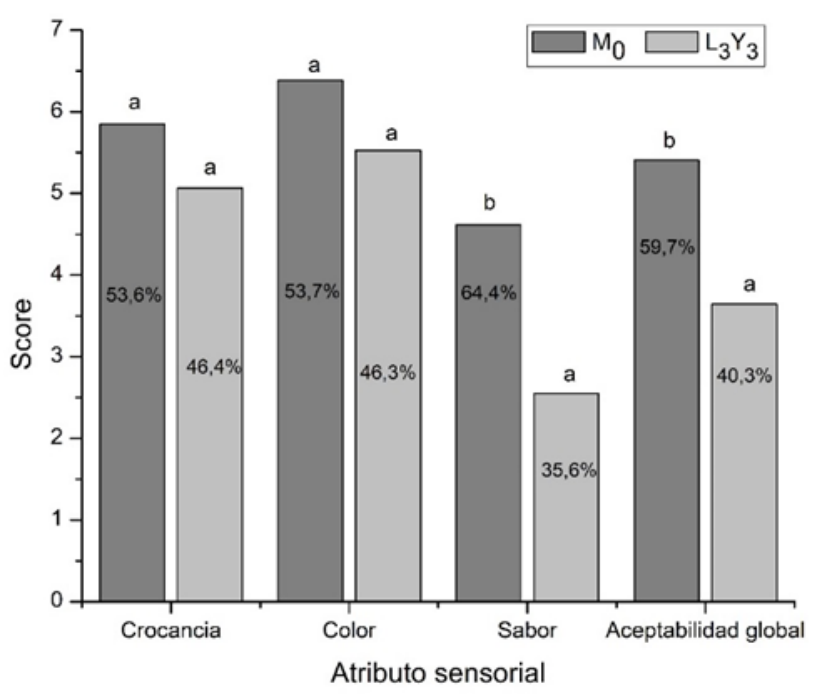

Figura 3.15. Evaluación sensorial de los snacks de maíz con agregado de $3 \%$ de harina de lino y $3 \%$ de extracto de yerba mate $\left(\mathrm{L}_{3} \mathrm{Y}_{3}\right)$.

Barras con la misma letra no son significativamente diferentes $(p>0,05)$ para cada atributo sensorial. Los valores dentro de cada barra indican el porcentaje de panelistas que prefirieron cada opción.

En el presente estudio probablemente la yerba mate contribuye con un ligero sabor amargo y astringencia, derivados de los polifenoles de su composición, que podrían explicar la elección de los panelistas. Otros autores señalan que el sabor amargo y la sensación de astringencia de las infusiones de yerba mate provocan reacciones negativas de los consumidores (Jaeger y col., 2009; Lesschaeve y Noble, 2005). Sin embargo, Dinnella y col. (2011) informaron que la intensidad de la astringencia no conduce necesariamente a la aceptabilidad de los productos. De los resultados obtenidos se desprende que el sabor es el atributo sensorial más importante que impulsaría en gran medida la aceptación del producto por parte del consumidor. Por lo tanto, el sabor debe ser optimizado y una de las posibilidades es el agregado de sal a los snacks, ya que algunos de los panelistas expresaron que un sabor salado era el esperado. La optimización de la formulación implica evaluar, además de las propiedades sensoriales, las modificaciones en las características fisicoquímicas y de textura de la pasta y de los snacks debidas a la incorporación del nuevo ingrediente. 


\subsection{CONCLUSIONES PARCIALES}

Los snacks formulados con harina de maíz poseen propiedades estructurales y funcionales que dependen, entre otros, de la presencia de otros componentes como la harina de lino y la yerba mate. El aumento de la concentración de harina de lino en la formulación incrementó el porcentaje de humedad debido a que el contenido de fibra presente en la harina aumenta la capacidad de retención de agua. Los incrementos en la actividad acuosa estarían relacionados con los procesos de retrogradación del almidón que ocurren en los primeros 14 días y la migración de agua entre los diferentes componentes de la matriz del alimento, como las proteínas, almidón, mucílagos y compuestos antioxidantes (polifenoles y flavonoides). En cuanto al color del producto se observó corrimientos de la zona de los rojos y amarillos cuando se agregó la harina de lino y un mayor desplazamiento cuando se agregó los extractos de yerba mate. Además, la yerba mate tornó los snacks más oscuros, aunque no se encontraron diferencias significativas entre las distintas concentraciones ensayadas de este componente.

Con respecto a la textura de los snacks se encontró que el estrés de fractura disminuyó, para todas las formulaciones (excepto $L_{3}$ ) a todos los tiempos ensayados, con el agregado de harina de lino haciendo menos rígida la estructura. Un comportamiento similar se observó con el agregado del extracto de yerba mate. El módulo elástico mostró una tendencia general a disminuir en todas las muestras cuando se agregó harina de lino, al igual que cuando se analizó en función del tiempo. El agregado de extracto de yerba mate hizo a las muestras mucho más rígidas, especialmente hacia la mitad del tiempo de almacenamiento. La tensión de fractura aumentó con el agregado de harina de lino (excepto $L_{3}$ que disminuyó) durante la primera semana de almacenamiento indicando que el producto se volvería menos friable con una mayor cohesividad estructural. Sin embargo, en la segunda semana la tensión de fractura disminuyó respecto de la muestra control. El efecto contrario se observó con el agregado del extracto de yerba mate, el cual disminuyó la tensión de fractura haciéndolas más friables durante las dos primeras semanas. Estos cambios de textura que se observan durante los primeros días de almacenamiento hacen que se deba prestar mucha atención respecto a los tiempos que transcurren entre la fabricación del producto y su comercialización, pues podría suceder que el consumidor los adquiriera con una textura que sea rechazada. 
Por otro lado, se halló actividad antioxidante en el producto final, si bien una importante cantidad de polifenoles y flavonoides quedó en el líquido de cocción del maíz permaneciendo retenida una fracción menor en el snack. El análisis por microscopía electrónica de barrido reveló que los snacks formulados presentan una microestructura menos uniforme y más fragmentada con algunos poros visibles, La microscopía confocal laser de barrido demostró una distribución homogénea de los componentes estructurales de la muestra (almidón y proteínas).

Con respecto a la composición, en el snack formulado se encontraron valores levemente mayores de proteínas y humedad y menores de glúcidos y energía aportada. La suplementación de estos productos tipo snacks, con harinas de lino y extracto de yerba mate con fines de enriquecimiento, estará limitada por el porcentaje en el cual se pueda agregar al sistema. La obtención de valores deseados en parámetros importantes de conservación, como lo son contenidos de humedad y actividad de agua, estará relacionada con la capacidad de retención de agua de las materias primas empleadas para la elaboración de dichos productos. De igual manera este porcentaje también influye en los parámetros sensoriales de aceptabilidad como color, sabor y textura. Asimismo, es un desafío encontrar las mejores fuentes y formas de introducir en este tipo de alimentos componentes importantes como los antioxidantes para que no se pierdan en procesos de elaboración y lograr incorporarlos sin que se vea afectado el sabor del producto. 
Capítulo 4

Aprovechamíento del claro de maíz para la generación de un postre 


\subsection{Evaluación del agregado de concentrado de proteínas de suero lácteo al claro de maíz}

A partir del agua de cocción del maíz (claro de maíz), utilizado para elaborar el snack y que contiene $3 \%$ de extracto de yerba mate, se buscó formular un alimento tipo postre gelificado, agregando harina de lino, proteínas de suero lácteo y miel. La formación de un gel depende de varios factores tales como la concentración de proteínas, $\mathrm{pH}$, fuerza iónica y la presencia de otros componentes del alimento. Como ya se mencionó, una de las propiedades funcionales característica del concentrado de proteínas lácteas (CPL) es la capacidad de formar geles por calentamiento de sus dispersiones acuosas. Para determinar la cantidad mínima de CPL que gelifique con el calentamiento a $90^{\circ} \mathrm{C}$, se ensayaron tres niveles de concentración 5,7 y $9 \% \mathrm{p} / \mathrm{p}$ respecto al claro de maíz.

Schmidt y col. (1978) hallaron que la mínima concentración de proteína de lactosuero requerida para formar un gel fuerte es de $7,5 \%$ de proteína o mayor, en medio acuoso. Como en el presente trabajo se parte del claro de maíz que contiene almidón, se esperaba que a la concentración de 5\% p/p de CPL se pudiera formar el gel ya que el nivel de sólidos es mayor en la solución. Sin embargo, el gel no se formó completamente a dicha concentración, presentando además sinéresis.

La formación de geles de proteína de lactosuero inducidos por calor implica desplegamiento de la proteína y la agregación como los procesos primarios. Un gel se forma cuando la extensión de la agregación excede un cierto nivel crítico formando una red tridimensional autoportante que atrapa el disolvente del sistema. Cuando el grado de agregación es inferior a cierto nivel crítico, se forman agregados solubles o un precipitado. Por lo tanto, la formación de gel y las propiedades del gel dependen del tipo y número de interacciones proteína-proteína que a su vez se ven afectados por variables tales como el tipo y la concentración de proteína, temperatura, $\mathrm{pH}$, fuerza iónica y la presencia de otros componentes del alimento. En el presente caso, el contenido de almidón del claro de maíz no fue suficiente para formar un gel fuerte a la concentración de $5 \% \mathrm{p} / \mathrm{p}$ de CPL. Por otro lado, la presencia del extracto de yerba mate en el claro de maíz podría interferir en la formación del gel debido a la formación de complejos entre el almidón y los polifenoles que impiden la alineación de las cadenas que forman la red tridimensional del gel (Beta y Corke, 2004, Wu y col., 2016).

Al nivel de $7 \%$ p/p del concentrado proteico se formó un gel débil con poca sinéresis y pérdida de agua al corte. Finalmente, la concentración de 9\% p/p de CPL fue la adecuada para obtener un gel firme sin sinéresis. Debido a que la formulación 
final del postre debía contener además harina de lino y miel, los cuales aportan a la textura del sistema, se elaboraron también geles a base de claro de maíz con $7 \%$ p/p de CPL.

\subsection{Análisis reológico de los geles obtenidos}

\subsubsection{Efecto del agregado de harina de lino y de las condiciones del proceso}

En la Figura 4.1 se muestran los espectros mecánicos de los geles a base de claro de maíz, con 7\% p/p CPL y con el agregado de la harina de lino (HL) sin y con precalentamiento (HLp), comparados con aquellos con $9 \% \mathrm{p} / \mathrm{p}$ CPL. También se muestra el efecto del almacenamiento a $0^{\circ} \mathrm{C}$ durante 0,7 y 14 días. En todos los casos analizados se observa una dependencia de ambos módulos, viscoso G" y elástico G', con la frecuencia de oscilación. El módulo elástico se mantuvo por encima del módulo viscoso correspondiente, a todas las frecuencias ensayadas, lo que indicaría un comportamiento predominantemente de carácter sólido para todas las muestras. Wang y col. (2008), ensayando mezclas de geles de almidón de maíz nativo con goma de semilla de lino (mucílago), también encontraron que su comportamiento era similar a un gel y que su módulo elástico G' era mayor que su módulo viscoso G”. Este mismo resultado también fue observado para varios tipos de hidrocoloides mezclados con almidón de maíz (Ptaszek y col., 2007; Holser y col., 2000; Freitas y col., 2003).

Los resultados muestran que los geles con $9 \% \mathrm{p} / \mathrm{p}$ de proteínas presentaron valores de G' y G" mayores que aquellos preparados con $7 \%$ p/p de proteínas y este comportamiento se mantuvo durante el almacenamiento a $0^{\circ} \mathrm{C}$ (Fig. 4.1). Por otro lado, los antioxidantes de la yerba mate (polifenoles y flavonoides que se encuentran en el claro de maíz) podrían influir en las características reológicas de estos geles. Esta hipótesis se sostendría en el hecho de que von Staszewski (2011) reportó que los polifenoles de un extracto de té verde al $1 \% \mathrm{p} / \mathrm{v}$ poseen una fuerte afinidad por las proteínas del lactosuero acelerando el proceso de gelificación y aumentando el valor del módulo elástico en un $30 \%$. 

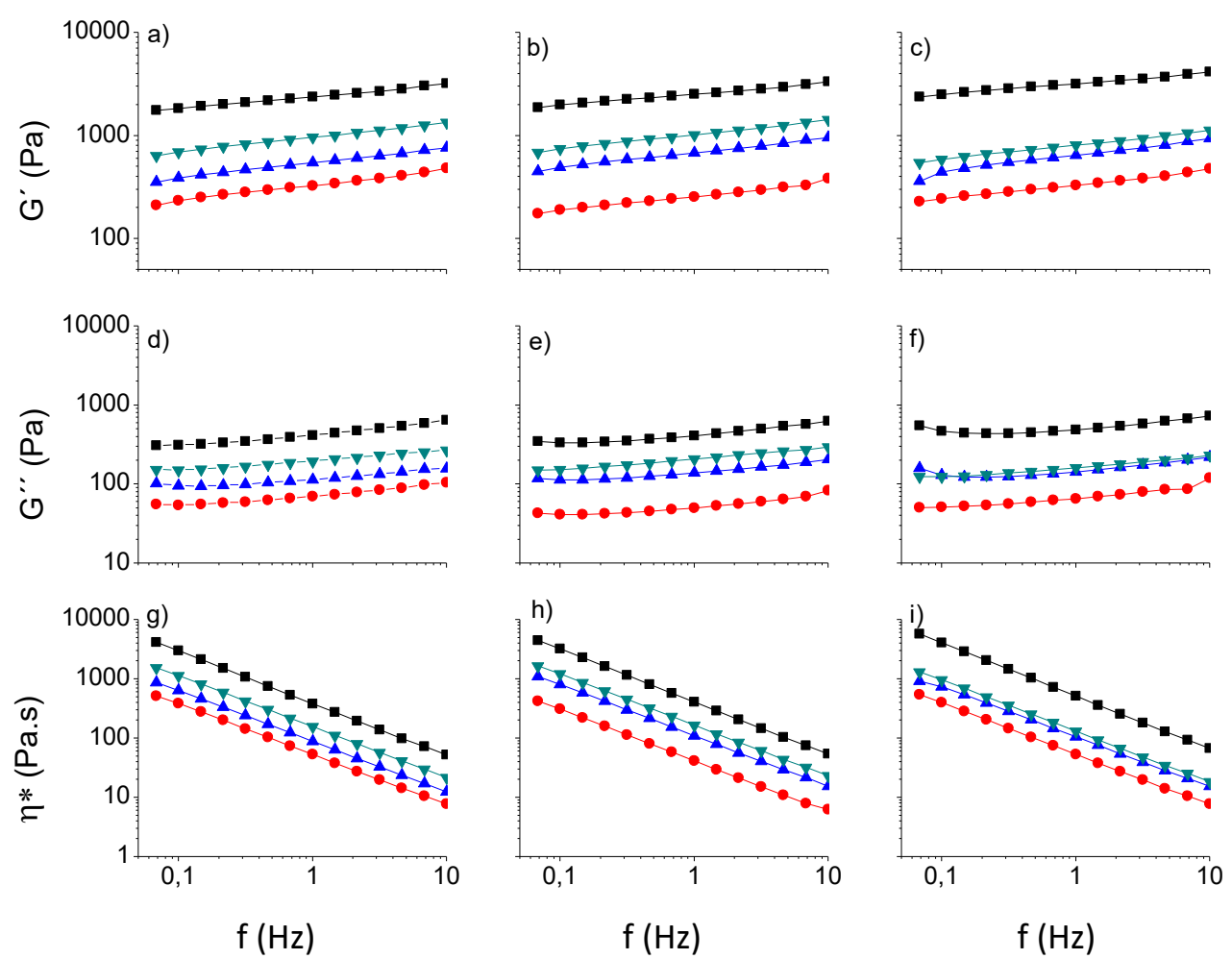

Figura 4.1. Espectro mecánico de los geles a base de claro de maíz con: (ø) 9\%CPL; $(\bullet)$ $7 \% \mathrm{CPL} ;(\boldsymbol{\Delta}) 7 \% \mathrm{CPL}+\mathrm{HL},(\boldsymbol{\nabla}) 7 \% \mathrm{CPL}+\mathrm{HLP}$ almacenados a $0^{\circ} \mathrm{C}$ durante $0(\mathrm{a}, \mathrm{d}, \mathrm{g}), 7(\mathrm{~b}, \mathrm{e}, \mathrm{h})$ y 14 (c, f, i) días.

Los resultados de la Figura 4.1a,d muestran que la incorporación de harina de lino incrementó los valores de los módulos G' y G" de los geles, respecto del tratamiento que no la contenía, siendo aún mayores significativamente cuando se realiza el precalentamiento de la muestra con la harina de lino (Sección 2.3.2., Materiales y métodos). La viscosidad compleja muestra también un aumento con el agregado de harina de lino y con el precalentamiento de ésta (Fig.4.1g). Estos comportamientos pueden ser atribuidos al aporte de almidón y de mucílago y a la interacción de éstos con los demás componentes de la muestra ayudando a formar geles más fuertes. El almidón contribuiría al comportamiento sólido de los geles como resultado del proceso de gelatinización durante el precalentamiento de la mezcla con harina (Yamul y Lupano., 2009). Además, diferentes autores (Hesarinejad y col., 2018, Capitani y col., 2015, Naji-Tabasi y col., 2017, Yu y col., 2017) han reportado que, por la variedad conformacional de su estructura, los mucílagos de lino son espesantes y gelificantes. Esta capacidad se debería a interacciones intramoleculares de sus grupos laterales de la cadena polimérica mediante enlaces hidrógeno e interacciones hidrofóbicas. En cuanto a la pseudoplasticidad que aportan los mucílagos al sistema, estos mismos 
autores encontraron que es debido a la capacidad de las cadenas de estos polímeros para someterse a la alineación en la dirección del flujo. Por su parte, Shi y BeMiller (2002), Fedeniuk y col. (1994) y Wang y col. (2008) encontraron, en dispersiones de almidón-mucílago de lino, que los valores de G' y G" y la viscosidad compleja de las mezclas aumentaba con el incremento de la concentración del mucílago $(0,1-0,5 \%)$.

La interacción entre almidones, hidrocoloides y mucílagos ha sido demostrada a través de diferentes estudios. Rivera-Corona y col. (2014), trabajando con almidón de sorgo y mucílago de cactus, demostraron por difracción de rayos $\mathrm{X}$ las interacciones puente hidrógeno entre el almidón y el mucílago obteniendo geles más firmes (mayor G'). Por otro lado, Tavares y da Silva (2003) reportaron un aumento en la rigidez de geles de proteínas de lactosuero con la adición de galactomananos en soluciones acuosas, relacionándose este hecho, con una disminución de la movilidad molecular de la red de proteínas, donde el polisacárido actúa como un agente de relleno en la organización estructural del gel.

En la Fig. 4.1 puede observarse que el agregado de harina de lino, en las concentraciones ensayadas, tampoco fue suficiente para obtener geles de las características reológicas del que contenía mayor concentración de CPL ( $9 \%$ p/p). Esto indicaría que la concentración de proteínas tiene más peso en la fuerza del gel que la concentración de harina de lino sobre los valores de ambos módulos.

Luego de 7 y 14 días de almacenamiento a $0^{\circ} \mathrm{C}$ se encontró que los módulos G' y G" disminuyen en todos los sistemas ensayados, sin embargo, dicha disminución es menor en los sistemas con harina de lino. Además de las proteínas de la harina, sus mucílagos tienen también alta capacidad de retención de agua, lo que ayudaría a la estabilidad de los geles. Respecto a la viscosidad compleja, durante el almacenamiento se observa una leve tendencia de este parámetro a incrementarse (Fig. 4.1g,h,i). Esto podría explicarse teniendo en cuenta que durante el almacenamiento la estructura del gel exuda agua por sinéresis, lo que incrementaría las fricciones moleculares, aumentando así la viscosidad.

\subsubsection{Efecto del agregado de miel}

En la Fig. 4.2 se muestran los espectros mecánicos de los geles con miel comparados con el control sin miel. Con el agregado de miel se observó una disminución de G', G" y de la viscosidad compleja, mostrando que este ingrediente genera estructuras gelificadas más débiles en los sistemas que la contienen. Esto se explicaría considerando que los azúcares de la miel compiten con las proteínas, el almidón y los mucílagos por el agua disponible para la formación de puentes 
hidrógeno. Yamul y Lupano. (2003, 2005 y 2009) observaron un comportamiento similar en geles de proteínas de lactosuero con miel.
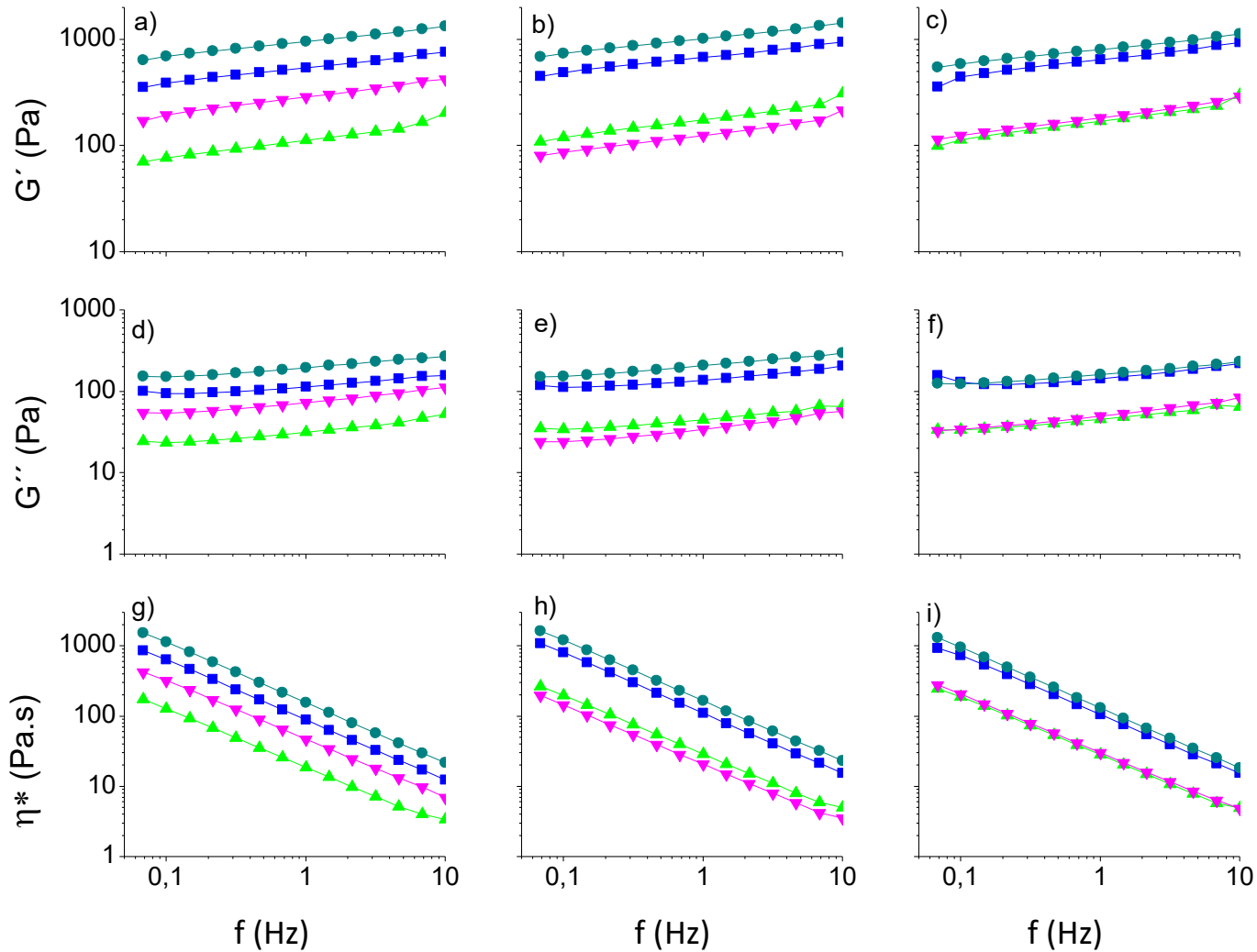

Figura 4.2. Espectro mecánico de los geles a base de claro de maíz con: (๑) 7\%CPL+HL; (•) $7 \% \mathrm{CPL}+\mathrm{HLp},(\triangle) 7 \% \mathrm{CPL}+\mathrm{HL}+\mathrm{MIEL},(\nabla) 7 \% \mathrm{CPL}+\mathrm{HLp}+\mathrm{MIEL}$, almacenados a $0^{\circ} \mathrm{C}$ durante $0(\mathrm{a}$, d, g), 7 (b, e, h) y 14 (c, f, i) días.

Es interesante también destacar que el efecto de disminución de G' en el tiempo se observa a partir del día 7 en el tratamiento que contenía la miel y el precalentamiento (Fig. 4.2b), con igual tendencia en el módulo G” (Fig. 4.2e). Estos geles con miel presentaron sinéresis desde el día 7 con pérdida de agua luego del corte. En cuanto a la viscosidad compleja, cuando se comparan los tratamientos con miel con los que no la contienen, se observa una disminución de este parámetro, debido a la mayor retención de agua, que estará distribuida entre los ingredientes que componen el gel. Durante el almacenamiento la viscosidad aumento para todos los tratamientos, debido a la liberación de agua de la red.

Aquellos tratamientos con miel presentaron diferencias significativamente menores con los tratamientos que no la contenían. 


\subsection{Determinación de las características texturales de los geles}

\subsubsection{Efecto de la harina de lino sin y con precalentamiento}

En la Tabla 4.1 se observa que el gel control presentó valores de fuerza máxima más bajos respecto a los demás geles con el menor valor para el día 0 , el cual luego aumentó significativamente $(p \leq 0,05)$ durante el almacenamiento.

Tabla 4.1. Efecto de la composición y de las condiciones de proceso sobre los parámetros de textura de geles de claro de maíz, $7 \% \mathrm{CPL}$ y harina de lino almacenados a $0^{\circ} \mathrm{C}$.

Control $(7 \% \mathrm{CPL}), \mathrm{HL}$ ( $7 \% \mathrm{CPL}+$ harina de lino sin precalentamiento) y HLp (7\%CPL+harina de lino con precalentamiento). F: fuerza máxima, E: módulo de Young.

\begin{tabular}{ccccc}
\hline \multirow{2}{*}{ Parámetro } & Gel & \multicolumn{3}{c}{ Tiempo de almacenamiento (días) } \\
& & 0 & 7 & 14 \\
\hline F $(\mathrm{N})$ & control & $0,10 \pm 0,001^{\mathrm{A}, \mathrm{a}}$ & $0,14 \pm 0,001^{\mathrm{B}, \mathrm{a}}$ & $0,14 \pm 0,003^{\mathrm{B}, \mathrm{a}}$ \\
& $\mathrm{HL}$ & $0,23 \pm 0,003^{\mathrm{B}, \mathrm{c}}$ & $0,19 \pm 0,002^{\mathrm{A}, \mathrm{b}}$ & $0,19 \pm 0,005^{\mathrm{A}, \mathrm{b}}$ \\
& $\mathrm{HLp}$ & $0,16 \pm 0,003^{\mathrm{A}, \mathrm{b}}$ & $0,20 \pm 0,000^{\mathrm{B}, \mathrm{c}}$ & $0,26 \pm 0,018^{\mathrm{C}, \mathrm{c}}$ \\
$\mathrm{E}(\mathrm{kPa})$ & control & $15 \pm 0,000^{\mathrm{A}, \mathrm{a}}$ & $32 \pm 0,006^{\mathrm{B}, \mathrm{a}}$ & $34 \pm 0,005^{\mathrm{B}, \mathrm{a}}$ \\
& $\mathrm{HL}$ & $34 \pm 0,017^{\mathrm{A}, \mathrm{b}}$ & $51 \pm 0,007^{\mathrm{B}, \mathrm{b}}$ & $191 \pm 0,129^{\mathrm{C}, \mathrm{c}}$ \\
& $\mathrm{HLp}$ & $33 \pm 0,008^{\mathrm{A}, \mathrm{b}}$ & $50 \pm 0,000^{\mathrm{B}, \mathrm{b}}$ & $81 \pm 0,001^{\mathrm{C}, \mathrm{b}}$
\end{tabular}

Valores con la misma letra mayúscula en la misma fila y con letra minúscula en la misma columna para cada parámetro no son significativamente diferentes $(p>0,05)$.

Por otro lado, al inicio del almacenamiento el valor de fuerza máxima fue menor para el gel con precalentamiento respecto al no tratado, luego este valor aumentó significativamente $(p \leq 0,05)$ durante el almacenamiento. En cambio, la muestra sin precalentamiento presentó un comportamiento opuesto, con un valor de fuerza máxima mayor al día 0, para luego disminuir en el tiempo. Resultados similares encontraron Chen y col. (2006) al aumentar la temperatura de la preparación de geles de lino. Estos autores encontraron un aumento de la fuerza máxima del gel para valores de $\mathrm{pH}$ entre 2 y 6 , lo cual explica que el gel HLp presente una fuerza máxima mayor que los demás tratamientos, ya que se incorporó primero la harina de lino con precalentamiento al agua proveniente de la cocción la cual tenía un valor de $\mathrm{pH}=5,32$. BeMiller (2011) plantea en su revisión de trabajos que los mecanismos involucrados serian la interacción de moléculas de hidrocoloides (mucílago de lino en el caso del presente trabajo) con moléculas de amilosa lixiviado, incrementando y reforzando la formación de la red de almidón. $\mathrm{A}$ este $\mathrm{pH}$, las proteínas del CPL contribuyen a la fuerza del gel a través de enlaces puente hidrógeno. 
Respecto al módulo de Young, la Tabla 4.1 muestra que para todas las muestras ensayadas este parámetro se incrementó significativamente $(p \leq 0,05)$ con el tiempo de almacenamiento y con el agregado de harina de lino, sugiriendo que las muestras se vuelven más rígidas. El efecto del precalentamiento de la harina no mostró diferencias significativas entre las muestras, excepto al día 14 donde se observó una disminución del módulo de Young.

\subsubsection{Efecto del agregado de miel a los geles con harina de lino y CPL}

En la Tabla 4.2 se observa que para el valor de fuerza máxima el agregado de miel disminuyó significativamente $(p \leq 0,05)$ la fuerza de los geles en todas las condiciones ensayadas indicando que la miel debilita la estructura de estos sistemas. Este resultado coincide con los ensayos de reología donde se observó que la miel disminuye el módulo G’ (sección 4.2). Además, confirma los resultados previos obtenidos por Yamul y col. (2003, 2005 y 2009) quienes encontraron que la miel modifica el comportamiento reológico de los geles preparados con CPL a través de su capacidad de formar puentes de hidrógeno y genera estructuras más débiles. Estos autores encontraron también que la miel ejerce un efecto de protección sobre la desnaturalización térmica de las proteínas.

Tabla 4.2. Efecto del agregado de miel a geles de claro de maíz con 7\%CPL y harina de lino con precalentamiento sobre los parámetros de textura durante el almacenamiento a $0^{\circ} \mathrm{C}$.

HLp ( $7 \% \mathrm{CPL}+$ harina de lino con precalentamiento), HLpM ( $7 \% \mathrm{CPL}+$ harina de lino con precalentamiento + miel). F: fuerza máxima, E: módulo de Young.

\begin{tabular}{ccccc}
\hline \multirow{2}{*}{ Parámetro } & Gel & \multicolumn{3}{c}{ Tiempo de almacenamiento (días) } \\
& & 0 & 7 & 14 \\
\hline $\mathrm{F}(\mathrm{N})$ & HLp & $0,16 \pm 0,003^{\mathrm{A}, \mathrm{b}}$ & $0,20 \pm 0,000^{\mathrm{B}, \mathrm{b}}$ & $026 \pm 0,018^{\mathrm{C}, \mathrm{b}}$ \\
& HLpM & $0,11 \pm 0,012^{\mathrm{A}, \mathrm{a}}$ & $0,12 \pm 0,012^{\mathrm{A}, \mathrm{a}}$ & $0,12 \pm 0,007^{\mathrm{A}, \mathrm{a}}$ \\
$\mathrm{E}(\mathrm{kPa})$ & HLp & $33 \pm 0,008^{\mathrm{A}, \mathrm{b}}$ & $50 \pm 0,000^{\mathrm{B}, \mathrm{b}}$ & $81 \pm 0,001^{\mathrm{C}, \mathrm{b}}$ \\
& HLpM & $21 \pm 0,004^{\mathrm{A}, \mathrm{a}}$ & $28 \pm 0,001^{\mathrm{A}, \mathrm{a}}$ & $26 \pm 0,000^{\mathrm{A}, \mathrm{a}}$ \\
\hline
\end{tabular}

Valores con la misma letra mayúscula en la misma fila y con letra minúscula en la misma columna para cada parámetro no son significativamente diferentes $(p>0,05)$.

Por otro lado, se observa que el módulo de Young de los geles con miel no se modificó significativamente durante el tiempo de almacenamiento ensayado, pero sí presentó valores menores que sus contrapartes sin miel. Estos resultados indican que la miel disminuye la rigidez de las muestras, coincidiendo con los resultados obtenidos en los otros ensayos. 


\subsection{Color de los geles}

La Figura 4.3a muestra que el agregado de harina de lino a los geles con 7\% p/p CPL aumentó el parámetro $a^{*}$ (disminución del color verde) y disminuyó la luminosidad $L^{*}$ de éstos. Esto se debería al color marrón oscuro de la harina de lino. El color verde es aportado por el extracto de la yerba mate con el cual se cocinó el maíz. Por otro lado, no se encontraron diferencias significativas $(p>0,05)$ entre los parámetros de color de los geles obtenidos sin y con precalentamiento de la harina de lino.

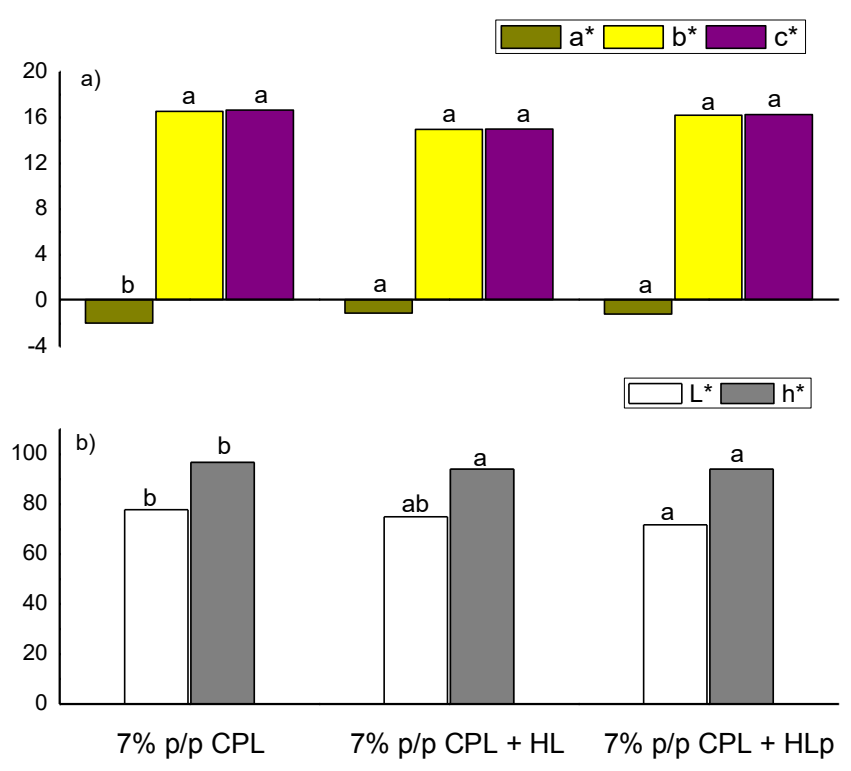

Figura 4.3. Efecto de la harina de lino sin y con precalentamiento sobre los parámetros de color de geles a base de claro de maíz.

Barras con una letra común en un mismo gráfico no son significativamente diferentes $(p>0,05)$.

Respecto al agregado de miel, se observa una disminución significativa de los parámetros $a^{*}$ y $h^{*}$ (Figura 4.4b) de los geles, indicando un corrimiento hacia la zona del rojo, dado por las reacciones de Maillard favorecidas por presencia de azúcares reductores en la miel. 


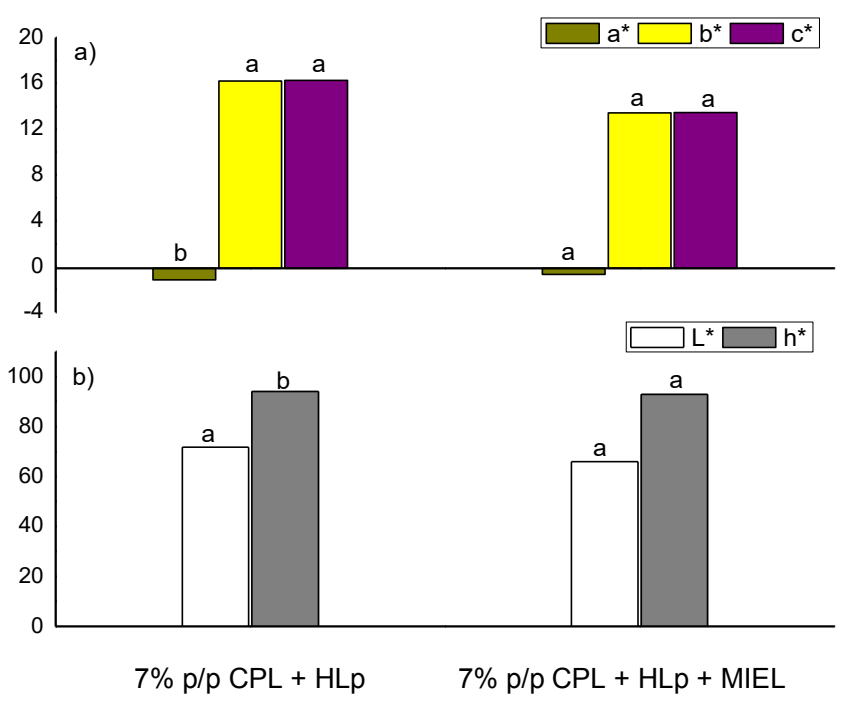

Figura 4.4. Efecto de la harina de lino con precalentamiento y de la miel sobre los parámetros de color de geles a base de claro de maíz.

Barras con una letra común en un mismo gráfico no son significativamente diferentes $(p>0,05)$.

\subsection{Capacidad de retención de agua de los geles}

La Tabla 4.3 muestra que la capacidad de retención de agua (CRA) de los geles obtenidos a partir del claro de maíz, CPL y harina de lino presentó una tendencia de incremento en el almacenamiento a $0^{\circ} \mathrm{C}$, si bien no mostró diferencias significativas $(p$ $>0,05)$ hasta el día 14. Los geles proteicos están constituidos por una matriz de cadenas de proteínas donde se encuentra ocluida la fase acuosa (Standing y col., 1993), así el agua retenida está inmovilizada físicamente por la estructura proteica y no puede ser expulsada por presión. Además, se puede ligar agua a través de los poros de la red proteica que pueden retener agua por fenómenos de capilaridad (Cheftel y col., 1993). Los cambios que ocurren durante el almacenamiento en la estructura del almidón del maíz y de la harina de lino, a través del fenómeno de retrogradación, pueden incrementar los grupos $\mathrm{OH}$, aumentando así la formación de puentes de hidrógeno y, por ende, la capacidad de retener agua en la estructura. 
Tabla 4.3. Capacidad de retención de agua de geles a base de claro de maíz, 7\%CPL, harina de lino y miel almacenados a $0^{\circ} \mathrm{C}$.

HLp (7\%CPL+harina de lino con precalentamiento), HLpM (7\%CPL+harina de lino con precalentamiento + miel).

Capacidad de retención de agua (\%)

Gel

Tiempo de almacenamiento (días)

0 7 14

HLp

$66,48 \pm 2,12^{\mathrm{Aa}}$

$80,96 \pm 2,12^{\mathrm{A}, \mathrm{a}}$

$78,29 \pm 7,8^{\mathrm{A}, \mathrm{a}}$

HLpM

$68,50 \pm 2,31^{\mathrm{A}, \mathrm{a}}$

$84,54 \pm 2,72^{\mathrm{B}, \mathrm{a}}$

$69,72 \pm 3,42^{\text {Aa }}$

Valores con la misma letra mayúscula en la misma fila y con letra minúscula en la misma columna no son significativamente diferentes $(p>0,05)$.

Por otro lado, el agregado de miel no aumentó significativamente $(p>0,05)$ la CRA de los geles y esta tendencia se mantuvo durante el almacenamiento a $0^{\circ} \mathrm{C}$, excepto al día 7 donde se observaron diferencias significativas $(p \leq 0,05)$ entre ambos geles $\sin y$ con miel. Estos resultados confirmarían la información existente en bibliografía (Yamul y col., 2003) respecto a la capacidad de la miel, al igual que el almidón, de formar puentes hidrógeno con moléculas de agua, incrementando la CRA de los geles de CPL. Estos autores encontraron un incremento en la capacidad de retención de agua en geles de CPL con agregado de miel en diferentes rangos de $\mathrm{pH}$ ensayados, siendo menor la CRA a $\mathrm{pH} 4,2$, donde el efecto de la miel es más importante.

\subsection{Composición química del postre desarrollado}

\subsubsection{Análisis composicional}

La Tabla 4.4 muestra la información nutricional del producto desarrollado con CPL, harina de lino y miel, y la de un postre lácteo comercial libre de gluten. Se encontró que los valores de proteína y cenizas en el postre desarrollado fueron mayores que en el comercial, mientras que los contenidos de lípidos y glúcidos fueron menores.

El postre comercial es un producto a base de leche y crema, con el consecuente aporte de proteínas y lípidos. en cambio, en el postre desarrollado el aumento del contenido proteico está relacionado con la cantidad de proteína presente en el concentrado de suero lácteo, además de la contenida en la harina de lino. El aporte de lípidos es bajo en el postre desarrollado debido a que la harina de lino es desgrasada y el resto de los componentes (CPL y miel) no aportan lípidos en cantidades significativas. 
Tabla 4.4. Comparación de la Información nutricional del postre desarrollado y un postre comercial (marca: Serenito Crash, sabor vainilla). Valores por cada 100 gramos de muestra.

\begin{tabular}{lcc}
\hline & Postre desarrollado & Postre comercial \\
\hline Humedad (\%) & $75,99 \pm 0,02$ & 74,1 \\
Proteínas (\%) & $20,35 \pm 1,47$ & 3,5 \\
Lípidos (\%) & $0,14 \pm 0,01$ & 2,7 \\
Cenizas (\%) & $0,31 \pm 0,04$ & 0,23 \\
Hidratos de carbono (\%) & $3,24 \pm 1,52^{*}$ & 19,5 \\
\hline
\end{tabular}

La diferencia entre ambos productos respecto a los hidratos de carbono se debe a que el postre comercial contiene almidones modificados como agentes de textura del gel proteico, por lo que su contenido de glúcidos es mayor y, por ende, también su valor energético.

\subsubsection{Determinación del contenido de polifenoles totales de los geles}

La Tabla 4.5 muestra que el contenido de polifenoles totales disminuyó significativamente en el producto final, probablemente como consecuencia del tratamiento térmico para su obtención, como se observó en el caso del snack.

Tabla 4.5. Contenido de polifenoles totales (PFT) en diferentes muestras.

\begin{tabular}{cc}
\hline Muestras & PFT (mg.ác.clorogénico/g) \\
\hline Extracto de yerba mate & $121,33 \pm 0,00$ \\
Claro de maíz & $106,67 \pm 0,00$ \\
Postre & $2,08 \pm 0,100$ \\
\hline
\end{tabular}

Por otro lado, von Staszewski (2011) encontró una fuerte afinidad entre los polifenoles de diferentes muestras de té verde por las proteínas del lactosuero llevando a la formación de complejos que disminuyen la actividad antimicrobiana y antioxidante de dichos tés. En coincidencia, Arts y col. $(2001,2002)$ reportaron que la unión de las proteínas con los flavonoides puede afectar la capacidad antioxidante de estos últimos mediante la reducción del número de grupos hidroxilo libres y/o por precipitación de los complejos formados. Por lo tanto, dichos comportamientos podrían explicar, al menos en parte, los resultados obtenidos en el presente trabajo respecto a la reducción del contenido de polifenoles observado en los geles. 


\subsection{Análisis sensorial del postre desarrollado}

De todos los atributos sensoriales la firmeza fue la mejor evaluada por los panelistas, no observándose grandes diferencias entre el resto de los atributos (Fig. 4.5). Cabe destacar que el dulzor no obtuvo una puntuación muy alta a pesar de la presencia de miel, esto se debe a que los polifenoles (provenientes principalmente de la yerba mate) confieren al alimento una percepción amarga, limitando así la aceptabilidad de los productos. Ares y col. (2010) encontraron, para un postre de chocolate con leche en el que se incorporó antioxidantes, que los niveles más altos de adición de polifenoles daban como resultado puntuaciones bajas en la escala hedónica de aceptabilidad.

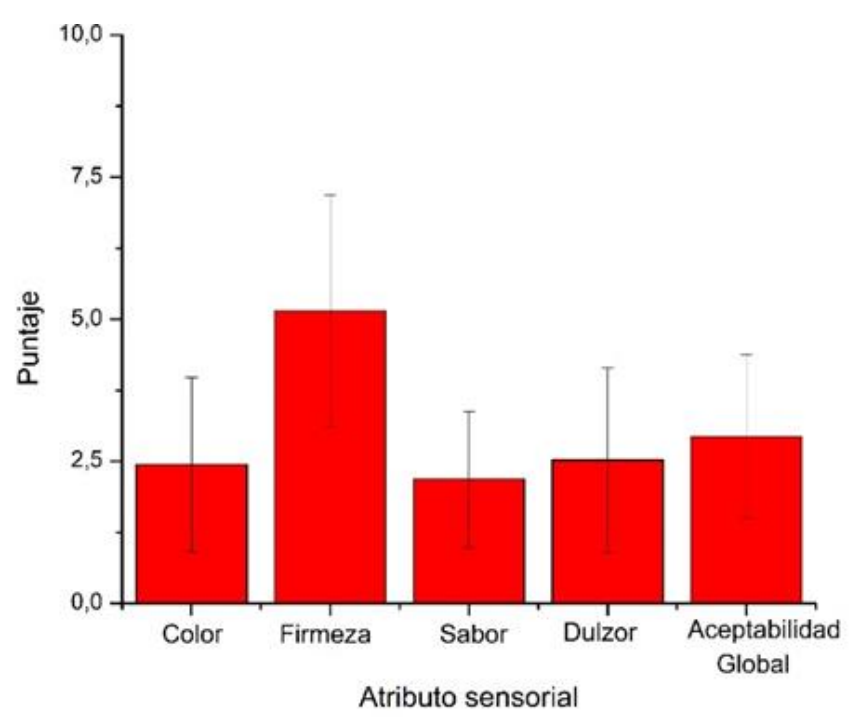

Figura 4.5. Puntajes obtenidos de los panelistas sobre los atributos sensoriales del postre elaborado a base de claro de maíz con 7\%CPL, 3\% harina de lino y $8 \%$ de miel.

La relación óptima de antioxidantes agregados a un producto y su correspondiente valor de aceptabilidad sensorial varía según el tipo de alimento. Por ejemplo, Mitsumoto y col. (2005) informaron concentraciones óptimas de catequinas entre 0,25 y $1 \% \mathrm{p} / \mathrm{v}$ para lograr una buena actividad antioxidante sobre los lípidos de empanadas de carne y pollo y una aceptable evaluación sensorial de las mismas.

Por otro lado, es posible enmascarar ciertos sabores y mejorar la percepción sensorial a través del uso de polisacáridos. Troszynska y col. (2010), estudiando un sistema modelo, encontraron resultados satisfactorios en el enmascaramiento del sabor amargo de polifenoles mediante gomas (guar, xántica y arábiga) y carboximetilcelulosa, debido a que al aumentar la viscosidad pueden modificar la percepción de astringencia y la liberación de compuestos volátiles y no volátiles. 


\subsection{CONCLUSIONES PARCIALES}

Uno de los atributos más importantes de los postres gelificados son la textura y las propiedades reológicas, por ello se analizó el aporte de cada uno de los ingredientes a las características del sistema.

El agregado de harina de lino incrementó los módulos G', G” y la viscosidad de los sistemas con claro de maíz, yerba mate y CPL. La concentración de proteína tuvo mayor contribución sobre ambos módulos, comparado con la concentración de harina de lino. En todos los casos, el módulo elástico se mantuvo por encima del módulo viscoso indicando un comportamiento predominantemente sólido en todas las muestras.

El precalentamiento de la harina de lino antes de la incorporación del CPL generó geles más rígidos, con mayor resistencia al flujo y más viscosos que los geles sin harina. Los puentes de hidrógeno y las interacciones electrostáticas entre el almidón, las gomas y las proteínas serían las principales responsables de incrementar estos valores. Durante el almacenamiento refrigerado la viscosidad compleja de los geles aumentó, siendo mayor a la máxima concentración de CPL ensayada ( $9 \% \mathrm{p} / \mathrm{p})$, seguido de los geles que contenían la harina de lino con y sin precalentamiento.

En todos los geles que contenían miel se encontraron los valores más bajos de viscosidad debido a la formación de estructuras gelificadas más débiles. La miel, si bien disminuyó los parámetros de textura de los geles, tuvo un efecto estabilizante ya que dichos valores no se modificaron significativamente durante el tiempo de almacenamiento ensayado. La capacidad de retención de agua de los geles tuvo una tendencia a aumentar con el agregado de miel pero sin diferencias significativas y se mantuvo estable durante el almacenamiento, probablemente debido a la capacidad de la miel de formar puentes de hidrógeno con moléculas de agua.

Respecto al color de los geles, el agregado de harina de lino disminuyó el color verde aportado por el extracto de yerba mate como así también la luminosidad. Por otro lado, el precalentamiento de la harina no generó cambios de color en los geles.

La composición del producto final mostró valores superiores en proteína y cenizas frente a postres comerciales del mercado con menores contenidos de lípidos y glúcidos. En cambio, el contenido de polifenoles totales disminuyó significativamente en el producto final, probablemente debido a la pérdida de estos compuestos durante los tratamientos térmicos en las diferentes etapas de elaboración, desde la obtención del claro de maíz hasta su posterior calentamiento para elaborar el postre.

El análisis sensorial del producto arrojó que la firmeza fue aceptable, aunque el dulzor obtuvo una puntuación baja, más allá de tener miel en la composición. 
Conclusiones generales 
En este trabajo de Tesis se desarrollaron dos alimentos, por un lado, un snack formulado a base de maíz con harina de lino y antioxidantes de yerba mate y, por otro, a partir del líquido de cocción del maíz, un postre gelificado con concentrado de proteínas de suero de leche, miel y harina de lino. Estas investigaciones pueden contribuir con alternativas para la producción de alimentos a base de maíz a fin de generar productos saludables que incluyan al segmento de la población celíaca, utilizando también subproductos de industrias alimentarias.

En el caso del snack se utilizaron ingredientes con alto contenido de compuestos activos, como la harina de lino (fibras, proteínas y antioxidantes) y la yerba mate (antioxidantes y minerales), para enriquecer la formulación. A través de la optimización de las condiciones del proceso de elaboración se logró un producto con características de humedad, actividad acuosa y color adecuados para un alimento tipo snack.

La evaluación del efecto de los ingredientes y de las variables de proceso sobre las propiedades reológicas y de textura del snack ayudó a la comprensión de los fenómenos que modificaron la estructura del alimento durante el almacenamiento. La capacidad de captar agua de las proteínas y de los mucilagos presentes en la fibra de la harina de lino y la retrogradación del almidón fueron los principales factores que afectaron dichas propiedades en el snack.

Además, la composición rica en proteínas, baja en glúcidos y la actividad antioxidante hallada en los snacks permitiría denominar a este alimento como saludable debido a sus potenciales efectos en el organismo. Cabe destacar que a través del análisis de prolaminas se pudo establecer que es importante la certificación de la materia prima para asegurar que no contenga prolaminas. Por otro lado, el almidón lixiviado del maíz y los contenidos de polifenoles y flavonoides del extracto de yerba mate remanentes en el líquido de cocción del maíz decidieron el uso de este subproducto para la obtención de un postre con aporte de compuestos activos beneficiosos para la salud.

En el desarrollo del postre, el concentrado proteico de lactosuero le aportó no sólo las proteínas sino también la textura de gel necesaria para este tipo de alimento. El agregado de la miel, si bien disminuyó la rigidez de los geles, contribuyó a estabilizar la estructura y a aportar el sabor dulce. Si bien la textura del postre fue moderadamente aceptable, el sabor no obtuvo buen puntaje de acuerdo con lo expresado por el panel sensorial de consumidores, atribuido al sabor astringente de la yerba mate.

Como perspectivas a futuro, tanto en el snack como en el postre, la característica del sabor debe optimizarse ya que en ambos casos se determinó que el panel esperaba un sabor salado en el snack y más dulce en el postre. Para llevar a cabo 
estas modificaciones en las formulaciones deberán tenerse en cuenta los cambios en las propiedades fisicoquímicas y de textura, como también en el almacenamiento, que pueda producir la inclusión del nuevo ingrediente en el caso de la sal o de un mayor contenido de miel. En este último caso será necesario también incrementar el contenido de las proteínas del lactosuero o de la harina de lino para equilibrar la disminución en la rigidez del gel que produce la miel. Asimismo, será importante la inclusión de un ingrediente que aporte un color atractivo al postre, como puede ser un extracto de frutas natural, contribuyendo así también al mayor aprovechamiento de recursos naturales para la formulación de nuevos alimentos. 
Bíbliografía 
- Alaedini, A., \& Green, P. H. (2005). Narrative review: celiac disease: understanding a complex autoimmune disorder. Annals of Internal Medicine, 142(4), 289-98.

- AOAC. (1997). Official methods of analysis (16th ed., 3rd revision). EE.UU.

- Ares, G., Barreiro, C., Deliza, R., Giménez, A. N. A., \& Gambaro, A. (2010). Application of a check-all-that-apply question to the development of chocolate milk desserts. Journal of Sensory Studies, 25, 67-86.

- $\quad$ Arts, M. J. T. J., Haenen, G. R. M. M., Voss, H. P., \& Bast, A. (2001). Masking of antioxidant capacity by the interaction of flavonoids with protein. Food and Chemical Toxicology, 39(8), 787-791.

- Arts, M. J., Haenen, G. R., Wilms, L. C., Beetstra, S. A., Heijnen, C. G., Voss, H. P., \& Bast, A. (2002). Interactions between flavonoids and proteins: effect on the total antioxidant capacity. Journal of Agricultural and Food Chemistry, 50(5), 1184-1187.

- Baltsavias, A., Jurgens, A., Vliet, T.V. (1997). "Factors affecting fracture properties of short dough biscuits." Journal of Texture Studies 28(2): 205-219.

- Barda, N. (2011). Análisis sensorial de los alimentos. Disponible en[http://www.biblioteca.org.ar/libros/210470.pdf]

- Bashir, S., Masud, T., \& Latif, A. (2006). Effect of flaxseed (Linum usitatissimum) on the baking properties of cakes and cookies. International Journal of Agricultural Research, 1, 496-502.

- Bastos, D. H. M., Oliveira, D. D., Matsumoto, R. T., Carvalho, P. D. O., \& Ribeiro, M. L. (2007). Yerba mate: pharmacological properties, research and biotechnology. Medicinal and Aromatic Plant Science and Biotechnology, 1(1), $37-46$

- BeMiller, J. N. (2011). Pasting, paste, and gel properties of starch-hydrocolloid combinations. Carbohydrate Polymers, 86(2), 386-423.

- Beta T y Corke H. (2004). Effect of ferulic acid and catechin on sorghum and maize starch pasting properties. Cereal Chemistry 81(3): 418-422

- Bhandari, B., D'Arcy, B., Kelly, C. (1999). Rheology and crystallization kinetics of honey: Present status. International Journal of Food Properties, 2(3), 217226.

- Boateng, J., Verghese, M., Walker, L. T., \& Ogutu, S. (2008). Effect of processing on antioxidant contents in selected dry beans (Phaseolus spp. L.). LWT-Food Science and Technology, 41(9), 1541-1547. 
- Bracesco, N., Sanchez, A. G., Contreras, V., Menini, T., \& Gugliucci, A. (2011). Recent advances on Ilex paraguariensis research: minireview. Journal of Ethnopharmacology, 136 (3), 378-384.

- Calisto Guzmán, L. A. (2009). Desarrollo de producto snack a base de materias primas no convencionales: poroto (Phaseolus vulgaris L.) y quinua (Chenopodium quinoa Wild). Tesina de Grado, Universidad de Chile.

- Capitani, M. I., Corzo-Rios, L. J., Chel-Guerrero, L. A., Betancur-Ancona, D. A., Nolasco, S. M., \& Tomás, M. C. (2015). Rheological properties of aqueous dispersions of chia (Salvia hispanica L.) mucilage. Journal of Food Engineering, 149, 70-77.

- Carunchia, M., Wang, L., \& Han, J. H. (2015). The use of antioxidants in the preservation of snack foods. En Handbook of Antioxidants for Food Preservation (pp. 447-474).

- Chandra, S., \& Gonzalez de Mejia, E. (2004). Polyphenolic compounds, antioxidant capacity, and quinone reductase activity of an aqueous extract of Ardisia compressa in comparison to mate (Ilex paraguariensis) and green (Camellia sinensis) teas. Journal of Agricultural and Food Chemistry, 52(11), 3583-3589.

- Chen, H. H., Xu, S. Y., \& Wang, Z. (2006). Gelation properties of flaxseed gum. Journal of Food Engineering, 77(2), 295-303.

- Cheftel, J.C.; Cuq, J. L. y Lorient, D. (1993). Aminoácidos, péptidos y proteínas. En "Química de los alimentos". Ed. Fennema, O. R. Acribia, España, Cap.5, Págs. 275-414.

- Chirdo, F. G., Añón, M. C., \& Fossati, C. A. (1995). Optimization of a competitive ELISA with polyclonal antibodies for quantification of prolamins in foods. Food and Agricultural Immunology, 7(4), 333-343.

- Chung, C., Degner, B., \& McClements, D. J. (2013). Creating novel food textures: modifying rheology of starch granule suspensions by cold-set whey protein gelation. LWT-Food Science and Technology, 54(2), 336-345.

- Commission International Del' Eclairage (1976). Colorimetry (2nd ed.). Vienna, Switzerland: CIE

- Cömert, E. D., \& Gökmen, V. (2018). Evolution of food antioxidants as a core topic of food science for a century. Food Research International, 105, 76-93.

- Coral, D. F. (2010). Influencia del hidróxido de calcio en las propiedades físicoquímicas del almidón de maíz (Tesis Doctoral, Universidad Nacional de Colombia-Sede Manizales). 
- Cueto, M., Porras-Saavedra, J., Farroni, A., Alamilla-Beltrán, L., Schöenlechner, R., Schleining, G., \& Buera, P. (2015). Physical and mechanical properties of maize extrudates as affected by the addition of chia and quinoa seeds and antioxidants. Journal of Food Engineering, 167, 139-146.

- De Wit, J. N., \& Fox, P. F. (1989). Developments in Dairy Chemistry, 4.

- De Wit, J., \& Hontelez-Backx, E. (1984). Functional properties of whey proteins in food systems. Zuivelzicht (Netherlands).

- Deladino L., Navarro A.S. \& Martino M.N. (2013). Carrier systems for yerba mate extract (Ilex paraguariensis) to enrich instant soups. Release mechanisms under different $\mathrm{pH}$ conditions. LWT - Food Science and Technology, 53, 163169.

- Deladino, L., Navarro, A. S., \& Martino, M. N. (2010). Microstructure of minerals and yerba mate extract co-crystallized with sucrose. Journal of Food Engineering, 96(3), 410-415.

- delmaíz.info. Disponible en http://delmaiz.info/caracteristicas/ 2019

- Deng, B., Yang, K., Zhang, Y. \& Li, Z. (2015). The effects of temperature on the germination behavior of white, yellow, red and purple maize plant seeds. Acta Physiologiae Plantarum, 37, 174

- Dinnella, C., Recchia, A., Vincenzi, S., Tuorila, H., \& Monteleone, E. (2009). Temporary modification of salivary protein profile and individual responses to repeated phenolic astringent stimuli. Chemical Senses, 35(1), 75-85.

- Donovan, M., Mulvihill, D.M. (1987a). Effects of chemical modification and sodium dodecyl sulphate binding on the thermostability of whey proteins. Irish Journal of Food Science and Technology, 11, 77-85.

- Donovan, M., \& Mulvihill, D. M. (1987b). Thermal denaturation and aggregation of whey proteins. Irish Journal of Food Science and Technology, 87-100.

- Fasano, A. (2005). Clinical presentation of celiac disease in the pediatric population. Gastroenterology, 128(4), S68-S73.

- Fedeniuk, R. W., \& Biliaderis, C. G. (1994). Composition and physicochemical properties of linseed (Linum usitatissimum L.) mucilage. Journal of Agricultural and Food Chemistry, 42(2), 240-247.

- Fennema, O. 2000. Química de los alimentos $2^{\mathrm{a}}$ ed. Acribia, Zaragoza, España.1258p.

- Figuerola, F., Muñoz, O., \& Estévez, A. M. (2008). La linaza como fuente de compuestos bioactivos para la elaboración de alimentos. Agro sur, 36(2), 4958.

- Flax Council of Canada. Disponible en http://flaxcouncil.ca/ 2017 
- Freitas, R. A., Gorin, P. A. J., Neves, J., \& Sierakowski, M. R. (2003). A rheological description of mixtures of a galactoxyloglucan with high amylose and waxy corn starches. Carbohydrate Polymers, 51(1), 25-32.

- Garcia, J., Pérez, A., Acosta, H. A., \& Castillo, H. S. V. (2006). Reología de masas de maíz reforzadas con manitol y CMC. Biotecnología en el Sector Agropecuario y Agroindustrial: BSAA, 4(1), 51-57.

- Garda, M. R., Alvarez, M. S., Lattanzio, M. B., Ferraro, C., \& Colombo, M. E. (2012). Rol de los hidrocoloides de semillas de chía y lino en la optimización de panificados libres de gluten. Diaeta (B. Aires), 30(140), 31-38.

- Gomez, J. C., Selvaggio, G. S., Viola, M., Pizarro, B., La Motta, G., De Barrio, S., \& Maurino, E. (2001). Prevalence of celiac disease in Argentina: screening of an adult population in the La Plata area. The American Journal of Gastroenterology, 96(9), 2700-2704.

- Guzmán, A. Q., Flores, M. E. J., Escobedo, R. M., Guerrero, L. C., \& Feria, J. S. (2009). Changes on the structure, consistency, physicochemical and viscoelastic properties of corn (Zea mays $s p$.) under different nixtamalization conditions. Carbohydrate Polymers, 78(4), 908-916.

- Hall III, C., Tulbek, M. C., \& Xu, Y. (2006). Flaxseed. Advances in Food and Nutrition Research, 51, 1-97.

- Heidenreich, S., Jaros, D., Rohm, H., \& Ziems, A. (2004). Relationship between water activity and crispness of extruded rice crisps. Journal of Texture Studies, 35(6), 621-633.

- Hernández-Rojas, M., \& Vélez-Ruiz, J. F. (2014). Suero de leche y su aplicación en la elaboración de alimentos funcionales. Temas selectos de ingeniería de alimentos, 8(2), 13-22.

- Hesarinejad, M. A., Jokandan, M. S., Mohammadifar, M. A., Koocheki, A., Razavi, S. M. A., Ale, M. T., \& Attar, F. R. (2018). The effects of concentration and heating-cooling rate on rheological properties of Plantago lanceolata seed mucilage. International Journal of Biological Macromolecules, 115, 1260-1266.

- Hideko P., Amaral F.F. \& Barretto A.L. (2004). Caracterizacao Tecnológica de Sobremesas Lácteas Achocolatadas Cremosas Elaboradas com Concentrado Protéico de Soro e Misturas de Gomas Carragena e Guar. Revista Brasileira de Ciencias Farmacéuticas, 40(3):397-404.

- Holser, R. A., Carriere, C. J., Park, J. S., \& Abbott, T. P. (2000). Rheological characterization of jet-cooked Lesquerella fendleri seed gum and cornstarch solutions. Industrial Crops and Products, 11(2-3), 243-247. 
- Hough, G., Wakeling, I., Mucci, A., Chambers IV, E., Gallardo, I. M., \& Alves, L. R. (2006). Number of consumers necessary for sensory acceptability tests. Food Quality and Preference, 17(6), 522-526.

- Hussain, S., Anjum, F. M., Butt, M. S., \& Sheikh, M. A. (2008). Chemical composition and functional properties of flaxseed (Linum usitatissimum) flour. Sarhad Journal of Agriculture, 24(4), 649-653.

- INYM. Instituto Nacional de la Yerba Mate. Disponible en https://www.inym.org.ar/es 2019

- Jaeger, S. R., Axten, L. G., Wohlers, M. W., \& Sun-Waterhouse, D. (2009). Polyphenol-rich beverages: insights from sensory and consumer science. Journal of the Science of Food and Agriculture, 89(14), 2356-2363.

- Kella, N. K. D., \& Kinsella, J. E. (1988). Enhanced thermodynamic stability of $\beta$ lactoglobulin at low pH. A possible mechanism. Biochemical Journal, 255(1), 113-118.

- Keri Marshall, N. D. (2004). Therapeutic applications of whey protein. Alternative Medicine Review, 9(2), 136-156.

- Khouryieh, H., \& Aramouni, F. (2012). Physical and sensory characteristics of cookies prepared with flaxseed flour. Journal of the Science of Food and Agriculture, 92(11), 2366-2372.

- Kozłowski, R. M. (Ed.). (2012). Handbook of natural fibres: Processing and applications. Ed. Elsevier.

- Labuza, T. P. (1980). The effect of water activity on reaction kinetics of food deterioration. Food Technol, 34(4), 36-41.

- Lesschaeve, I., \& Noble, A. C. (2005). Polyphenols: factors influencing their sensory properties and their effects on food and beverage preferences. The American Journal of Clinical Nutrition, 81(1), 330S-335S.

- Lionetti, E., Gatti, S., Pulvirenti, A., \& Catassi, C. (2015). Celiac disease from a global perspective. Best Practice \& Research Clinical Gastroenterology, 29(3), 365-379.

- Lipilina, E., \& Ganji, V. (2009). Incorporation of ground flaxseed into bakery products and its effect on sensory and nutritional characteristics-a pilot study. Journal of Foodservice, 20(1), 52-59.

- López Córdoba A.F., Matera S., Deladino L., Hoya A., Navarro A.S. \& Martino M. (2015). Compressed tablets based on mineral-functionalized starch and cocrystallized natural antioxidants. Journal of Food Engineering 146, 232-242. 
- López Córdoba, A.F. (2012). Desarrollo de sistemas de encapsulación compuestos para la protección de extractos antioxidantes de yerba mate (Tesis de Maestría, Facultad de Ciencias Exactas, Universidad Nacional de La Plata).

- Mäkilä, L., Laaksonen, O., Diaz, J. M. R., Vahvaselkä, M., Myllymäki, O., Lehtomäki, I., ... \& Yang, B. (2014). Exploiting blackcurrant juice press residue in extruded snacks. LWT-Food Science and Technology, 57(2), 618-627.

- Marín, P. A., De León, C., \& Acosta, H. (2011). Caracteristicas fisico-quimicas, organolepticas y reologicas de arepas procesadas a partir de maices de alta calidad proteica (QPM). Ingeniería y Competitividad, 5(1), 36-43.

- Marpalle, P., Sonawane, SK, y Arya, SS (2014). Efecto de la adición de harina de linaza sobre las propiedades fisicoquímicas y sensoriales del pan funcional. LWT-Ciencia y tecnología de los alimentos, 58 (2), 614-619.

- Martínez-Tomé, M., Murcia, M. A., Frega, N., Ruggieri, S., Jiménez, A. M., Roses, F., \& Parras, P. (2004). Evaluation of antioxidant capacity of cereal brans. Journal of Agricultural and Food Chemistry, 52(15), 4690-4699.

- Martínez, A. (2013). Microscopía confocal. Servicio de proceso de imágenes. Universidad de Oviedo.

- Marzec, A., \& Lewicki, P. P. (2006). Antiplasticization of cereal-based products by water. Part I. Extruded flat bread. Journal of Food Engineering, 73(1), 1-8.

- Mazza, G., \& Biliaderis, C. G. (1989). Functional properties of flax seed mucilage. Journal of Food Science, 54(5), 1302-1305.

- Menteş, Ö., Bakkalbaşşi, E., \& Ercan, R. (2008). Effect of the use of ground flaxseed on quality and chemical composition of bread. Food Science and Technology International, 14(4), 299-306.

- Meza, B. E. D. V. (2009). Estudio del efecto de la congelación sobre las características físicas y químicas de sistemas elaborados con proteínas del suero (Tesis Doctoral, Universidad Nacional del Litoral).

- Mintel Report. Global food and drink trends 2018. Disponible en http://www.mintel.com/mintel-reports 2018

- Mir, S. A., Bosco, S. J. D., \& Shah, M. A. (2019). Technological and nutritional properties of gluten-free snacks based on brown rice and chestnut flour. Journal of the Saudi Society of Agricultural Sciences, 1, 89-94.

- Mitsumoto, M., O'Grady, M. N., Kerry, J. P., \& Buckley, D. J. (2005). Addition of tea catechins and vitamin $\mathrm{C}$ on sensory evaluation, colour and lipid stability during chilled storage in cooked or raw beef and chicken patties. Meat Science, 69(4), 773-779. 
- Naji-Tabasi, S., \& Razavi, S. M. A. (2017). New studies on basil (Ocimum bacilicum L.) seed gum: Part III-Steady and dynamic shear rheology. Food Hydrocolloids, 67, 243-250.

- Oomah, B. D. (2001). Flaxseed as a functional food source. Journal of the Science of Food and Agriculture, 81(9), 889-894.

- Orjuela Palacio, J. M., Marino, D., Zamora, C., \& Lanari, M. C. (2014). Analisis sensorial y fisicoquimico de bebidas en polvo a base de yerba mate (Ilex Paraguariensis) y Cassis (Ribes Nigrum). En International Conference on Food Innovation.

- Oroian, M., Amariei, S., Escriche, I., \& Gutt, G. (2013). Rheological aspects of Spanish honeys. Food and Bioprocess Technology, 6(1), 228-241.

- Patrignani, M., Bernardelli, C., Conforti, P.A., Malacalza, N.H., Yamul, D.K., Donati, E., \& Lupano, C. E. (2015). Geographical discrimination of honeys through antioxidant capacity, mineral content and color. International Journal of Food Science and Technology, 50, 2598-2605. doi:10.1111/ijfs.12928

- Piazza, L., \& Masi, P. (1997). Development of crispness in cookies during baking in an industrial oven. Cereal Chemistry, 74(2), 135-140.

- Plencovich, R. P., Trouilh Zarza, D. B., \& Massari, T. N. (2017). Harina de amaranto y semillas de lino en la elaboración de scones aportando aminoácidos y ácidos grasos esenciales. Universidad Nacional de Córdoba.

- Pokorny, J., Yanishlieva, N., y Gordon, M. (2001). Antioxidants in Food Practical Applications. En Woodhead Publishing.

- Potter, R., Stojceska, V., \& Plunkett, A. (2013). The use of fruit powders in extruded snacks suitable for Children's diets. LWT-Food Science and Technology, 51(2), 537-544.

- Ptaszek, P., \& Grzesik, M. (2007). Viscoelastic properties of maize starch and guar gum gels. Journal of Food Engineering, 82(2), 227-237.

- Quéguiner, C.; Dumay, E.; Cavalier, C. y Cheftel, J. (1989). Reduction of Streptococcus thermophilus in a whey protein isolate by low moisture extrusion cooking without loss of functional properties. International Journal of Food Science and Technology, 24, 601-612.

- Ramallo, L. A., Smorczewski, M., Valdez, E. C., Paredes, A. M., \& Schmalko, M. E. (1998). Contenido nutricional del extracto acuoso de la yerba mate en tres formas diferentes de consumo. La Alimentación Latinoamericana, 225, 4852. 
- Ramcharitar, A., Badrie, N., Mattfeldt-Beman, M., Matsuo, H., \& Ridley, C. (2005). Consumer acceptability of muffins with flaxseed (Linum usitatissimum). Journal of Food Science, 70(7), s504-s507.

- Ratnayake, W. S., \& Jackson, D. S. (2006). Gelatinization and solubility of corn starch during heating in excess water: new insights. Journal of Agricultural and Food Chemistry, 54(10), 3712-3716.

- $\quad$ Re, R., Pellegrini, N., Proteggente, A., Pannala, A., Yang, M., \& Rice-Evans, C. (1999). Antioxidant activity applying an improved ABTS radical cation decolorization assay. Free Radical Biology and Medicine, 26(9-10), 1231-1237.

- Reis, S. F., \& Abu-Ghannam, N. (2014). Antioxidant capacity, arabinoxylans content and in vitro glycaemic index of cereal-based snacks incorporated with brewer's spent grain. LWT-Food Science and Technology, 55(1), 269-277.

- Rivera-Corona, J. L., Rodríguez-González, F., Rendón-Villalobos, R., GarcíaHernández, E., \& Solorza-Feria, J. (2014). Thermal, structural and rheological properties of sorghum starch with cactus mucilage addition. LWT-Food Science and Technology, 59(2), 806-812.

- Rodrigo, L., Garrote, J. A., \& Vivas, S. (2008). Enfermedad celíaca. Medicina Clínica, 131(7), 264-270.

- Rodríguez Negrette, A. C. (2016). Desarrollo y caracterización de un alimento tipo snack por secado de geles mixtos de proteínas de lactosuero y miel (Tesis de Maestría, Facultad de Ciencias Exactas, Universidad Nacional de La Plata).

- Rodríguez A.C., Torres, M.R., Navarro A.S. \& Yamul, D.K. (2017). Obtention and characterization of dried gels prepared with whey proteins, honey and hydrocolloids mixture. Journal of the Science of Food and Agriculture. DOI:10.1002/jsfa.8375.

- Rosentrater, K. A. (2006). A review of corn masa processing residues: Generation, properties, and potential utilization. Waste Management, 26(3), 284-292.

- Roudaut, G., Dacremont, C., \& Le Meste, M. (1998). Influence of water on the crispness of cereal-based foods: Acoustic, mechanical, and sensory studies. Journal of texture studies, 29(2), 199-213.

- Sáenz, C., Sepúlveda, E., Araya, E., \& Calvo, C. (1993). Colour changes in concentrated juices of prickly pear (Opuntia ficus indica) during storage at different temperatures. LWT-Food Science and Technology, 26(5), 417-421.

- Sánchez, C., Castignani, H., \& Rabaglio, M. (2018). El mercado apícola internacional. Instituto Nacional de Tecnología Agropecuaria (INTA), Ministerio de Agroindustria. 
- Sánchez-Valle, V., \& Méndez-Sánchez, N. (2018). Estrés oxidativo, antioxidantes y enfermedad. Médica Sur, 20(3), 161-168.

- Schmidt, R.H, Illingworth, BL, Ahmed, EM, y Richter, RL. (1978). The effect of dialysis on heat induced gelation of whey protein concentrate. Journal of food processing and preservation, 2(2), 111-120.

- Sarabhai, S., \& Prabhasankar, P. (2015). Influence of whey protein concentrate and potato starch on rheological properties and baking performance of Indian water chestnut flour based gluten free cookie dough. LWT-Food Science and Technology, 63(2), 1301-1308.

- Shi, X., \& BeMiller, J. N. (2002). Effects of food gums on viscosities of starch suspensions during pasting. Carbohydrate Polymers, 50(1), 7-18.

- Silva, E., Birkenhake, M., Scholten, E., Sagis, L.M.C., Van der Linden, E. (2013). Controlling rheology and structure of sweet potato starch noodles with high broccoli powder content by hydrocolloids. Food Hydrocolloids, 30, 42-52.

- Silvano, M.F; Varela, M.S; Palacio, M.A; Ruffinengo, S., \& Yamul, D.K. (2014). Physicochemical parameters and sensory properties of honeys from Buenos Aires region. Food Chemistry, 152, 500-507.

- Singleton, V. L., Orthofer, R., \& Lamuela-Raventós, R. M. (1999). Analysis of total phenols and other oxidation substrates and antioxidants by means of Folin-Ciocalteu reagent. En Methods in enzymology, 299, 152-178. Academic Press.

- Socha, R., Juszczak, L., Pietrzyk, S., Gałkowska, D., Fortuna, T., \& Witczak, T. (2011). Phenolic profile and antioxidant properties of Polish honeys. International Journal of Food Science \& Technology, 46(3), 528-534.

- Socha, R., Juszczak, L., Pietrzyk, S., \& Fortuna, T. (2009). Antioxidant activity and phenolic composition of herbhoneys. Food Chemistry, 113(2), 568-574.

- Standing, M.; Langton, M. y Hermansson, A. (1993). Microstructre and rheological behavior of $\beta$-lactoglobulin gel structures. Food Hydrocoloids, 7 , 195-212.

- Steffe, J. F. (1996). Rheological methods in food process engineering. Freeman Press.pp 1,2.

- Sun-Waterhouse, D., Teoh, A., Massarotto, C., Wibisono, R., \& Wadhwa, S. (2010). Comparative analysis of fruit-based functional snack bars. Food Chemistry, 119(4), 1369-1379.

- Tavares, C., \& da Silva, J. L. (2003). Rheology of galactomannan-whey protein mixed systems. International Dairy Journal, 13(8), 699-706. 
- Taylor, S.; Gladden L. \& Fryer, P. (1994). Changes in the gelation mechanisms of whey protein concentrate with $\mathrm{pH}$ and temperature. Journal of Dairy Research, 61, 71-81.

- Trevisan, A. J. B., \& Gomes Arêas, J. A. G. (2012). Development of corn and flaxseed snacks with high-fibre content using response surface methodology (RSM). International Journal of Food Sciences and Nutrition, 63(3), 362-367.

- Troszyńska, A., Narolewska, O., Robredo, S., Estrella, I., Hernández, T., Lamparski, G., \& Amarowicz, R. (2010). The effect of polysaccharides on the astringency induced by phenolic compounds. Food Quality and Preference, 21(5), 463-469.

- van Vliet, T., Lakemond, C. M., \& Visschers, R. W. (2004). Rheology and structure of milk protein gels. Current Opinion in Colloid \& Interface Science, 9(5), 298-304.

- Vieira, M. A., Maraschin, M., Pagliosa, C. M., Podestá, R., De Simas, K. N., Rockenbach, I. I., ... \& Amante, E. R. (2010). Phenolic acids and methylxanthines composition and antioxidant properties of mate (Ilex paraguariensis) residue. Journal of Food Science, 75(3), C280-C285.

- Vieira, M. A., Rovaris, A. A., Maraschin, M., De Simas, K. N., Pagliosa, C. M., Podestá, R., ... \& Amante, E. R. (2008). Chemical characterization of candy made of erva-mate (llex paraguariensis A. St. Hil.) residue. Journal of Agricultural and Food Chemistry, 56(12), 4637-4642.

- von Staszewski, M. (2011). Impacto de la interacción entre polifenoles de té verde y proteínas del lactosuero sobre las propiedades biológicas y funcionales de las mezclas (Tesis Doctoral, Facultad de Ciencias Exactas y Naturales, Universidad de Buenos Aires).

- Wang, Y., Wang, L. J., Li, D., Özkan, N., Chen, X. D., \& Mao, Z. H. (2008). Effect of flaxseed gum addition on rheological properties of native maize starch. Journal of Food Engineering, 89(1), 87-92.

- Watson, S. A. (1987). Structure and composition. American Association of Cereal Chemists, Inc.

- Wójtowicz, A., Mitrus, M., Oniszczuk, T., Mościcki, L., Kręcisz, M., \& Oniszczuk, A. (2015). Selected physical properties, texture and sensory characteristics of extruded breakfast cereals based on wholegrain wheat flour. Agriculture and Agricultural Science Procedia, 7, 301-308.

- Wu, M., Li, D., Wang, L. J., Özkan, N., \& Mao, Z. H. (2010). Rheological properties of extruded dispersions of flaxseed-maize blend. Journal of Food Engineering, 98(4), 480-491. 
- Wu, Y., Chen, Z., Li, X., \& Li, M. (2009). Effect of tea polyphenols on the retrogradation of rice starch. Food Research International, 42(2), 221-225.

- Wu, Y., Lin, Q., Chen, Z., \& Xiao, H. (2011). The interaction between tea polyphenols and rice starch during gelatinization. Food Science and Technology International, 17(6), 569-577.

- Yamul, D. K., \& Lupano, C. E. (2003). Properties of gels from whey protein concentrate and honey at different pHs. Food Research International, 36(1), 2533.

- Yamul, D. K., \& Lupano, C. E. (2005). Whey protein concentrate gels with honey and wheat flour. Food Research International, 38(5), 511-522.

- Yamul, D. K. (2008). Propiedades de geles de concentrado de proteínas de lactosuero, miel y harina (Tesis Doctoral, Facultad de Ciencias Exactas, Universidad Nacional de La Plata).

- Yamul, D.K.; Lupano, C.E (2009). Viscoelastic properties of whey protein concentrate gels with honey and wheat flour at different $\mathrm{pH}$. Journal of Texture Studies, 40, 319-333.

- Yu, L., Yakubov, G. E., Zeng, W., Xing, X., Stenson, J., Bulone, V., \& Stokes, J. R. (2017). Multi-layer mucilage of Plantago ovata seeds: Rheological differences arise from variations in arabinoxylan side chains. Carbohydrate Polymers, 165, 132-141.

- Yuksel, F., Karaman, S., \& Kayacier, A. (2014). Enrichment of wheat chips with omega-3 fatty acid by flaxseed addition: Textural and some physicochemical properties. Food Chemistry, 145, 910-917. 